\title{
Consecrated and Desecrated Bodies:
}

The Polemical Image of the Fetus in the Work of Gustav Mossa

by

Meredith K. Inksetter, B.A. (Hons).

A thesis submitted to the Faculty of

Graduate Studies and Research in partial fulfilment

of the requirements for the degree of

Master of Arts

in Art History

Carleton University

OTTAWA, Ontario

(C) 2008, Meredith K. Inksetter 


$\begin{array}{ll}\begin{array}{l}\text { Library and } \\ \text { Archives Canada }\end{array} & \begin{array}{l}\text { Bibliothèque et } \\ \text { Archives Canada }\end{array} \\ \begin{array}{l}\text { Published Heritage } \\ \text { Branch }\end{array} & \begin{array}{l}\text { Direction du } \\ \text { Patrimoine de l'édition }\end{array} \\ \begin{array}{l}\text { 395 Wellington Street } \\ \text { Ottawa ON K1A ON4 } \\ \text { Canada }\end{array} & \begin{array}{l}\text { 395, rue Wellington } \\ \text { Ottawa ON K1A 0N4 } \\ \text { Canada }\end{array}\end{array}$

Your file Votre référence ISBN: 978-0-494-43467-3

Our file Notre référence

ISBN: 978-0-494-43467-3

NOTICE:

The author has granted a nonexclusive license allowing Library and Archives Canada to reproduce, publish, archive, preserve, conserve, communicate to the public by telecommunication or on the Internet, loan, distribute and sell theses worldwide, for commercial or noncommercial purposes, in microform, paper, electronic and/or any other formats.

The author retains copyright ownership and moral rights in this thesis. Neither the thesis nor substantial extracts from it may be printed or otherwise reproduced without the author's permission.
AVIS:

L'auteur a accordé une licence non exclusive permettant à la Bibliothèque et Archives Canada de reproduire, publier, archiver, sauvegarder, conserver, transmettre au public par télécommunication ou par l'Internet, prêter, distribuer et vendre des thèses partout dans le monde, à des fins commerciales ou autres, sur support microforme, papier, électronique et/ou autres formats.

L'auteur conserve la propriété du droit d'auteur et des droits moraux qui protège cette thèse. $\mathrm{Ni}$ la thèse ni des extraits substantiels de celle-ci ne doivent être imprimés ou autrement reproduits sans son autorisation.
In compliance with the Canadian

Privacy Act some supporting forms may have been removed from this thesis.

While these forms may be included in the document page count, their removal does not represent any loss of content from the thesis.
Conformément à la loi canadienne sur la protection de la vie privée, quelques formulaires secondaires ont été enlevés de cette thèse.

Bien que ces formulaires aient inclus dans la pagination, il n'y aura aucun contenu manquant.

\section{Canada}




\begin{abstract}
This thesis examines the image of the fetus that appeared within three paintings from c.1905-07 by the French Symbolist artist, Gustav Adolf Mossa. These paintings - Le Système du Docteur Forceps, Le Foetus, and La Madone - reflect the historical framework of sociopolitical and religious issues that surrounded the fetus in France during the fin de siècle. At this time, the fetus was at the centre of debates surrounding the women's movement and the rise of abortion and depopulation rates, as well as concerns over degeneration and spiritual decay. This thesis references these issues in order to explore the function of the fetal motif in Mossa's art as a symbol for the borders between order and disorder, the internal and external, and the sacred and the profane. Chapter one provides an historical context for viewing Mossa's fetal imagery and chapter two then seeks to provide an in-depth analysis of the three key images in the light of this context. In the third chapter, I utilize the theoretical writings on the purification of the profane by Mary Douglas and on the abject by Julia Kristeva, as these concepts allow for an exegesis of the key images that goes beyond that reached by iconographical and historically contextual interpretations.
\end{abstract}




\section{Acknowledgements}

I wish to thank, first and foremost, my wonderful advisor, Roger Mesley, whose support, expertise and patience made this research possible. While I was enrolled in his undergraduate classes during my B.A. at Carleton, he inspired me to pursue graduate studies in art history by revealing how fascinating (and just plain fun) the study of art could be. I owe him thanks for his endless enthusiasm, kindness and meticulous editing (replete with welcomed witticisms in the margins) that made my work over the last two years a joy to undertake. I also owe my thanks to his partner, Cathy, who was always supportive and welcoming during my many visits and who enlivened our editing sessions with her presence.

I would additionally like to extend my deepest thanks to Randi Klebanoff, who has always been a source of encouragement during my time at Carleton. My research on Renaissance vessel imagery, with which she assisted me, led to my interest in the history of maternal imagery. My sincerest thanks go also to my dear friend and colleague, Susanne McColeman, who helped to verify many of the religious points within my thesis and who provided me with hours of enlightening (and often "monstrous") discussion.

I must also acknowledge the kind assistance that I received from Mme. Grimaud at the Musée des Beaux Arts (Jules Chéret) and from the Priors at the Chapelle de Saint Suaire when I was conducting my research in Nice. My travel to Nice was facilitated by a travel grant from the School for Graduate Studies and Research at Carleton University. I was also able to carry out this project as a result of funding from the Social Sciences and Humanities Research Council of Canada and from Carleton University, and for this support I am exceedingly grateful.

Finally, I wish to thank both of my parents, as well as my grandmother, Isobel, for years of unending love and support. The assistance of my Uncle Bruce and cousin Leila in translating my letters of introduction was also greatly appreciated. Thanks also to Huxley for the many long walks that helped me to clarify my thoughts. And, of course, a very special thank you must go to my fiancé, best friend and fellow prankster, Ian, who brought me innumerable cups of hot tea and read various drafts of my chapters along the way. Without his continuous patience, love and assistance, I would not have been able to complete this thesis. 
Table of Contents

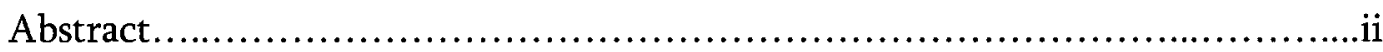

Acknowledgements...........................................................

List of Figures.....................................................................

Introduction: The Fetus in the Work of Gustav Mossa, c.1905-1907....................1

Chapter One: The Maternal and the Internal................................. 14

Chapter Two: The State of the Fetus and the State of the Nation..................42

Chapter Three: Transgressing Boundaries..................................88

Conclusion............................................................ 115

Figures............................................................ 118

Bibliography......................................................... 147 


\section{List of Figures}

1. H. Daumier, La mère est dans le feu de la composition, l'enfant est dans l'eau de la baignoire, 1844 (lithograph from bas bleus series).

2. Grandjouan, cartoon from L'Assiette au beurre, June 61908.

3. G. Mossa, Judith, 1906 (watercolour).

4. G. Mossa, Le Système du Docteur Forceps, 1905 (watercolour).

5. G. Mossa, Le Foetus, 1905 (watercolour).

6. G. Mossa. La Madone, 1907 (watercolour).

7. P. Camper, drawings showing the evolution of facial traits, 1791.

8. A. Clément, Republican France/Opening her Breasts to All the French, 1792.

9. H. Daumier, The Republic, 1848 (oil on canvas).

10. A. Paré, illustration from On Monsters and Marvels. figure of a child born with a live serpent in its back, $16^{\text {th }}$ century.

11. G. Mossa. L'Araignée, 1903 (unfinished oil painting on canvas).

12. Anon., illustration from Man-Midwifery Exposed, 1793.

13. G. Mossa. Israel, 1907 (oil on canvas).

14. G. Mossa, Les Quatres Evangelistes, 1906 (watercolour).

15. Anon., anti-Semitic postcard (German origin), late-19th century.

16. C. Léandre, Rothschild, 1898 (giclée print).

17. G. Mossa, Elle, 1906 (oil on canvas).

18. C. de Plancy, Illustration of Behemoth, 1852.

19. G. Doré, The Wandering Jew, 1852 (woodcut).

20. Banner of arms for Nice, from the Centenaire du Rattachement de Nice, 1960.

21. Collection of reliquaries and monstrance vessels from the Chapelle de la Miséricorde, Nice.

22. Lanterne de Bégon reliquary, 11th century. 
23. Tower reliquary of St. George, $14^{\text {th }}$ century.

24. Gilded copper monstrance with Madonna and Child decoration, $15^{\text {th }}$ century.

25. G. Mossa, sketches of religious vessels, 1900 (ink on paper).

26. G. Mossa, Christus, 1908 (oil on canvas).

27. M. van Oosterwyck, Vanitas Still Life, 1668 (oil on canvas).

28. Preserved fetus with beads in glass jar, late- $18^{\text {th }}$ century and hydrocephalic skeletons from the Musée Dupuytren, $19^{\text {th }}$-century.

29. G. Mossa, La Marchande d'Amour, 1905 (watercolour).

30. J. Vien, The Cupid Seller, 1763 (oil on canvas).

31. G. Mossa, Massacre of the Innocents, 1917 (watercolour).

32. Anon., Love of the Fatherland, 1793.

33. Anon., Maria Platytera, c. 1400.

34. Monstrance with Virgin, Church of the Immaculate Conception, France. 35a). Chartres Cathedral, rose window in North transept: Glorification of the Virgin, c.1235. b). Chartres, rose window in South transept: Christ Blessing, c.1221-30.

36. Exterior of the Chapelle de Saint Suaire, Nice.

37. Statue of Mater Expectationis, Chapelle de Saint Suaire, Nice, late $18^{\text {th }}$ century.

38. Photo of Mossa with wife and daughter beneath painted seraph.

39. Interior and exterior view of the Chapelle de la Miséricorde, Nice.

40. Rose windows in the Chapelle de la Miséricorde, Nice.

41. J. Miralhet, La Vierge de Miséricorde, Chapelle de la Miséricorde, Nice, c.1429.

42. J. Alberegno, Madonna of the Misericordia, c.1394.

43. F. Granacci, Our Lady of Mercy, early $16^{\text {th }}$ century.

44. O. Redon, In the Primeval Slime, 1880 (charcoal).

45. G. Mossa, Portrait Psychologique de l'Auteur, 1905 (watercolour).

46. M. Klinger, A Love: Awakening, 1887-1903 (etching/engraving). 
47. M. Klinger, A Love: Death, 1887-1903 (engraving/aquatint).

48. E. Munch, Madonna, c.1895-1902 (coloured lithograph).

49. G. Bernini, Ecstasy of Saint Teresa, 1652 (marble).

50. G. Mossa, Et Ne Nos Inducas in Tentationem, 1906 (watercolour). 


\section{INTRODUCTION}

The Fetus in the Work of Gustav Mossa, c.1905-1907

\section{Artiste je le suis, veux l'être, et c'est mon droit!... $A$ mon Pays je dois, avant tout, mon talent! -Gustav Mossal}

The image of the fetus emerged as a relatively new motif - often floating within glass jars or lurking on the edges of the picture plane - within fin-de-siècle art in Europe, as a number of Symbolist artists (including Gustav Mossa, Edvard Munch, Aubrey Beardsley, Odilon Redon and Max Klinger) incorporated fetal imagery within their work. This appearance of the fetus corresponded with growing social, medical and religious debates on subjects of abortion, motherhood and morality. These debates were particularly fervent in France, as the once-powerful country faced the aftermath of its defeat in the Franco-Prussian war of 1870-71 and the corresponding threat of depopulation, as well as a shifting social framework propelled by the modern rise of feminism and widespread concerns over cultural decadence. The image of the fetus became, in many ways, the unlikely keystone of this social edifice, as it represented the basic duty of the French mother at a time of national instability and assumed the symbolic role of a threatened "unborn hope" for life, order and strength within the shaken country of France.

\footnotetext{
${ }^{1}$ These lines appear in a WWI-era poem written by Gustav Mossa as part of a collection of patriotic verses entitled Songe de Noël.
} 
The appearance of the fetus within the art of the fin de siècle also stemmed from its increased visibility within public spaces of medical display and its presence within the widely disseminated, moralizing writings on the family put forth by the growing pro-natalist and antifeminist movements within France. The focus of this thesis - a group of paintings consisting of Le Système du Docteur Forceps, Le Foetus, and La Madone, c. 1905-07 by the Nice-born Symbolist artist, Gustav Adolf Mossa (1883-1971) - illustrates the many nuances found within this spectrum of influence. His works are squarely situated within the matrix of historical issues surrounding the mother and the fetus, and they additionally point to more abstract preoccupations with the intangible boundaries that separate flesh and spirit, life and death, and the sacred and the profane. This thesis will endeavour to consider these different historical and theoretical facets over the course of the ensuing chapters.

Within Mossa's rather short-lived artistic career, which spanned only 1903 to 1918, his oeuvre reveals recurring images of both fetuses and infants, as well as various representations of maternal, pregnant and overtly sexual women. His persistent treatment of maternal and fetal themes bespeaks an interest in drawing upon the tradition of mother and child imagery in order to address fundamental issues of morality. His work raises many questions surrounding the social position that was occupied by the mother, as well as the role that was played by the fetus within religious and patriotic contexts. These questions constitute the organizing principle for this thesis. 
Mossa's paintings emerge within the movements of Art Nouveau and Symbolism, wherein an artistic preoccupation with the femme nouvelle - the New Woman - was common. The image of the New Woman was linked with the growing women's movement and a reshaping of gendered positions within society. Women were often depicted engaging in forms of masculine activity, such as riding bicycles, smoking and generally neglecting their duty to husband and family. This threat to gendered order met with a wide range of opposition. Within Symbolist and Art Nouveau art of the fin de siècle, the figure of the threatening femme fatale-typified by the monstrous Amazon woman - was closely linked with a reaction to the modern female threat. In 1901, Marius-Ary Leblond described the New Woman in his treatise on "Les Peintres de la Femme Nouvelle" as follows:

We find her in the salons, this New Woman...she lives a full life, a complete and powerful one, equal in intensity and output to that of a man...These modern amazons are ferociously independent beings...driven by an eternal motion, like fantastic automobiles. ${ }^{2}$

The New Woman was thus construed as a modern force, capable of usurping male power within society.

Although the stereotype of the New Woman did not surface in France until the final decades of the nineteenth century, the first signs of the women's movement had materialized in France decades earlier. At the time of the French Revolution of 1848, for example, the artist and caricaturist, Honoré Daumier had already produced

\footnotetext{
2 Quoted in Silverman, “Nature, Nobility, and Neurology," 129. She cites Marius-Ary Leblond, "Les Peintres de la Femme Nouvelle," La Revue 39 (1901): 275-276, 289-290.
} 
satirical images of women that reflected the rise of feminist activities. A lithograph from his bas bleus series which was published in Le Charivari in 1844, for instance, depicted a neglectful femme de lettres whose child drowns in a tub of water while she is busily writing at her desk (fig.1). ${ }^{3}$

Underpinning this type of imagery was a desire to restore the gendered structures that had been shifted by the emergence of feminism. With the appearance of Art Nouveau at the end of the nineteenth century, the concern over gendered structures persisted. Following the 1889 World Exposition in Paris, the Art Nouveau movement sought to establish a new vision of modern France through dynamic wrought iron works, such as the Eiffel Tower. After 1900, this modern vision was incorporated with the feminine, curvilinear and organic forms of the decorative arts, as it ultimately became a symbol for the feminized interior of the home at a time when the domestic interior was threatened by modernity - and specifically, by the modern woman. In this way, the Art Nouveau movement reflected an interest in containing and interiorizing the feminine principle, which would effectively serve, as Debora Silverman has suggested, to symbolically restore "the boundaries between public and private, home and work, that were loosened by the emergence of the New

\footnotetext{
${ }^{3}$ Daumier, Intellectuelles (bas bleus) et femmes socialistes, 31 . The bas bleus (bluestockings) were a society of women with literary and intellectual interests and the term bas bleus came to have negative associations with unbecoming female behaviour among antifeminist supporters.
} 
Woman". ${ }^{4}$ The Art Nouveau style therefore sought to capture the ideal of the decorative woman within the domestic interior, as an antidote to the New Woman who had moved away from her proper place within the home.

Mossa's work reveals a close engagement with these ideas, as his oeuvre is filled with curvilinear, organic designs and feminine subjects, as well as depictions of the threatening femme fatale and the threatened male figure. His female figures typically have voluminous mounds of hair and are dressed in massive hats and billowing, full dresses that seem capable of engulfing their male victims. Although Mossa's images of women exaggerated the popular styles of fashion, fin-de-siècle women did in fact wear full dresses with hoop skirts, crinolines and bustles, as well as large hats and Pompadour frames to give their hair an appearance of tremendous volume. These fashions were commonly illustrated within satirical political journals of the period, such as Le Sifflet and Le Charivari. An antifeminist drawing, published in the French satirical journal, L'Assiette au beurre in 1908 (fig.2), for example, shows the New Woman wearing these "bulky fashions" as she engages in political debate. ${ }^{5}$ In her examination of the fashions of the late-nineteenth century, Bonnie Smith has argued that women's dresses served to bolster feminine power by making women appear to have a greater physical presence. Although Smith also notes that these styles ultimately served to physically imprison women under mounds of constraining

\footnotetext{
${ }^{4}$ Silverman, "Nature, Nobility, and Neurology,"127.

${ }^{5}$ Mossa would have certainly been aware of the Assiette au beurre journal, as it enjoyed considerable popularity at the time when Mossa was painting.
} 
fabric, in the eyes of Mossa and many other antifeminist artists, the mass of garments worn by female figures clearly contributed to their looming presence. ${ }^{6}$

This is evident, for example, in Mossa's 1906 image of Judith (fig.3) wherein he depicts the modern femme fatale in a colossal black hat, as she places the diminutive head of Holofernes within a small handbag. This image of the destructive modern woman draws from the ancient parable of Judith to illustrate the terrible modern threat to masculinity, as Holofernes is emasculated, fragmented (and castrated, in effect) at the hands of the powerful New Woman. This theme pervades Mossa's work, particularly because the figure of the modern woman - and the modern mother represented a key premise within his oeuvre.

While the figure of the destructive woman did not emerge as an altogether new image at the turn of the twentieth century, the specific nuances and connotations of her image in relation to the cultural climate of the fin de siècle may nonetheless be understood in new terms. With her potential ability to occupy either the proper role of the nurturing and fecund mother to the new generation of French citizens, or to refuse this role in favour of selfish pleasures and individualistic pursuits, the modern woman posed a significant threat to the greater health and wellbeing of the nation.

In his watercolour painting of 1905, Le Système du Docteur Forceps (fig.4), Mossa depicts a scene that suggests at first glance a medical visitation involving a

${ }^{6}$ Smith, Ladies of the Leisure Class, 79-90. 
female, bedridden patient and a seemingly Jewish male doctor, clothed in skulls and bones. The doctor smokes a cigar and the unfurling cloud of smoke assumes the shape of a mass of fetal bodies. Because the doctor's name - "Doctor Forceps" - suggests that the nature of his visit concerns the woman's pregnancy, the deathly elements within the scene (including the ghostly, floating fetuses and the morbid attire of the doctor) bespeak a fatal outcome for the unborn child of the female patient. The doctor's role within this scene thus foretells death rather than life and suggests that he is in fact an abortionist. The stereotypical Semitic features of the abortionist-doctor also raise questions about the racial and religious implications of this image.

The female patient sits upright in bed with a rather ambivalent demeanour, as her gaze seems to reveal ennui, apprehension or even covertness as she peers from beneath a large mound of hair. Her presence within this scene of abortion effectively begs the question of whether she is an innocent or guilty mother: whether she is victimized or complicit. How does her figure relate to the ideas of motherhood, childbirth and abortion that were prevalent within France at the time of Mossa's painting? Moreover, what is the wider significance of the highly feminine, fashionable and symbolic space that Mossa creates for this "system" of Doctor Forceps? And what, indeed, is the "system"? These are some of the questions that this analysis proposes to address.

In his watercolour painting, Le Foetus of 1905 (fig.5), Mossa presents a complementary pendant for the narrative found in Le Système du Docteur Forceps, as 
here the scene reveals a centrally displayed fetus, floating within an ornate vessel. The image thus suggests the outcome of the abortion implied by Le Système du Docteur Forceps, as here the indifferent couple displays the morbid result of the woman's abortion within their home, like a form of interior decoration. How, I propose to consider, does Mossa's depiction of the displayed fetus then engage with the issues of family and society that were present in fin-de-siècle France?

Finally, in his 1907 watercolour painting, La Madone (fig.6) - the third central image of this thesis - Mossa turns to a more overtly religious, benevolent and conventional vision of motherhood as a counterbalance for both Le Système du Docteur Forceps and Le Foetus. Here, a fetal figure appears again, although unlike the ghostly or deathly figures found in his previous images, in La Madone the fetus appears alive and growing within the womb of the ideal mother: the Virgin Mary.

Is there an historical narrative, then, that links these three images together? I will argue that Mossa's work raises many questions surrounding the role of motherhood and the fetus within French society, as his images touch on a range of both timely and timeless themes that hinge on philosophical, theological and theoretical questions of display, vision and the body.

Despite the complexities of his work and the historical relevance of his subjects, as a Symbolist working at the tail-end of the movement, Mossa has received relatively little attention within the field of art history. His artistic career (spanning roughly 1903 through 1918) was also remarkably brief, as he ceased to produce art at 
a time when his exhibitions were only just beginning both to receive critical acclaim and to be shown within the Parisian Salons after several years of mediocre reviews.

The latter half of his life was spent working as an illustrator and curator, and as such, he has often been relegated to the domain of illustrator rather than artist, and the innovative work of his early years has been widely ignored as a consequence. ${ }^{7}$

Jean-Roger Soubiran wrote the only major text devoted to Mossa in 1985. His research on Mossa began in the 1970s in conjunction with a retrospective exhibition titled, "Gustav Adolf Mossa et les Symboles” of 1978, intended to redress an absence of historical interest in Mossa's work. ${ }^{8}$ Slimmer exhibition catalogues have been produced as well by historians such as Jean Forneris, Sylvie Lafon and Anne-Marie Clais. ${ }^{9}$ Soubiran's text, however, remains the most thorough treatment of Mossa's

\footnotetext{
${ }^{7}$ Soubiran, Gustav Adolf Mossa 1883-1971, 19-22, 58, 90-126. The author notes that from 1911-1914, Mossa had begun to receive notable recognition for his work from an international audience, following Parisian press articles on his work. His first notable exhibition was in 1911, in the Galerie Georges Petit, a Symbolist art gallery in Paris. Prior to this, Mossa's work had been poorly received by critics, as they had largely found his work to be pretentious or naïve. His sudden break with art following years of prolific artistic production came after a series of events that transpired over the years of 1914-1919; namely, his involvement with WWI (wherein he sustained a serious head injury while fighting within the seventh battalion of the chasseurs alpins), as well as his separation from his first wife, CharlotteAndrée Naudin (who had also been his frequent model and muse) in 1918, and the devastating death of his mother, Marguerite in 1919. It is difficult to identify any one of these events as the primary source for his seeming disillusionment with art, for Mossa ultimately did not (to the best of our knowledge) record the personal motivations that lead to his shift in career. His final two series were rather dark reflections on the war, entitled Les Songeries de la Guerre in 1915-1916 and Visions de Guerre in 19171918. After the completion of these series, Mossa did not return to producing paintings as he had previously done; instead, he turned to illustration and began to work on projects within the theatre. In 1927, he assumed the curatorial position that his father had once held, as the Conservateur du Musée des Beaux Arts in Nice.

${ }^{8}$ Soubiran's exhibition catalogue was titled Gustav Adolf Mossa et les symboles: $1883-1971$ (Nice: La Galerie des Ponchettes, 1978).

${ }^{9}$ Forneris, Gustav Adolf Mossa: I'ceuvre symboliste 1903-1918, and Lafon and Clais, Gustav Adolf Mossa: La scène symboliste.
} 
work to date, although some current and forthcoming scholarship bespeaks renewed

interest in his work. ${ }^{10}$ Furthermore, there is a general lack of archival information on Mossa, resulting largely from the public sale of Mossa's library and archives after his death, which dispersed many of his early writings. Curiously enough, Mossa was also instrumental in suppressing his own work from the public after the exhibition of his final war series. ${ }^{11}$

Soubiran notes that Mossa's third wife, Mme. Violette Mossa, preserved a selection of press articles and various poetic and dramatic writings from his later years, but the vast majority of his early correspondence and professional writing has ultimately been lost (with the exception of his letters to his first wife, CharlotteAndrée, and his friend, Léon Ponzio). Despite the relative lack of archival material, the surviving letters are, in fact, revealing for the purpose of this thesis, as they date from roughly 1904-1908 - the period in which he produced Le Système du Docteur Forceps, Le Foetus and La Madone. ${ }^{12}$

\footnotetext{
${ }^{10}$ There have been recent exhibitions of Mossa's paintings in France, including one held in Evian in 2008, titled Eros et Thanatos dans l'oeuvre symboliste de Gustav-Adolf Mossa (curated by Mme. Yolita Rene). In addition, a forthcoming catalogue raisonné of his work is being assembled by the Association Mossa in Nice (which is headed by Mossa's grandchildren). Mossa also figures (albeit briefly) in the work of some recent historians (including Mireille Dottin-Orsini and Elizabeth Menon) whose work is concerned with representations of women within the artistic traditions of fin de siècle France. ${ }^{11}$ This fact was confirmed by the curator, Mme. Grimaud, at the Musée des Beaux Arts (Jules Chéret) in Nice. Others, such as M. Soubiran and Mme. Rene have also noted Mossa's desire to keep his paintings hidden away. As a result of this, his work was only rediscovered after the artist's death in 1971. There is little evidence to provide a concise reason for Mossa's desire to suppress his artwork, but it is possible that the traumatic events that occurred in his life between 1914 and 1919 may have affected his former ideals and taken a toll on his creative interests.

${ }^{12}$ There is little in the way of archival material from the period before his first marriage and, as Mossa was not known to have had a journal, little exists in the way of the artist's own words with regard to
} 
Soubiran's monograph attempts, in large part, to piece together a succinct and thoroughly-illustrated, historical narrative from the archival fragments of letters and primary documents that shed light on Mossa's life and artistic career. His research reveals much about Mossa's biography: his artistic training, professional career, and his family. He addresses the entire span of Mossa's oeuvre, expounding on the overarching themes, prominent symbols and major artistic influences within his work. In this, however, Soubiran's comments on specific works necessarily tend to be very cursory, as his broad approach limits the depth of interpretive discussion that can be effectively undertaken. As such, Soubiran's work opens the door (so to speak) for a more focused inquiry. This thesis, therefore, aims to expand upon the mainly factual and biographical research of Soubiran by examining in much greater detail and depth a small selection of Mossa's paintings, especially in light of their sociopolitical and theoretical implications.

The first chapter of this thesis, entitled The Maternal and the Internal, examines the interrelated matrix of social, medical and moral issues that framed the image of the fetus at the end of the nineteenth century. Mossa's fetal images touch upon a wide range of historical subjects involving the family and motherhood, morality, nationhood and depopulation, childbirth, fetal abnormality and medical displays, abortion and feminism, religious issues that surrounded Catholicism in 
France, and concerns over cultural decay. As such, chapter one attempts to address this plethora of issues generally in order in chapter two to address more thoroughly the complexities of Mossa's work..$^{13}$

After establishing the historical parameters of this thesis in chapter one, chapter two - The State of the Fetus and the State of the Nation - expands on the discussions of chapter one by examining the specific symbolic functions of Le Système du Docteur Forceps, Le Foetus and La Madone in relation to the aforementioned matrix of social issues in fin-de-siècle France. This chapter also addresses the overarching themes of morality that were entwined with the redemptive and sinful site of the mother's body and addresses more fully the presence of anti-Semitism and Catholic doctrine within Mossa's oeuvre, stemming from the arguments of chapter one.

Finally, in chapter three, entitled Transgressing Boundaries, I move to consider Mossa's images within a more theoretical framework that centres on the inherently liminal, immaterial and impermanent characteristics of the fetal body within his work. Here, I will address the shifting nature of the corporeal, social and

\footnotetext{
${ }^{13}$ With the growing academic interest in marginal areas of visual culture, several historians (including Rebecca Kukla, Barbara Stafford, Elizabeth Menon, Angus McLaren, Lianne McTavish and Adrian Wilson) have offered very thorough and insightful examinations of the philosophical, medical and social history of the issues surrounding childbirth, female fertility and the maternal body. The work of many of these historians owes a natural debt to the theories of Michel Foucault and his critical approach to the ideologies governing various social institutions and spaces that emerged in the early nineteenth century, such as the medical clinic. My examination of the historical case of the mother and fetus during the fin de siècle thus draws upon the work of these authors and necessarily utilizes aspects of Foucault's theories.
} 
sacred boundaries that framed Mossa's representation of the fetus. This chapter draws from Mary Douglas' text, Purity and Danger, wherein she explores the concept of the sacred in relation to cultural rituals of separation and the defilement of boundaries. The feminist approach of Julia Kristeva in Powers of Horror to themes of abjection and the rupture of bodily borders, additionally, offers another means of broadening the implications of Mossa's imagery. For, despite the staunchly antifeminist message of Mossa's work (which will be made clear in chapter two), Kristeva's theory offers an insightful way of understanding the boundaries that delineate social, physical and sacred transgression within Mossa's representation of the fetus. I aim to situate these concepts of transgression in relation to the thematic framework of chapters one and two, as I would suggest that the social complexities that underpin the image of the fetus inform its larger theoretical implications.

This analysis, then, seeks to consider through interdisciplinary means the work of an artist who has received relatively little scholarly attention and whose symbolic use of the fetus presents a fascinating glimpse into French fin-de-siècle thought. Moreover, his images shed light on the way in which the visual, moral and ideological systems that encompassed motherhood and nationhood in France interacted. 


\section{CHAPTER ONE}

The Maternal and the Internal:

Morality and the Decaying Family in Fin-de-Siècle France

Mossa's three paintings - Le Système du Docteur Forceps, Le Foetus, and La Madone-illustrate a close engagement with the moral state of motherhood and the family in France at the turn of the twentieth century. At this time, images of both the mother and the fetus were entwined with the political and religious climate of the period. These images were also rooted in the increasingly invasive and spectacular medical spaces that had emerged during the nineteenth century. In the introduction, it was suggested that the fetal and maternal bodies in Mossa's work reveal a complex interaction with the social milieu of France, circa 1905. As such, this chapter will primarily seek to establish a wider contextual framework for viewing these images. While the role of both the mother and the fetus as symbolic artistic motifs will be explored at greater length in chapter two, here the issues surrounding their cultural meaning within France will be examined.

The first half of this chapter looks at the broader framework of moral philosophy that has surrounded the primordial state of motherhood and the interior of the maternal womb. This leads me to a discussion of the moral values that were inscribed upon both the exterior and interior of the body in the nineteenth century amid growing fears of social decline and degeneration. The second half of this chapter will then look more closely at the specific historical issues that surrounded 
the mother and fetus in fin-de-siècle France, wherein key political concerns centred on matters of family, childbirth and abortion. This discussion examines the changing role of the French mother as the professed basis for the destruction of the family - the impending consequence of a dangerous tripartite threat in the form of depopulation, feminism and abortion. In this respect, maternal dereliction represented a very real danger to national and spiritual order - a view which was prominent within fin-desiècle France and which furthermore illustrates the premise from which Mossa's work derives. In turn, the image of the fetus, as a symbol inextricably entwined with the body of both the good and bad mother, thus hinged on the boundaries between civic order and disorder, and the sacred and the profane.

The body of the mother has long been the subject of moralizing narrative and philosophy, and the womb's innate capacity to give birth - to produce and control new life - linked the mother's body with the moral state of the population. An enduring tradition of social anxiety has existed concerning what might be termed forms of "abnormal birth" (be it the physically- or morally-deformed offspring that were often believed to result from corrupt relationships, or an absence of surviving offspring altogether - the suspected result of illicit practices such as abortion or infanticide). Cases of abnormal birth have therefore been long regarded as an indication of deep-seated corruption. 
The preoccupation with abnormal birth in the nineteenth century stemmed from a long and complex history of religious and medical ideology and ingrained social anxiety surrounding the mysterious inner workings of the generative female body. Morally-tinged discussions of the maternal womb and the nature of female sexuality can be traced back to early thinkers such as Hippocrates, Plato and Aristotle, thus illustrating the longevity and persistence of belief in the morally-encoded maternal body.

In Hippocrates' ancient medical writings on the ailments of women, for example, he first introduced the notion of the "wandering" movements of the displaced womb that would later find its way into the theories of Jean-Martin Charcot and Sigmund Freud on the disorderly body of the female hysteric. ${ }^{14}$ In Plato's Timaeus, he draws upon the Hippocratic conception of the womb and suggests that it was in fact a "living entity" that existed within the body of the woman, possessing its own voracious desire to bear children. If these desires were not realized, Plato suggests that the womb would cause great distress to the rest of the body by "straying" from its original location. ${ }^{15}$ In his History of Animals, Aristotle speculated in the same way on the various distempers of the highly corruptible and permeable womb, attributing to it similar movements and susceptibilities. ${ }^{16}$

\footnotetext{
${ }^{14}$ Hanson, "Hippocrates: Diseases of Women I," 1:573-576.

${ }^{15}$ Plato Timaeus 91.

${ }^{16}$ Aristotle History of Animals book VII, 2.
} 
Such longstanding anxieties surrounding the corrupt appetites and movements of the womb abounded throughout the coming centuries, particularly amid the spread of venereal diseases in Europe, as some medical discourses maintained that the uterus of the sexually impure woman in fact desired to feed upon the male seed and consume the penis. ${ }^{17}$ The female womb had thus long possessed a perceived ability to usurp male power and bring about physical and social corruption; especially in cases of sexual transgression or inverted gender roles. Many of these ancient concerns over the vulnerability of the male at the hands of the maternal woman lasted through the nineteenth century, as preoccupations with the womb began to reflect the new social anxieties over the politics of birth and the changing face of the family.

During the nineteenth century, female bodies in general and maternal bodies in particular were clearly defined and encoded by the ideological systems that informed visuality. The rise of modernity within the nineteenth century ultimately represented a time of drastic social and visual change, wherein the mother's body became an increasingly monitored and observed site. These changes were propelled, in many ways, by the shifting position of the mother within medical and scientific spaces that were shaped by newly emerging visual technologies, such as the $\mathrm{X}$-ray and the photographic camera, as well as advancing microscopic technologies (such as the

\footnotetext{
${ }^{17}$ See Laqueur, Making Sex, 25-62. Laqueur offers a helpful examination of the history of the womb and its "appetites" wherein he notes the persistence of ancient medical anxieties surrounding the destructive womb and the threatening vagina dentata in the nineteenth century.
} 
photomicroscope). ${ }^{18}$ These technologies enabled a new depth of vision; one that was increasingly concerned with probing the interior of the body and making visible the once-invisible realms of reality. Knowledge of the mother within fin-de-siècle society thus related directly to the very nature of visuality during this period. ${ }^{19}$

Prior to the late-eighteenth century, the most defining moment of motherhood - childbirth - had been relegated to the secretive, intimate and curtained-off realm of female midwives and female attendants - a domestic space of female ritual to which men were generally denied entry. The moment that defined, in many respects, the very essence of motherhood and womanhood, had remained for many centuries a source of great mystery and at times unease within male spheres. As a result, midwives had been widely viewed with suspicion due to the knowledge that they possessed surrounding childbirth. ${ }^{20}$ The tradition of the secretive, concealed and private maternal body of the birthing chamber, however, changed considerably over the course of a couple of decades as it became, by the early nineteenth century, increasingly positioned within the male realm of professional obstetrical physicians,

\footnotetext{
${ }^{18}$ See Kemp, "A Perfect and Faithful Record," 106-107, 112-113. The X-ray had been invented in 1895 by Wilhelm Conrad Röntgen and the first permanent photographs appeared after Joseph Niépce improved upon existing camera obscura technology in 1826. The microscope, although having been in existence since the Renaissance, was not significantly improved until the mid-nineteenth-century innovations of Charles Spencer.

${ }^{19}$ See Crary, Techniques of the Observer. Crary discusses the profound shifts that occurred within nineteenth-century visuality as a result of these technological innovations.

${ }^{20}$ Riddle, Eve's Herbs, 115-118. Riddle notes that many of the anxieties surrounding the midwife were linked with her potentially destructive knowledge of medicinal plants and herbs. There is a long tradition, dating back to the Middle Ages, of equating the midwife with witchcraft, particularly in her ability to abort children through the use of poisonous potions. The negative view of the female midwife grew as male physicians became more prominent within the field of obstetrics, as they were increasingly cast as dangerous or incompetent practitioners.
} 
examining tables, medical textbooks, public hospital spaces and new medical tools (such as the forceps) designed to enter, probe and view the once-forbidden interior cavity of the maternal body. ${ }^{21}$

This shift has been linked by several historians to the general nineteenthcentury movement away from the private realm, towards a more public, institutionalized and "self-regulating" society. This shift also marked a movement away from the reigning sense of modesty and propriety that had previously denied men the ability to be involved with childbirth, towards a system wherein, as various historians have suggested, the male doctor had considerably more authority and control over the mother's body (and as a consequence, over her behaviour as well). The new position of the maternal body within masculine medical spaces, however, was not readily accepted by all (despite acquiring a degree of fashionable prestige within upper-class circles, due to the more expensive fees of the male physician). Some mothers and midwives, in fact, resisted the perceived intrusion of the male obstetrician and refused the use of new medical instruments during the delivery process. ${ }^{22}$ Despite such resistance, the "opening up" of the maternal body to a wider audience of male onlookers effectively created new ways of envisioning and

\footnotetext{
${ }^{21}$ For more on the private-to-public shift within the domain of childbirth, see Oakley, The Captured Womb; McTavish, Childbirth and the Displays of Authority in Early Modern France, and Wilson, The Making of Man-Midwifery.

${ }^{22}$ Wilson, The Making of Man-Midwifery, 191-92.
} 
scrutinizing the mother, as the once private nature of the maternal body became, by the early nineteenth century, a new site of public viewing and increased surveillance.

The movement away from female-private spaces to male-public spaces of medical viewing has occupied a central role in the work of Michel Foucault, who, in his seminal text The Birth of the Clinic (1963), examined the shifting nature of visuality in relation to the human body within late-eighteenth- and early-nineteenthcentury medical and scientific spaces. He argues that new systems of surveillance, power and control over the pathological or abnormal body were implemented in the late-eighteenth century through the emergence of the public clinic or hospital. In such spaces of authoritative and disciplining control over the body, the subject, according to Foucault, was rendered an object before the "clinical" or "observing" gaze. ${ }^{23}$ Means of monitoring (and thus controlling) maternal bodies within the male domain of medical science during the nineteenth century included the emergence of lying-in hospitals, medical and popular writings on proper maternal behaviour, public displays of medical specimens and abnormalities, and the proliferation of an increasingly visible interior of the womb. ${ }^{24}$ As such, Mossa's depictions of both Doctor Forceps approaching the maternal subject (surrounded by male onlookers) and the overtly displayed fetal body in Le Foetus and La Madone are evocative of this "new visibility" of the mother.

\footnotetext{
${ }^{23}$ Foucault, The Birth of the Clinic. Foucault has also addressed the eighteenth-century shift from public-to-private viewing of the criminal body in Discipline and Punish.

${ }^{24}$ Oakley, The Captured Womb, 20- 42.
} 
Much of Foucault's writing has specifically addressed the systems of knowledge that defined typologies of physical normality and abnormality (and which carried with them underlying moral implications) through public spaces of display and social regulation. In The Birth of the Clinic, he describes the "blending" (so to speak) of the medical with the moral that resulted from the newly politicized role of the physician within the public space of the hospital. Whereas the physician of previous centuries would have been primarily concerned with issues of private health and matters of the physical body, Foucault argues that at the turn of the nineteenth century, there emerged a new ideal of the benevolent doctor who was devoted to the public body and who was increasingly concerned with the greater physical and moral welfare of the state. According to Foucault:

Instead of remaining what it was, 'the dry, sorry analysis of millions of infirmities', the dubious negation of the negative, [medicine] was given the splendid task of establishing in men's lives the positive role of health, virtue, and happiness...In the ordering of human existence it assumes a normative posture, which authorizes it not only to distribute advice as to healthy life, but also to dictate the standards for physical and moral relations of the individual and of the society in which he lives. ${ }^{25}$

In other words, medicine became a practice that was increasingly concerned with moral and social ordering in the nineteenth century, and which was increasingly interested in what lay beyond the superficial exterior, in the body's physical and moral interior.

\footnotetext{
${ }^{25}$ Foucault, The Birth of the Clinic, 34.
} 
Nowhere was this interest in uncovering the links between the interior and exterior of the body more apparent than in nineteenth-century scientific theories of physiognomy. ${ }^{26}$ The objective of these theories lay in classifying the physiognomies of what were believed to be morally-, racially- and socially-degenerate groups (including Jews, Africans, prostitutes, criminals, homosexuals, and the insane), as these groups represented a professed threat to both family and nation.

Physiognomical theories sought to reveal the external, physical signs of an internal, moral corruption, thus articulating the perceived symbiotic relationship between inner morality and physical appearance - which was, in turn, believed to reveal a larger condition of social degeneration. ${ }^{27}$

In essence, physiognomy - like other practices of phrenology or craniology from the period - sought to confirm the inherent, biological and scientific superiority of the European male over the alleged threatening social other (be it the "sexuallydepraved" modern woman or the "bestial" African or Jew). These classification systems involved the identification of certain degenerative traits, such as facial asymmetry, a low, receding forehead or a projecting, muzzle-like jaw, among other

\footnotetext{
${ }^{26}$ These fields of scientific study (which are viewed as obsolete examples of pseudoscience by today's standards) included not only physiognomy, but also characterology, phrenology and craniology (which were more specifically concerned with reading character through the shape of the head).

${ }^{27}$ Foucault's work on the respective histories of madness, sexuality, criminality and illness was specifically concerned with addressing the institutions of power that defined and regulated groups of social others.
} 
things. ${ }^{28}$ In a text on the study of characterology from the early twentieth century,

for example, L. Hamilton McCormick notes that these degenerative traits are "common among native African, Australian and other uncivilized races and are occasionally present in the lower classes of Europe and America". ${ }^{29}$ The ideal physiognomy, conversely, was to be found in the European male, who embodied the Greek paradigm of masculine beauty and physical strength - one which also indicated moral fortitude and intelligence. In essence, these practices bespoke a desire to preserve racial purity and separate otherness, as they juxtaposed (white) European beauty with non-European ugliness.

This ideal of masculinity is captured, for example, in the illustrations of evolving skull shapes (ranging from primitive, simian origins to the Greek ideal), drawn by the Dutch anatomist, Petrus Camper in 1821 (fig.7). The ideal man symbolized by European features and masculine strength - ultimately stood for an ideal society and nation, while the inverted masculine ideal symbolized corrupted and disorderly nationhood. In his historical examination of masculinity, George Mosse suggests that in the Enlightenment, "the joining of the outward to the inward projected a stereotype that took in the whole personality, and through the shape of

\footnotetext{
${ }^{28}$ The shape of the forehead, jaw and face are discussed by a wide range of phrenologists from the latenineteenth century and early-twentieth century. One of the first to address this subject was Dr. Johann Caspar Lavater in Essays on Physiognomy (first published in 1781). Others such as Dr. Gall followed with similar theories linking the physical with the moral or spiritual. These theories met in turn with a series of responses by such medical figures as George Combe, Henri de Saint-Simon and the Fowler brothers (along with many others).

${ }^{29}$ McCormick, Characterology, 242.
} 
the body and face made it easy to 'read' the supposed worth of an individual". ${ }^{30}$ The field of medicine supported this conflation of body and spirit, as signs of disease, racial difference, physical ugliness and effeminacy were widely treated as "symptoms" of an internal disorder. Both the body of the ideal man and his threatening physical countertype, in this sense, served as reminders of national order.

The end result of these emerging theories was that the human body became subject to systems of codification throughout the nineteenth century, wherein certain physical attributes were aligned with degenerative characteristics. Taxonomies of difference purported to be able to identify social others through the presence of objective and scientific facial qualities - a point which Darwinian theory developed further still as it applied concepts of racial or physical inferiority to the evolutionary development of the human race. In The Descent of Man of 1871, for example, Darwin argues that "we must bear the undoubtedly bad effects of the weak surviving and propagating their kind" - a clear reference to the need to avoid evolutionary stagnation..$^{31}$

Taxonomies of difference were equally applied to the genders and Darwin's theories of sexual selection similarly supported an association between women and degeneracy. This is especially true in Darwin's adaptation of craniological theory as he states that "the difference between the sexes as regards the cranial cavity increases

\footnotetext{
${ }^{30}$ Mosse, The Image of Man, 24.

${ }^{31}$ Darwin, The Descent of Man, 152.
} 
with the development of the race, so that the European male excels much more than the female, than the negro or the negress". ${ }^{22}$ Images of sexually-degenerate women, in particular, were bound with physical signs of their supposed immoral (and often diseased) nature. Even the image of the Amazon - signifying the threatening and sexually-powerful modern woman (who became directly linked with feminism) was, according to Barbara Larson, "considered an aberrant manifestation of savage and sexual degeneracy..., yet Amazons were often thought to represent a developmental category in evolutionary history". ${ }^{33}$

Similar theories persisted within the domestic sphere of the home in the nineteenth century, insofar as the internally-corrupt body of the unseemly mother was likewise conflated with physical, moral and social decay. The good mother, on the other hand, represented a physically-, morally-, and spiritually-evolved state. Concerns over degeneracy and evolution were therefore closely intertwined with the discussions that surrounded the "immoral mother" who would presumably give birth to corrupt offspring. Within this context, the issue of abortion (which clearly hinged on the "internal state" of the mother) also came to exemplify the degeneration anxieties that were pervasive during the fin de siècle.

\footnotetext{
${ }^{32}$ Darwin, 329-330.

${ }^{33}$ Larson, "Evolution and Degeneration in the Early Works of Odilon Redon," http://19thcartworldwide.org/.
} 
By the end of the nineteenth century, France had found itself in a state of tremendous political and social change. The defeat suffered during the FrancoPrussian war of 1870-71, which marked the end of Napoleon III's reign, fueled the proliferation of strong nationalistic sentiment in France and contributed to growing concerns over the stability of the nation. The political upheaval and devastating losses resulting from the war, coupled with what was perceived as a shift away from family values and towards decadence within French society, effectively laid the sociopolitical groundwork for a state of national uncertainty. It was widely feared that the once strong and powerful nation of France would become increasingly fragmented, while countries such as Germany continued to gain in strength and prosperity. In this context, the family - as the symbolic cornerstone of French society - became a site of growing preoccupation amid concerns over stability, depopulation rates and social decay.

In the turmoil that followed in the wake of the Franco-Prussian war, France was thrust from its position of power within Europe, as it was forced to contend with devastating casualties and economic losses. Although the post-war period was also marked by surging modernity and a blossoming bourgeois class, a latent unease emerged surrounding what were thought to be the cracks in France's social foundation - a concern which hinged largely on changes occurring within the family. While French birthrates had been relatively stable in the fifty-year period prior to the war, in the years afterward, the rates had dropped well below those of other 
countries, causing anxieties about depopulation (and its potentially degenerative repercussions) to intensify. According to statistical records, France's birthrate at the end of the eighteenth century had claimed a healthy ratio of 38 births per 1000 women. In the years spanning 1890-1900, however, the birthrate in France had fallen drastically to 22.2 births per 1000 women (while Germany simultaneously had a rate of 36.1 per 1000) and in the ensuing decade the rates in France continued to plummet further still. ${ }^{34}$

Concern over the depopulation problem in France spread swiftly, and by the end of the nineteenth century, a plethora of writings on the subject had been published and a strong pro-natalist movement had taken shape - one that was staunchly patriotic and religious, and which was concerned with identifying and removing those forces responsible for the decline of the nation. Although there was some debate (primarily in the form of Malthusian arguments) as to the defining cause of France's depopulation problem, blame ultimately came to rest on the interwoven issues of feminism and abortion, which therefore implicated women (and the French mother) as the primary threat to national stability. ${ }^{35}$

\footnotetext{
${ }^{34}$ Spengler, France Faces Depopulation, 53. The high mortality rates in France (resulting, in part, from the spread of diseases such as smallpox, typhoid, cholera, tuberculosis and syphilis) further lowered the overall rate of natural increase, which, in the period of $1890-1900$ rested at 0.7 births/ 1000 women (while Germany simultaneously boasted a rate of natural increase of 13.9/1000).

${ }^{35}$ Ibid., 222-228. Malthusian arguments of the late-nineteenth century focused on issues of class as the primary cause for depopulation (namely, that economic hardship and misuse of economic resources would drive families to have fewer children). Examples of French pro-natalist writings from the fin de siècle included Appy's Pour la France (1899); Levasseur's La population française (1889-1892); and Gonnard's La depopulation en France (1898).
} 
The state of motherhood and childbirth within the ever-shrinking French population had accordingly become a source of heated political debate by the time that Mossa painted his three images in 1905-07, as birthrate figures continued to decline while abortion figures continued to mount. Although abortions had been performed in France well before the rise of the post-war depopulation concerns (despite abortion being illegal in France since 1810, under the Napoleonic Penal Code), in the fin de siècle the issue of abortion grew in prominence as a threat to the nation. ${ }^{36}$ The topic of abortion had appeared during the mid-eighteenth century, as various writers (including Jean-Jacques Rousseau and Louis de Jaucourt) had linked it directly to the moral decline of both the family and the country. As such, in the postwar period of the late-nineteenth century, arguments in support of pro-natalist ideology expanded upon these foundational writings. By the early-twentieth century, the original law against abortion was thus amended to include much stricter punishments and penalties for those involved with abortion (although according to historical records, the procedure clearly continued to be performed). ${ }^{37}$

In 1762 the influential French philosopher, Jean-Jacques Rousseau had published Emile - a work that put forth his model for an ideal education that would yield the perfect citizen and accordingly, the ideal state. Within this text, he placed

\footnotetext{
${ }^{36}$ For more on the original law against abortion [article 317 of the Napoleon Penal Code], see Latham, Regulating Reproduction, 83-84; and Keown, Abortion, Doctors and the Law, 11.

${ }^{37}$ See Pedersen, Legislating the French Family, 164. Pedersen notes that the "Ignace Law" of 1920 included more severe punishments to both the doctors who performed abortions and the mothers who sought them.
} 
considerable emphasis on the role of the mother in creating the ideal system of education, family and statehood. In this way, he responded directly to the surfacing picture of the selfish woman who was averse to her maternal duty - one which would continue to intensify throughout the nineteenth century.

In Emile, Rousseau stressed the God-given, natural role of the mother within the moral order of the family structure, as nurturer and provider for the child, and he observed that "since mothers have despised their first duty and refused to nurse their own children, they have had to be entrusted to hired nurses" ${ }^{38}$ He focused on this pivotal moment of maternal transgression - the refusal of breastfeeding - as the point at which civic corruption is born, and his text is riddled with similar condemnations of women's rejection of the natural maternal role. He argued that only when mothers return to their proper duty of nursing and caring for their children will there be hope for a crumbling French society:

Would you restore all men to their primal duties, begin with the mothers; the results will surprise you. Every evil follows in the train of this first sin; the whole moral order is disturbed, nature is quenched in every breast, the home becomes gloomy, the spectacle of a young family no longer stirs the husband's love and the stranger's reverence. The mother whose children are out of sight wins scanty esteem; there is no home life, the ties of nature are not strengthened by those of habit; fathers, mothers, children, brothers, and sisters cease to exist... But when mothers deign to nurse their own children, then will be a reform in morals; natural feeling will revive in every heart; there will be no lack of citizens for the state; this first step by itself will restore mutual affection. ${ }^{39}$

\footnotetext{
${ }^{38}$ Rousseau, Emile, 11.

${ }^{39}$ Ibid., 13.
} 
Thus, much like the fatal transgression of the first mother, Eve, within the Garden of

Eden, which led to the fall of mankind, Rousseau emphatically attributed the original sin of the fallen French society to the mother.

For a woman to shun the duty of motherhood in favour of selfish, individualistic (and ultimately more masculine) desires, according to Rousseauian thought, was to participate in the corruption and erosion of the family, and by extension, of the country itself. He stated:

Not content with having ceased to suckle their children, women no longer wish to do it; with the natural result - motherhood becomes a burden; means are found to avoid it. They will destroy their work to begin it over again, and they thus turn to the injury of the race the charm which was given them for its increase. This practice, with other causes of depopulation, forebodes the coming fate of Europe. ${ }^{40}$

The female tendency to refuse maternal duty, then, was believed to give way to destructive female practices that obviated the "burden of motherhood". This sentiment - and this preoccupation with the mother's pivotal position within France's social fabric - was also articulated in the work of the eighteenth-century writer, Louis de Jaucourt, who expressed a similar fear that the growing urge to avoid childbirth in order to maintain a life of greater luxury had led to the invention of "a thousand means to prevent conception" and to a rising number of abortions. ${ }^{41}$

Many historians have noted the tremendous influence of Rousseau's ideas upon the political symbol of the mother that emerged in the wake of the French

\footnotetext{
${ }^{40}$ Rousseau, Emile, 12 (my italics).
}

${ }^{41}$ Jaucourt, "Fausse Couche," 598. 
Revolution of 1789 and which was again resurrected during both the French

Revolution of 1848 and the Franco-Prussian war of 1870. The female personification of France that developed over these years was a maternal, beautiful (and often sexually desirable) woman with exposed breasts, typically bearing symbolic signs of fertility, wisdom and charity. An image by Alexandre Clément (after Louis-Simon Boizot) of Republican France/Opening Her Breasts to all the French (fig.8), for example, plainly illustrates this iconographic tradition, by depicting the French Republic as a female goddess-figure who bears her breasts as if to suckle the citizens of France. Here, the allegorical image of France, which was completed three years after the Revolution of 1789 , is not only suggestive of maternal instinct, but also of a strikingly erotic beauty. Joan B. Landes has convincingly argued that such eroticized representations of the "female nation" reflected the male desire for the patriotic subject, which underscored the erotic female image with an emphasis on the maternal foundations of national strength. ${ }^{42}$ In another image dating from the time of the French Revolution of 1848, Daumier depicts The Republic (fig.9), again revealing the Republic of France as an embodiment of maternal, breastfeeding nurturer.

Rebecca Kukla, in her 2005 book Mass Hysteria, outlines the key role played by Rousseau in shaping the social position of the maternal, breast-feeding body as a morally-encoded personification of civic order and Republican ideology. She notes

\footnotetext{
${ }^{42}$ See Landes, Visualizing the Nation; and for more on the sexual implications of the Republican image of the bare-breasted female figure (including eroticized representations of Marianne), see also Aguhlon, Marianne into Battle.
} 
that the traditional image of the nurturing mother was increasingly politicized as her figure became synonymous with Republican virtue (alongside the belief that breast milk was a sort of conduit for character) - a concept that was largely fueled by Rousseau's writings. The mother's body, as Kukla suggests, "had become an essentially normatively charged medium, heavily burdened with civic hopes and responsibilities". ${ }^{43}$ The persistence of the civic connotations of both the fecund mother and her neglectful female counterpart is evidenced by the often politicized treatment of the mother and child within the work of many fin-de-siècle artists.

The political associations between the maternal body and the nation continued throughout the nineteenth century in France, as political unrest and the rising tide of feminist sentiment continued to breed unease among the more nationalist, pronatalist and religious factions of the population - an unease that saw a great deal of focus on the female body as a source of civic collapse and moral corruption. In the nineteenth century, many of Rousseau's concerns grew in strength, particularly as the women's movement gained support and greater numbers of women opted to forego their duties of motherhood in favour of greater personal liberty. Rousseau had objected to what he perceived to be a nascent women's movement in Emile, as he castigated the selfish woman with the following statement:

Women have ceased to be mothers and they do not and will not return to their duty. Could they do it if they would? The contrary custom is firmly established; each would have to overcome the opposition of her neighbours,

\footnotetext{
${ }^{43}$ Kukla, Mass Hysteria, 53.
} 
leagued together against the example which some have given up and others do not desire to follow. ${ }^{44}$

And later he continues; "Because there are a hundred or so large towns in the world where women live licentiously and have few children, will you maintain that it is their business to have few children?"45 These statements speak directly to the fashionable desire for fewer children that had grown increasingly prevalent among the upper-classes of the late-eighteenth century - a sentiment which persisted and grew in France throughout the nineteenth century.

Many late-nineteenth-century historians, in turn, seized upon Rousseau's ideas and began to develop a history of "familial decline" that centred upon the perceived displacement of the father, the shifting power of the mother, and the growth of social evils that were rooted in individualism and decadence. ${ }^{46}$ The nineteenth-century historian, Jules Michelet, for example, professed an overtly antifeminist stance, as he emphasized the inherently natural role of women as dutiful wives and mothers. ${ }^{47}$ The New Woman therefore represented a decidedly unnatural example of womanhood.

\footnotetext{
${ }^{44}$ Rousseau, Emile, 14.

${ }^{45}$ Ibid., 325.

${ }^{46}$ See, for example, Taine, Les origines de la France contemporaine (1896), 1:163-179; and Le Bon, Les lois psychologiques de l'évolution des peuples (1894), 160-164. Both Taine and Le Bon addressed the subject of the decadent French parent and the displaced father within the context of national decline. They also stressed the growing desire for personal luxury which had taken the place of concern for familial strength and the common good. A thorough discussion of the complex history surrounding the social and psychological state of the family in France during the fin de siècle is also offered by D. Hunt in Parents and Children in History, 27-37.

${ }^{47}$ Michelet, L'Amour (1858); and La Femme (1860).
} 
By 1905 - the time at which Mossa was painting - the Rousseauian image of the dutiful, breastfeeding mother as a symbol for the ordered, civilized and nurturing Free Republic had long been in circulation, and as such, the emerging body of the selfish and aborting mother of the nineteenth century stood as an unordered, uncivilized and threatening counterpart to national stability. If the breast-feeding mother with her healthy child represented the whole and stable state, then the image of the uncaring mother and her aborted fetus represented the fractured and disordered state. ${ }^{48}$

The specific concerns over abortion and the maternal body that arose in France after the Franco-Prussian war, however, were framed by not only the civic concern for the nation's population, but also by the religious and medical debates from the period. The Catholic Church was aligned with the pro-natalist, nationalist movement, as it was strongly opposed to abortion and advocated reproduction as the sole purpose of intercourse (and, in fact, saw birth control as a means of concealing sinful acts of adultery). ${ }^{49}$ Following the rise of national depopulation concerns, the Catholic Church put forth a clear, pro-natalist message on the moral imperative to produce a large family, stressing God's command to "increase and multiply" (whereas there had previously been relatively little emphasis placed on this duty within the

\footnotetext{
${ }^{48}$ Kukla, Mass Hysteria, 80-85.

${ }^{49}$ D. Hunt, Parents and Children in History, 80-88. It should also be noted that methods of birth control had been condemned by other eighteenth-century writers, such as Tissot in L'Onanisme, which was first published 1760 as one of many cautionary texts that addressed the repercussions of solitary sex (or sex that does not attempt to yield offspring).
} 
Church)..$^{50}$ In 1880, Pope Léon XIII declared that "l'homme est à la tête de la femme, comme le Christ est à la tête de l'Église" ${ }^{51}$ This position of the Catholic Church unambiguously reinforced the domestic and maternal obligations of women to both husband and God.

Moralizing religious elements underpinned many of the political debates over fertility in France: the fall of France, according to the Church, was ultimately due to a loss of faith. The good mother who helped her country by producing and nurturing the new generation of citizens was thus aligned with the ordained sacred duty of womankind - the ideal being the unattainable virtue of the Blessed Virgin Mary. Neglect of this primal and divinely-ordained duty suggested, at the woman's core, a sinful and corrupt nature.

In his 1983 book, Sexuality and Social Order, Angus McLaren provides a wideranging and in-depth examination of the debates surrounding birth control, depopulation and abortion in a largely Catholic nineteenth-century France. He notes that the decreasing birthrate at the time was attributed primarily to the burgeoning feminist movement and to its related maternal crimes of infanticide and abortion. He asserts that "Up to the middle decades of the nineteenth century, the popular image of the type of woman seeking an abortion was that of the seduced girl; from the $1880 \mathrm{~s}$

\footnotetext{
${ }^{50}$ McLaren, Sexuality and Social Order, 32-34. Here, McLaren discusses the complexities that surrounded the Catholic Church's position in relation to issues of intercourse in marriage prior to the Franco-Prussian war.

${ }^{51}$ Quoted in Bard, ed., Un siècle d'antiféminisme, 42.
} 
on, it was that of the married woman seeking to control the size of her family". ${ }^{52}$

While abortions had been long practised by midwives, it was not until the nineteenth century that the perception of the sort of woman involved in the practice shifted.

McLaren also suggests that this new perception of the abortion-seeker was tied to the belief that because smaller family sizes were so strongly desired by women, abortion was employed as an increasingly common method of family planning and birth control by the upper classes. ${ }^{53}$

The actual position of nineteenth-century feminist writings on the subject of childbirth was, however, hardly a unified one. Little was overtly stated by French feminists in defense of birth control or abortion and, in fact, many avoided the topic altogether, in order to focus on other issues of legal reform within women's rights, including marriage and divorce laws. ${ }^{54}$ And while some (such as Claire Démar) did advocate for a rejection of the traditional maternal role in order to pursue feminist goals, many others instead called for better forms of family planning (without the use of abortion) in order to provide a better quality of life for fewer children..$^{55}$

\footnotetext{
${ }^{52}$ McLaren, Sexuality and Social Order, 140. The author notes that depopulation was more likely caused by an increase in unwed women and fewer children being born within marriages, rather than by significant increases in abortion and infanticide.

${ }^{53}$ Ibid., 140-41, 147-48. Here, McLaren interestingly notes that while the recorded numbers of abortions in the nineteenth century are indeed staggering, it is difficult to judge the veracity of those claims (as figures were often inflated by opponents of the practice). Nevertheless, the recorded abortion rates in France during the fin de siècle were significantly higher than those in other countries. ${ }^{54}$ See Rendall, The Origins of Modern Feminism, 291-300. Here, the author offers a helpful examination of the goals of feminists in France (and the opposition that they encountered). She also notes that many feminists in France during the fin de siècle were in fact strongly opposed to abortion (215-230).

${ }^{55}$ Claire Démar, "Ma loi d'avenir" (first published in 1834).
} 
Opponents of the feminist movement, however, focused primarily on the issues of depopulation and familial corruption that were attributed to the female rejection of maternal, domestic duty, as well as the corresponding problems of intellectual and racial degeneration within the French population (as upper-class, intelligent French women opted to forego motherhood and thus contributed to the demise of the "better classes").56

The link between the fashionable desire for smaller families and the growing feminist movement caused great suspicion and hostility towards the female body, as the movement represented a direct threat to patriarchal institutions such as the medical profession and the church, as well as the nation itself. The association that was drawn between feminism and the increase of illegal abortions also aligned the "liberated woman" with a criminal threat to the order of law. The criminal nature of the maternal body during this period is reflected in the medical records of physicians such as Dr. Henri Rouland of the Hôpital Saint-Antoine, wherein the doctor relates tales of immoral women desiring abortions:

Many times I have interrogated women who come to ask us to finish an abortion which has begun or to cure the uterine infection caused by criminal acts. As soon as they are sure that we are bound by professional discretion, they are all quite open; some even are proud of their action and declare themselves ready to do it again, not wanting, or not wanting any more, children. ${ }^{57}$

\footnotetext{
${ }^{56}$ Lapouge and Offen, "Depopulation, Nationalism and Feminism in Fin-de-Siècle France," 650-656.

${ }^{57}$ Quoted in McLaren, Sexuality and Social Order, 148 (my italics). McLaren cites La Chronique Médicale 15 (February 1909), 120.
} 
This perception of the rather callous and reckless woman who aborts her child was common in the latter part of the nineteenth century, and underlying moral judgments were commonly entwined with not only the medical literature, but with images of fetuses that emerged within the art of the period.

In effect, the visible fetus (which was visible as a result of being removed from the sanctuary of the womb) functioned as a fundamentally moralizing symbol that carried with it overt implications of female selfishness, criminality and sinfulness. The fetus was primarily made visible for nineteenth-century audiences within the context of bottled specimens of abnormal fetuses found in curiosity exhibitions, science museums and freak shows that sought to display the "monstrous interior" of the mother's body as a public spectacle. ${ }^{58}$ Many of the moral implications that enveloped that maternal body were consequently embodied in jars of preserved fetal specimens, wherein the fetus floated in a womb-like "tomb" of glass. Exhibitions of displayed fetal monsters carried with them the reverberating fears of social decay and degeneration and as Elizabeth Grosz has argued, this process of containing, displaying and, in effect, controlling the body of the abnormal fetus represented a symbolic "colonization" of human degeneracy through the power of natural science..$^{59}$

\footnotetext{
${ }^{58}$ Menon, Evil by Design, 203-226. Menon discusses the exhibition of "monstrous fetuses" in the latenineteenth century and stresses the significance of the fetus as a sign of depopulation concerns. She also notes in brief the work of several fin-de-siècle artists (including Henry Somm, Aubrey Beardsley, Edvard Munch and Gustav Mossa) whose work reflected these concerns.

${ }^{59}$ Grosz, Volatile Bodies, ix-x.
} 
Images of the visible fetus that appeared within fin-de-siècle art thus came to straddle suggestions of both maternal guilt and degenerative deformity. By rendering the monstrous productions of the powerful and terrifying female womb more visible for a public viewing audience, the scientific displays of the nineteenth century illustrated both the shifting visibility of the mother within the public sphere and the growing movement to contain and order the degenerate body. For, as medical changes positioned the mother's body within a more visible domain, the displayed fetus also reinforced the visible nature of the womb and all of its connotations of morality and $\sin .{ }^{60}$

Preserved fetuses and medical discussions of fetal abnormalities had been central to the study of "human monsters" within the sixteenth-century and the birth of monsters had long been thought to reflect the depraved thoughts - or "maternal impressions" - of the mother. In one famous sixteenth-century example, the French royal surgeon Ambroise Paré described the birth of a child with a live snake in its back (fig.10). Here, the underlying suggestion of the mother's internal embodiment of satanic thoughts or deeds during her pregnancy was clearly evoked through the presence of the serpent born within her womb. ${ }^{61}$ The womb, in this case, contained the mark of her female sin - one that, in fact, evoked the serpent-inspired first transgression of Eve in the garden - thus illustrating the mother's ability to embody

${ }^{60}$ The moral implications of the displayed fetus reflect, again, Foucault's discussion of the significant role played by the rise of the public exhibition in shaping social ideas of normality and otherness.

${ }^{61}$ Paré, On Monsters and Marvels, 58. 
and generate evil. Physical deformity of the fetus was thus thought to be the result of the mother's illicit inner nature, which was effectively transferred to the fetus while in the womb - a notion which implicitly intersected with nineteenth-century physiognomical discussions on the external manifestations of internal sin. ${ }^{62}$

Although belief in maternal impressions within fields of medicine had lessened by the late-nineteenth century, the notion of the threatening womb was certainly not lost on this period, as the inner recesses of the female body continued to represent a site of potential danger and corruption, and diseases such as syphilis contributed to the mounting danger that was associated with the interior of the sexualized female body. Furthermore, nineteenth-century medical texts revealed a lingering concern with the allegedly inherent biological link between physical birth deformity and the "internal deformity" of the mother.

Examples of medical discussions that revealed the relationship between the womb and the moral character of the mother were also wide-ranging; most implied that the abnormal fetus ultimately represented a physical manifestation of internal female guilt. In the widely-circulated 1896 medical text of George Gould and Walter Pyle (Anomalies and Curiosities of Medicine), for example, the perverted, depraved and monstrous appetites of pregnant women are described, including accounts of women consuming dirt, excrement, the blood of their husbands, and their own milk,

\footnotetext{
${ }^{62}$ For more on maternal impressions and medical monstrosity, see Fischer, Monstres; and M. Hunt, Monstrous Imagination.
} 
as well as experiencing changes in behaviour, such as "debauchery, lasciviousness, dirty habits and perverted thoughts". ${ }^{63}$ The displayed monstrous fetus, then, as either the fearsome product of the internally-deformed mother or as an indication of her socially-transgressive act of abortion, would have been easily read and understood by fin-de-siècle audiences as an unequivocal sign of maternal guilt. Both monstrosity and abortion represented a deviation from proper codes of maternal order and signaled the onset of social decay.

The preoccupation on the part of fin-de-siècle France with guilty mothers therefore reflected the increasingly fragmented state of the family and the nation, and it is within this context that the exposed fetus came to symbolize not only the guilty mother, but the loss of stability and order within France, following a century of war and political upheaval. It is within this historical framework that Mossa's images of the mother and fetus arise. The subsequent chapter therefore examines Mossa's assimilation of these ideas, as his treatment of the fetus reveals at its core the fundamental, driving fear that permeated fin-de-siècle France - of a ruptured social order that would threaten masculinity and family, and would ultimately lead to national collapse.

\footnotetext{
${ }^{63}$ Gould and Pyle, Anomalies and Curiosities of Medicine, 80-81. The authors note that perceptions of the perverted appetites of pregnant women have a very long history in medical thought. Ambroise Paré, for example, devoted much attention to this subject, as the abnormal appetites were seen as an indication of perverted thoughts that gave way to monstrosity.
} 


\section{CHAPTER TWO}

The State of the Fetus and the State of the Nation:

Patriotic Vision in the Case of Gustav Mossa

The moral and civic meanings ascribed to the maternal and fetal body at the fin de siècle, which were the subject of chapter one, found expression within a range of artistic and literary forms that were concerned with the state of the nation and the order of the family. The body of the mother possessed particularly strong ties with nationalist sentiment within artistic traditions in France, as the maternal image (shown as an often bare-breasted, fertile and nurturing mother) had been traditionally invoked throughout the eighteenth and nineteenth century as an allegorical representation of the country of France itself - of the bountiful motherland. A significant body of imagery emerged within this period that clearly depicted the nation in the physical form of the mother. Good motherhood, as was shown in chapter one, was representative of a strong and stable nation-state, wherein the family operated according to the proper (and even divinely-ordained) hierarchies of gendered behaviour (with the mother remaining within the private domain of the home and the father aligning himself with the public duty to nationhood).

In the period following the Franco-Prussian war, the established tradition of the "ideal-mother-as-ideal-nation" was thus incorporated into the emerging politically-charged imagery that made use of the fetal motif. The fetus, however, did not mark simply a continuation of Republican ideals, but touched upon a range of 
specific social issues surrounding the family that had developed within France in the post-1871 period. The treatment of the fetus within the images produced by Gustav Mossa during the years of 1905-1907, which will comprise the focus of this chapter, demonstrates not only the lingering effects of French Republican patriotism expressed through maternal imagery, but also reveals a newly-shaped concern over nationhood, identity and society that hinged primarily on the developing issues of depopulation, feminism and social degeneration. Within this context, Mossa's fetal images illustrate the nuances found within the social conditions of fin-de-siècle France by revealing an intermingling of nationhood, gender, and morality.

By 1905, Mossa had begun to establish himself as a serious artist (following his first exhibition in 1902), working within the traditions of Art Nouveau and Symbolism and deriving influence from artists such as Gustave Moreau. ${ }^{64}$ In developing fetal imagery as a way of communicating ideas of nationhood and morality, Mossa drew considerable influence from the aforementioned tradition of the mother within Republican imagery, as well as from the work of various contemporary artists, including Max Klinger, Odilon Redon and Edvard Munch (among others) who had begun to show an interest in fetal imagery as a way of

\footnotetext{
${ }^{64}$ Soubiran, Gustav Adolf Mossa 1883-1871, 24-28. He notes that Mossa trained at the École Nationale des Arts Decoratifs of Nice from 1896-1900, where he received an early awareness of the Art Nouveau style. His artistic interest in Symbolist themes was also bolstered by a trip at the age of 17 to the Exposition Universelle in Paris of 1900, as part of an award from the École Nationale. There, he encountered a plethora of examples of Symbolist artworks at the "Exposition Centenaire de l'Art Français" and visited the many museums in Paris. Mossa's artistic studies were also bolstered by trips to Italy with his father during 1902-1903.
} 
addressing social, spiritual or psychological ideas. Mossa also drew considerable influence from the Decadent movement - a group of writers and artists (which included Joris-Karl Huysmans and Charles Baudelaire) that arose out of disenchantment with the materialism and weakness of modern French society. ${ }^{65}$ The works of other fin-de-siècle authors such as Barbey d'Aurevilly additionally offered sources of considerable influence in Mossa's treatment of immoral subjects. ${ }^{66}$ In a story titled "Beneath the Cards of a Game of Whist" in d'Aurevilly's Les Diaboliques, for example, the author describes the horrific discovery of "the corpse of a baby that had been buried alive", ${ }^{67}$ beneath the roots of mignonette growing in Madame de Strasseville's opulent flower-stand in her drawing room - a plant which she had taken to wearing on her belt and chewing. In this case, Madame de Strasseville's gruesome secret - of a murdered child hidden among the roots of her attractive flowers - points to a lurking maternal evil beneath a seemingly attractive surface. D'Aurevilly's story resonates, in many ways, with the condemnations of abortion from the period (and hence, with Mossa's maternal images), for the root of

\footnotetext{
${ }^{65}$ For more on the Decadent movement in France and its close affinities with Symbolism, see Hansen, Disaffection and Decadence.

${ }^{66}$ Soubiran, Gustav Adolf Mossa 1883-1971, 164-165. It should be noted that while Mossa's art has been consistently linked with the work of the fin-de-siècle Decadents (as he was strongly influenced by the work of J.K. Huysmans), his work does not always adhere to Decadent ideals. (The Decadents were generally opposed to traditional forms of religion, for example, while Mossa was Catholic). Nonetheless, his work often shared close affinities with the work of the Decadents, particularly in his concern with materialism and social and racial decline in France. Mossa's work tends to oscillate between a fascination with decadent subjects (which has been noted by Lafon and Clais, Gustav Adolf Mossa, 43) and a moral rejection of same. His work generally bespeaks a tension between these two positions, but it is primarily the latter sentiment which I believe is expressed in Le Foetus, Le Systeme du Docteur Forceps and La Madone.

${ }^{67}$ D’Aurevilly, Les Diaboliques, 164.
} 
evil in his narrative is ultimately marked by the body of the dead baby (whose death in turn seems literally to feed the mother's mignonette plant - a symbol for her vain interest in accessories and appearance over maternal duty).

Within art historical discourse, the movements of Symbolism and Art Nouveau have often been associated with an antifeminist reaction to the burgeoning women's movement, which responded with cautionary images of the towering Amazonian woman and the predatory femme fatale - both of whom threatened the male subject and hence, the social order. ${ }^{68}$ Examples of the feminine principle gone awry represented a negative counterpart to the existing ideal of the breastfeeding and nurturing mother of the strong nation-state, although both iconographic types served, in effect, to reinforce messages of civic order and to remind viewers of the established division between male and female, and civic and domestic spaces. While the dutiful mother maintained social order, the emerging figure of the New Woman - in the eyes of many fin-de-siècle critics - presented a direct threat to nation and family through her denial of maternal and domestic duty. As such, images of both the "good mother" and the countering figure of the "bad mother" from this period may be understood

\footnotetext{
${ }^{68}$ See Dottin-Orsini, "Portrait de femme," 119-132, in which the author uses the work of Gustave Moreau and Gustav Mossa as examples of the antifeminist artistic reaction - specifically in their images of towering, monstrous females shown alongside diminutive males.
} 
within a shared context of nationalist sentiment and opposition to shifting gender structures. ${ }^{69}$

Mossa's images of Le Système du Docteur Forceps, Le Foetus and La Madone emerge within this framework. His preoccupation with maternal themes is evident from one of his earliest images: a large-scale, unfinished oil painting of 1903 entitled L'Araignée (fig.11), which features a gargantuan and threatening Amazonian woman shown alongside both nude male figures and a miniscule Madonna and Child. Here, the mother and suckling child - the models of good citizenship and sacred motherhood - appear as fragile and threatened figures, easily destroyed by the massive figure of the Amazonian Spider, who is depicted as a fashionably-dressed, modern woman. Mossa's conflation of the timeless/sacred and the modern/fashionable within this image also sheds light on the way in which the problem of motherhood was widely perceived. In the modern woman who selfishly denied her duty to maternity was found an embodiment of the modern Eve and the female threat to humanity, while the good mother - epitomized by the Virgin Mary - represented humanity's salvation. As such, L'Araignée presents the universal danger posed to family as one that centres on the powerful modern woman.

Mossa's first evident usage of the fetal motif appears in his two 1905 works, $L e$ Système du Docteur Forceps and Le Foetus. These were completed as pendant pieces

\footnotetext{
${ }^{69}$ Several discussions on the relationship between gender and nationalism have been useful for this research, including Landes' book, Visualizing the Nation, and McClintock's essay, "Family Feuds: Gender, Nationalism and Family."
} 
in identical size and format. In Le Système du Docteur Forceps (fig.4), the scene is presented as one of depraved medical consultation, bearing overt signs (in the form of ghostly, floating fetal bodies) that the result of this consultation will involve the death of a fetus. Furthermore, the visiting doctor - presumably named for the tools of his trade (as it were) - displays rather sinister, elongated red fingers that evoke mechanical instruments designed to invade the female body.

The forceps possessed a long and complex history within the domain of childbirth, originally representing the invasion of the male doctor and his destructive instruments into the feminine space of the birthing chamber. ${ }^{70}$ Within this context, the invasive forceps were clearly aligned with the image of the masculine, destructive physician. The forceps were perceived to be highly destructive when they were first invented, as they were specifically linked with the invasive male movement into the realm of childbirth. The forceps also assumed a highly controversial position after their initial introduction into the medical community due to the botched (and rather gruesome) demonstrations of their function, and they were consequently opposed by many female practitioners who felt that such devices were damaging to women's bodies. In her examination of the history of mothers and obstetrical practices, Lianne McTavish has noted that male doctors (and male midwives in particular) were in fact associated with a range of other fearful hooks and tools (such as the ominous tire-

\footnotetext{
${ }^{70}$ McTavish, Childbirth and the Displays of Authority, 12-13. The forceps were introduced into the medical field after 1735, but it was not until the end of the eighteenth century that they were widely accepted within obstetrical practice.
} 
tête), intended to extract (and kill, if necessary) the infant in cases where the mother's life was in peril..$^{71}$ An image of 1793, taken from a text entitled Man-Midwifery Exposed (fig.12), illustrates these concerns over the invading male obstetrician, as his medical chamber is a barren room filled with ominous, piercing devices intended to penetrate the female body (while that of the female midwife, conversely, is a countering room of warmth and comfort, free of such destructive medical instruments). ${ }^{72}$

Forceps, however, as they gained acceptance within obstetric practices over the course of the nineteenth century, also came to be commonly used within the medical practice of abortion and to be therefore associated with the instrument of the death-dealing abortionist. As such, in Le Système du Docteur Forceps, the doctor's name and seemingly destructive fingers immediately place Mossa's image within a long, macabre history of medicine, wherein the male doctor was inherently aligned with the forceps and wherein he - and his destructive medical instruments participated in what was perceived as either torturous deliveries or murderous abortive procedures.

The floating fetuses that watch over the consultation at hand predict the deathly outcome of the doctor's visit (as do the tiny, fetal skulls that decorate his robe), while the fashionable appearance of the female patient and her aloof male

\footnotetext{
${ }^{71}$ McTavish, Childbirth and the Displays of Authority, 13.

${ }^{72}$ See MacDonald, Human Remains, 30-33, for a discussion of this image alongside the historical framework of anatomical study and dissection.
} 
partner simultaneously point to the upper-middle-class demographic in France that was often associated with decadent values and with privileging selfish desire for personal pleasure and wealth over duty to family and French citizenry. And, as the woman's body in Le Système du Docteur Forceps gives no indication of visible pregnancy, the "system" of the invasive doctor in this case is one of abortion. It is a system of inverted values - a corrupted social system.

The scene presents an utter reversal of the traditional depiction of the birth chamber, as here the doctor will deliver death rather than life. In this way, Mossa's image responds to the very pressing threat of abortion and its resulting rupture (or reversal, so to speak) of the French family, through depicting a moment wherein the reality of that looming social peril - the loss of life and the corruption of the family is on the verge of transpiring within the scene. Indeed, the realization of the threat at hand within Le Système du Docteur Forceps seems inevitable: the woman waits passively, her dandified male partner's glance appears indifferent, and the doctor's mouth is open, as if he is perhaps midway through accepting the task set before him. In this light, the notably ethereal and impermanent nature of the fetal bodies that double as clouds of cigar smoke within the scene also serves as a reminder of the greater state of national fragility in France resulting from abortion. And in this sense, the "corrupted system" of Doctor Forceps is one that in fact extends beyond the private domain of the family - where the illicit abortion is performed - into the public 
realm of the nation - where the ramifications of that private transgression are ultimately manifested.

The rotund Doctor Forceps, with his stereotypical Semitic physiognomic features of hooked nose and prominent pink ear (sporting a large earring), as well as his bejeweled fingers, cigar and traditional Jewish attire (of what appear to be a fedora and a white kittel robe), also presents very specific political, racial and religious meanings within Mossa's image, thus complicating the scene of "fashionable abortion". In his monograph on Mossa, Soubiran has observed the presence of antiSemitic references throughout the young artist's oeuvre, noting his use of racial stereotypes within several other works (including, for example, Israel of 1907 (fig.13), which will be discussed at greater length presently, and Les Quatre Evangelistes of 1906 (fig.14) where the four evangelists are anti-Semitically portrayed with stereotypical features, including hooked noses and prominent red ears)..$^{73}$ Imagery of this sort was common in popular cartoons and caricatures in France at the turn of the twentieth century, particularly at the time of the infamous and highly divisive Dreyfus affair which spanned roughly 1894-1906 and culminated in

\footnotetext{
${ }^{73}$ Soubiran, Gustav Adolf Mossa 1883-1971, 194. This tradition of depicting Semitic physiognomical features (hooked nose and prominent, red ears) was widespread. According to Gilman in "Proust's Nose," for example, he notes that the commonly-held, fin-de-siècle anthropological view was that male Jews had large, red ears, which often stuck out from the face. The use of the Jewish nose and ears within caricatures of the period ultimately served the purpose of signifying both physical and moral difference (64-68). See also Mosse, The Image of Man, 58-68, wherein the author discusses the social development (and sexual implications) of anti-Semitic physiognomical features (including depictions of Jews as worn and aged, swarthy men with neckless bodies and waddling gaits).
} 
the institutionalization of anti-Semitic thought in France. ${ }^{74}$ French newspapers of the fin de siècle, such as La Libre Parole and Le Petit Journal, took up the cause of anti-

Semitism, seizing upon the image of Jewishness that already existed within popularized theories of racial physiognomy. ${ }^{75}$ Mossa's anti-Semitism, which was present throughout his oeuvre, would have almost certainly been influenced by the Dreyfus affair. However, there may have been a more personal reason at the root of Mossa's resentment, stemming from his romantic feelings (from the period of 190506) for a young Jewish woman named Félice C., which were ultimately ended when the romance was broken at the insistence of Félice's parents. ${ }^{76}$

In one cartoon from a late-nineteenth-century postcard (fig.15), for example, a Jewish couple - sporting stereotypical Semitic features - parade through the streets, flashing their wealth in an arrogant fashion. The man is noticeably effeminate (especially in contrast with his massive wife) and feminization of the Jewish male was a commonly-used indicator of his symbolic inversion of the traditional Greek masculine ideal of physical beauty and strength. ${ }^{77}$ In another anti-Semitic cartoon entitled Rothschild of 1898 by Charles Léandre (fig.16), an aged Jewish man appears

\footnotetext{
${ }^{74}$ Johnson, A History of the Jews, 380-394. The Dreyfus affair involved the 1894 charge of treason against a Jewish, French officer, Captain Alfred Dreyfus. He was vindicated of the charge in 1906, after it was established that French officials created fictitious evidence to make him appear to be a German spy. The case was instrumental in revealing the pervasiveness of anti-Semitism within France. ${ }^{75}$ Ibid., 382-389. Here, Johnson notes that it was the French who first 'blurred' language and race through the popularization of pseudo-scientific race theories on Jews. On this point, he cites works such as the 1853 Essai sur l'inégalité de races humaines by Comte Joseph de Gobineau.

${ }^{76}$ Soubiran, Gustav Adolf Mossa 1883-1971, 58.

${ }^{77}$ Mosse, The Image of Man, 63-64.
} 
before a golden halo inscribed with the word "Israel". The title of the image refers to the Jewish banking family that developed a powerful financial empire in the nineteenth century, which dominated European markets. ${ }^{78}$ The inscribed "halo", then, is really an inscribed gold coin, stamped with the mark of Israel. Léandre's use of a gold coin as a debased halo points to both the wealth of the Jewish banking family and their worship of money. Interestingly, the halo framing the Jew's head recalls the halo behind the Amazonian femme fatale in Mossa's 1906 painting, Elle (fig.17). There, the Amazon's halo is inscribed with the words, HOC VOLO, SIC JUBEO, SIT PRO RATIONE VOLUNTAS (This I will, such is my command, may my will prevail over reason) - lines taken from the Roman poet, Juvenal, whose moralizing writings featured a condemning view of women. ${ }^{79}$ In both Elle and Rothschild, the "halo" is thus inverted from a sign of the sacred into a signifier of the material and profane.

In Rothschild, Léandre furthermore depicts the Jewish man with a hooked nose, large ears and gold rings as he attempts to clutch the entire world in his long, claw-like fingers (which are reminiscent, in many ways, of the long, invasive fingers wielded by Doctor Forceps). The globe that he clutches doubles as a rotund, swollen stomach, echoed by the crown upon his head that sports the corpulent body of a

\footnotetext{
${ }^{78}$ See Johnson, A History of the Jews , 314-321, for more on the Rothschild family.

${ }^{79}$ It is quite possible that Mossa may have even seen Léandre's cartoon, as such anti-Semitic imagery was widely distributed in France. These lines from Juvenal referred specifically to the misguided willfulness of a wife who foolishly resisted the command of her husband.
} 
golden calf at its apex - the latter invoking the idol of the Israelites that became a sign for the worship of material wealth. The image thus conveys the Jew's animalistic, greedy appetite for gold - and the dominance of the Jewish hold on the world's finances - as a threat to humanity. In this respect, it is worth noting that Léandre's image of the Jew with greedy, clutching claws also recalls an illustration that was published in Jacques Collin de Plancy's occultist Dictionnaire Infernal of 1863 of the elephant-demon Behemoth (fig.18) - depicted here as the monstrous demon of the gluttonous delights, shown clutching a swollen belly with claw-like hands. ${ }^{80}$ These are but two such images that cast Jews as greedy and racially inferior others who threatened the "real" French people, especially by their financial power within the nation. ${ }^{81}$ (In the first example, the wealthy Jewish couple display themselves ostentatiously, while ultimately commanding control of the city street; and, in the second, the Jewish man attempts to control not only France, but the entire world). Both images therefore bespeak a pressing fear of Jewish wealth and economic power - a sentiment that Mossa touches upon in Le Système du Docteur Forceps.

The physiognomical features of Jewish figures within popular imagery of the fin de siècle developed from the rhetoric found within wider discussions of

\footnotetext{
${ }^{80}$ The history surrounding representations of Behemoth is complex. Originally described as a large, animalistic monster within the Bible, in the nineteenth century, Behemoth evolved into a symbol of evil, a disciple of Satan, and a greedy figure associated with gluttonous feasts. For a more thorough discussion, see Van der Toorn et al, Dictionary of Deities and Demons in the Bible, 165-168. ${ }^{81}$ Johnson, A History of the Jews, 247-249. The preoccupation with Jewish wealth and greed had much to do with the financial success of Jewish populations within Europe, which spurred Christian suspicion of sinful tactics used by Jews in gaining wealth and contempt for their willingness to engage in usury.
} 
physiognomy within pseudoscientific studies of the period that sought to align degenerative physical characteristics - such as a prominent forehead and protruding jaw - with innate qualities of animality, criminality or sexual deviance. By aligning the Jew with such physiognomical qualities as the hooked nose and the red, fleshy ears, fundamental associations with disease and poor character were evoked. Large ears were generally equated with a degenerate or animalistic character, and a large, hooked nose carried even more explicit racial meaning within physiognomical theories.

In The Image of Man, George Mosse states that the "so-called Jewish nose, bent at the top, jutting hawklike from the face, existed already as a caricature in the sixteenth century". ${ }^{82}$ It was a woodcut of the Wandering Jew by Gustave Doré of 1852 (fig.19) that cemented the popularity of the stereotypical anti-Semitic image at the fin de siècle, while simultaneously linking the Jewish body with that of the immoral, social outcast. ${ }^{83}$ The Jewish nose, however, signified not only ugliness (and hence a reversal of masculine beauty) and immorality, but it also pointed to the perceived sickness and unclean state of the Jewish condition. Sander L. Gilman suggests that due to the nineteenth-century link between an ugly (and unclean) nose and the physical signs of syphilis - a sexually-transmitted disease which often resulted in deformity of

\footnotetext{
${ }^{82}$ Mosse, The Image of Man, 63.

${ }^{83}$ The moralizing tale of the wandering Jew tells of a Jew condemned to wander the earth - as an eternal vagrant - as punishment for his refusal to aid Christ. Publications such as Drumont's La France Juive (1886) also helped to pinpoint Jews as deviant enemies of Christianity.
} 
the nose - Jewish facial features also acquired an anti-Semitic association with physical, sexual and internal corruption. ${ }^{84}$ As he suggests, "the image of the Jew's nose was a 'delicate' anti-Semitic reference to the phallus. For the 'nose' became the iconic representation of the Jew's phallus throughout the nineteenth century". ${ }^{85}$ Anti-Semitic physiognomy thus conflated references to prostitution (the typical method of contracting syphilis in the nineteenth-century) with references to sexuality, disease and deformity through its physical shape.

In this way, the Jewish face allegedly bore the intrinsic mark of social, moral and familial corruption in its very appearance - a point which Mossa draws upon in Le Système du Docteur Forceps. Moreover, the presence of innate corruption is visible in not only the symbolic physiognomy of Doctor Forceps and in his phallic cigar, but in the additional symbols of death and destruction - found in the fetal skulls and the monstrous Greek Sphinx - that are woven into the cloth of his sinister robes. ${ }^{86}$

\footnotetext{
${ }^{84}$ Gilman, "Proust's Nose," 66-67; and Mosse, The Image of Man, 65. It is perhaps worth noting that these pervasive ideas surrounding "Jewishness" and sexual disease were utilized by Adolf Hitler in Mein Kampf, wherein he drew a link between social corruption (or "Jewification", as he termed it) and the spread of syphilitic infection by Jews (whom he linked with prostitution).

${ }^{85}$ Gilman, "Proust's Nose," 66 . The cigar, too, reinforced the phallic connotations latent in anti-Semitic imagery. It was a common signifier of Jewishness (and the sexual implications of Jewishness), much like the hooked nose. In fact, Jews were additionally linked with other forms of sexual transgression (including homosexuality, "chronic masturbation", and other forms of sexual transgression that suggested moral decay).

${ }^{86}$ It is perhaps worth noting that the Greek Sphinx (a mythic creature typically comprised of the head of a woman, the body of a lioness, the tail of a serpent, and the wings of an eagle) was widely used within Symbolist imagery of the femme fatale, particularly by artists such as Gustave Moreau. It is therefore fitting that the abortionist-doctor should be dressed with a symbol that conflates female destruction and monstrous aberration, given the view of abortion taken by Mossa.
} 
Mossa's references to degenerate physiognomy within Le Système du Docteur Forceps are also evident in the facial profiles of the marching male figures presumably attendants of some sort - located in the background of the image. Their cranial shapes are uniform: they all bear the visible signs of internal corruption and degeneration in their receding foreheads and protruding, muzzle-like jaws. AntiSemitic rhetoric clearly mirrored theories of racial criminality, as both the Jew and the black African were thought to represent a threat to cultural purity and national order. In both cases, the external was perceived to mirror the internal, as the misshapen body effectively mirrored the misshapen soul. The presence of these signs of physiognomical otherness within Le Système du Docteur Forceps therefore indicates many levels of social, moral, and spiritual decay caused by abortion. The use of physiognomical codes to denote character would have been easily recognized by fin-de-siècle audiences, for not only had physiognomy theories long been in circulation by 1905 , but the popular domain of cartoons and political caricature exemplified by the previous illustrations of anti-Semitic imagery (figs.15 \& 16) - also made common use of these ideas. ${ }^{87}$

\footnotetext{
${ }^{87}$ Mossa's style openly draws upon caricature, which represented a method of "allowing the artist to comment on current events and political perspectives." Landes, Visualizing the Nation, 45. Mossa's work openly incorporated an element of caricature (and physiognomical exaggeration) in order to express political ideas of nationhood. It should be noted that in Mossa's early artistic training at the École Nationale des Arts Décoratifs of Nice, he completed various studies of anatomy and botany under M. Giraudon, revealing his ability to create images of scientific accuracy and artistic illusionism. His choice to depict figures with distorted - and often "caricaturish" - features represents an informed stylistic decision on the part of the artist (Soubiran, Gustav Adolf Mossa 1883-1971, 24-25).
} 
The presence of the Jewish doctor with anti-Semitic features in Mossa's scene

of imminent abortion, then, contributes to an overall message of degeneration and criminality, as both Jewishness and abortion were widely perceived to be direct threats to the revival of France. Both were present as perceived diseases that were corrupting the body of the nation. Interestingly, Jewish doctors were also associated very closely with quackery (especially within fields such as syphilology, which were, according to Gilman, believed to be "dominated by Jews"). ${ }^{88}$ In Le Système du Docteur Forceps, Mossa casts the abortionist as the quintessential destructive Jew, and by this means, he layers references to the tradition of medical ineptitude and medical invasiveness within the historical role of the forceps with references to the racial and sexual degeneration implicit in anti-Semitic stereotypes. ${ }^{89}$ In so doing, he presents the Jewish abortionist as a dangerous symbol of invading social corrosion.

The truncated male figure in Le Système du Docteur Forceps, with whom the Jewish doctor appears to converse, sits to the left of the doctor, grasping a suggestively-phallic walking stick. Although the role of this figure within the scene of abortion is rather ambiguous, his presence (and his relationship to the other figures within the room) carries with it twofold possibilities. The notably phallic appearance

${ }^{88}$ Gilman, "Proust's Nose," 67.

${ }^{89}$ Feldman, Birth Control in Jewish Law, 268 - 291. It should be noted that Jewish doctors were not, in fact, more involved with abortions than other doctors of the period, even if this is what Mossa implies. Jewish religious texts, such as the Talmud, in fact, explicitly address the sinfulness of abortion (although the Jewish position tended to be somewhat less staunch than that of Catholic doctrine, primarily due to their differing positions on the precise moment at which the soul is infused in the body and life begins). 
of the walking stick seems to reinforce subtly the negative sexual connotations of the Jewish nose and physiognomy. Therefore, if the truncated male figure is viewed in relation to the adjacent figure of Doctor Forceps, he appears to bolster the sexual undercurrent within the image (as abortion was also commonly viewed to be the result of illicit sex, such as adultery or prostitution). Although the marital status of the couple within Le Système du Docteur Forceps is unclear, the view of abortion within the pro-natalist movement of the fin de siècle was that it ultimately arose from debased relationships (including those where the wife refused her obligation to motherhood).

The presence of the truncated male within Mossa's image also introduces a strikingly fragmented male body to the scene of abortion and social degeneration. His presence seems to underscore the threat to mankind (and masculine identity) that resulted from the shifting social order of the fin de siècle. His severed physical appearance (in lacking an upper torso and head), in this sense, illustrates the emerging male fragility that was commonly articulated within both antifeminist and antiSemitic reactions of the fin de siècle.

Masculinity was synonymous, in many ways, with an orderly social state (which was directly threatened by - or was at least perceived to be threatened by gender reversals and racial degeneration). In this sense, the fragmented male - who in turn embodied the fragility of the nation - illustrated the damaged boundaries between male and female, and public and private roles. The relationship between the 
truncated male figure and the bedridden, aborting female figure within Le Système du Docteur Forceps, then, seems to concern the destruction of these gendered boundaries and the resulting threat to masculine power (and the phallus itself, in this sense). The truncated male figure in Mossa's image embodies both the phallic symbolism frequently ascribed to Jewish men within anti-Semitic imagery and an indication of the symbolic repercussions of said transgressive Jewish sexuality: namely, a state of social degeneration and fragmented social order.

Discussion of an increasingly masculine woman and her increasingly feminized male counterpart was a prominent feature within antifeminist and pronatalist discourses of the period that reacted to the burgeoning women's movement. The notion of "feminization" was, as has already been noted, a key component of the Art Nouveau movement, which made use of a notably feminine style..$^{90}$ As such, even Mossa's use of highly decorative and feminized Art Nouveau forms within his work served to reinforce the political ideologies surrounding gender and family that feature so prominently within his oeuvre. The room depicted in Le Système du Docteur Forceps, however, complicates the sociopolitical meaning of the image while contributing to the underlying suggestions of physical and moral corruption. Although ornate and replete with feminine, curvilinear, decorative touches, the abortion chamber also reveals subtle hints at an ingrained immorality - one that

\footnotetext{
${ }^{90}$ For more on the gendered issues surrounding the development of Art Nouveau, see Silverman, Art Nouveau in Fin-de-Siècle France, 63-74, 186-206.
} 
effectively echoes the discourses on interiority within both racial physiognomy and maternal negligence.

The room includes small, decorative female portraits scattered throughout the space, as well as a folding Japoniste screen decorated with birch-tree motifs, and a violet patterned quilt upon the bed. The quilt, in turn, features a pair of images embedded within the fabric and an organic, leafy-pattern which carries over into the fabric of the doctor's robe. These decorative details within the space of the room are initially evocative of the Art Nouveau fashions of the fin de siècle, which tended to feature interiors filled with organic, feminine and botanical designs and motifs. ${ }^{91}$

These details, however, also point to the possibility of an underlying depravity within the interior. The birch tree, for example, possessed symbolic connotations of both life and death through the whiteness of its bark, which, according to Barbara Walker, "suggested its connection with the White Goddess, who was both birth-giver and death-bringer in her Crone form as the carrion-eating white sow". ${ }^{22}$ Mossa's choice of decoration within the abortion chamber was thus very apt, as the potential allusion here to the Crone Goddess (who is both birth-giver and death-bringer) evokes the stereotypical figure of the crone-like female midwife-abortionist who was

\footnotetext{
${ }^{91}$ Silverman offers an extensive discussion of both the aesthetic characteristics of Art Nouveau and its sources of influence (which included japonisme). She suggests that the modern, Art Nouveau style reflected "the retreat to an ornamental fantasy in the organized, private interior". "Nature, Nobility, and Neurology," 6.

${ }^{92}$ Walker, The Woman's Dictionary of Symbols and Sacred Objects, 461 (my italics).
} 
a common fixture in discussions on abortion and was believed to assist young, naïve girls by providing them with destructive herbs or potions.

Birch bark also served occasionally as a "charm against witches", presumably due to its association with the powers of the Crone Goddess. ${ }^{93}$ These hints at witchcraft and the evil inclinations of women within Le Système du Docteur Forceps are similarly latent in the decorative blue and white patches found on the woman's quilt. The upper patch (which is the more visible of the two) reveals five pairs of nude figures who appear coupled in embraces beneath a blue sky, containing both a white sun and six white stars. The stars appear as inverted pentagrams - a symbol that was most commonly linked with allusions to Satanism and with a sacrilegious reversal of Christian tradition. ${ }^{94}$

The grouping of nude couples beneath the star-filled sky, moreover, bears a resemblance to orgiastic gatherings akin to those attributed to witches' sabbats, which were thought to be sexual orgies of profane practices that denied generation or fertility. As Richard Payne Knight and Thomas Wright have observed, "nobody became pregnant at the Sabbath" ${ }^{95}$ In this way, then, Mossa decorates the bed of the

\footnotetext{
${ }^{93}$ Hall, Dictionary of Subjects and Symbols in Art, 11.

${ }^{94}$ Cirlot, $A$ Dictionary of Symbols, 310. The pentagram was often associated, within the Christian tradition, with the five wounds of Christ and the inverted pentagram generally pointed to black magic and the inversion of Christ's teachings.

${ }^{95}$ The witches' sabbat is discussed at length by Knight and Wright in Sexual Symbolism, 154-165; and various colourful descriptions of the celebration can also be found in Sprenger and Kramer's Malleus Maleficarum (first published in 1487). Much has been written on the witches' sabbat (as it was a popular aspect of historical investigations of witchcraft, as well as a popular fixture in literary treatments of witches). It was believed to be a profane inversion of Christian rites that worshipped
} 
decadent, aborting mother with allusions to the sinful sexual act that profaned the sanctity of the family. The signs of evil are thus woven into the very bed where she lies, as practical reminders of the sin rooted within the bed of sexual transgression.

The subtle hints within Mossa's image of witchcraft and the use of poisonous herbs to induce abortions recall in many ways the prevalent view of women as criminal, deceptive and secretive that was put forth within antifeminist discussions of abortion during the mid-to-late nineteenth century. For example, in McLaren's discussion of female attempts to prevent unwanted pregnancy, he notes that women would often attempt to induce miscarriage by "drinking an infusion of one of the traditional abortifacients such as rue, savine, or ergot of rye". ${ }^{96}$ The female consumption of destructive concoctions as a means of terminating the fetus even recalled at times the destructive and poisonous potions of witches. In M.B. Lavigne's Histoire de Blagnac of 1875, for example, he states:

At the first sign [of pregnancy] one runs to the soothsayers, the midwives, the doctors. One takes powders, brews of all sort and every kind. One delivers oneself to heavy labors, to criminal maneuvers. Sometimes one even has recourse to the * faiseuses d'anges ${ }^{97}$ *[backstreet abortionists]

\footnotetext{
Satan instead of Christ and involved sexual orgies held at night. The inclusion of both the sun and stars within Mossa's rendering of the sabbat might indicate the end of the celebration, as the orgies were said to mark the conclusion of the sabbat (which was believed to last until dawn). Or, the presence of both sun and stars might additionally allude to the fallen angel, Lucifer (who was often synonymous with Satan) and whose name meant, "Light-Bringer" or "Morning Star". For more, see Robbins, Encyclopedia of Witchcraft and Demonology, 417-418.

${ }^{96}$ McLaren, Sexuality and Social Order, 144.

${ }^{97}$ Ibid., McLaren cites M.B. Lavigne, Histoire de Blagnac (Toulouse, 1875), 373.
} 
Lavigne's references to mysterious brews and powders convey this implicit distrust of the pregnant woman that often hinged on notions of innate evil.

McLaren also draws attention to the fact that women were widely perceived to be part of a "secretive cult" of sorts, wherein female knowledge surrounding poisonous plants that were capable of terminating pregnancy was shared, typically passing from old hag-like figures to young girls. ${ }^{98}$ Hence, the women's movement of the nineteenth century was again implicated within the rise of abortion and maternal crime, as it represented the dangers of secretive female knowledge and solidarity. Moreover, the perception of the old, crone-like midwife-abortionist derived from traditions that directly linked the destructive witch with the midwife. This was generally due to the fact that midwives had secret knowledge of those abortifacient plants (including hemlock, belladonna, nightshade, and mandrake, among others), which possessed the ability to either aid or kill the child within the womb. In Michelet's history of witchcraft, which was published in 1862, he suggests that historically, midwives were often witches, adding that "what we know best of their medicine is that they used...a large family of plants - ambiguous and highly dangerous - which rendered the greatest services" ${ }^{99}$ Michelet's view derives from a long tradition of equating the midwife with the witch that dates back to the

\footnotetext{
${ }_{98}$ McLaren, Sexuality and Social Order, 144-145.

${ }^{99}$ Michelet, La Sorcière, 9.
} 
Renaissance and Middle Ages. In Henry Boguet's late-sixteenth-century text, for example, titled Examen of Witches, he explicitly aligns the two female figures:

Those midwives and wise women who are witches are in the habit of offering to Satan the little children which they deliver, and then of killing them...They do even worse; for they kill them while they are yet in their mothers' wombs. The practice is common to all witches. ${ }^{100}$

In many cases, witches were said to devour the children that they killed or offer them as satanic sacrifices.

It is therefore possible that Mossa hints, through the symbolism of the room's decor, at the innate (sexual) guilt of women through the inclusion of shrouded references to witchcraft within the abortion scene. If so, he aligns the internal guilt of the illicit woman with that of the Jewish doctor, as the two figures are symbiotically linked (as doctor and patient) within the image. Mossa's depiction of the Jewish abortionist alongside suggestions of witchcraft may furthermore point to the ways in which anti-Semitic ideas were constructed. Historian Rossell Hope Robbins has noted that historically, Jews were frequently described in very similar terms to witches; namely, as heretical and blasphemous followers of Satan. He states:

Allegations against Jews paralleled the typical accusations against witches (and other heretics), especially the use of poisonous herbs and of human bodies ritually murdered for magical potions and ointments. Conversely, witches were accused of attending a sabbat, often (especially in the earliest accounts) called a synagogue. These words representative of the Jewish religion were considered opprobrious enough to use against witches. ${ }^{101}$

\footnotetext{
${ }^{100}$ Boguet, An Examen of Witches Drawn from Various Trials, 88.

${ }^{101}$ Robbins, The Encyclopedia of Witchcraft and Demonology, 281.
} 
Robbins' statement reveals the suspicion of Jews as participants in satanic practices. His mention of "poisonous herbs" and "human bodies ritually murdered for magical potions", in particular, clarifies the possible basis for Mossa's veiled association of Judaism and witchcraft within Le Système du Docteur Forceps. In this light, the patterns of tiny skulls and plants that adorn the macabre robes of Doctor Forceps may point to the satanic, ritual uses of both poisonous herbs and murdered bodies that were ascribed to Jews and midwife-witches alike. This correlation would have been especially fitting in the case of the Jewish abortionist whose practices (which for Christians constituted murder) might have involved poisonous herbs akin to the abortifacients used by many women. The decorative quilt, then, with its ostensible image of the witches' sabbat not only alludes to licentious female sexuality and sin, but also points to the Jewish Shabbat (or Sabbath) - the term from which the witches' sabbat derives.

The domestic interior depicted in Le Système du Docteur Forceps, in this sense, is a space of internalized wickedness and degeneration that hinges on the sins of the body and that simultaneously mirrors the wider state of racial decay and crime within the French nation. This relationship is similarly central to the image of Le Foetus (fig.5) which complements Le Système du Docteur Forceps. Here, the bourgeois couple (bearing a striking resemblance to the male and female couple found in Le Système) stand amidst another Art Nouveau-inspired, highly decorative scene of wealth and opulence, and appear to prepare for an evening out. The woman powders 
her face before the mirror of a toiletry table, while her male companion (clad in evening attire) waits in the background, surrounded by decorative fish and eagles. In the central foreground of the painting, a preserved (yet still bloodied) fetus floats in a liquid-filled, ornate vessel, which resembles a golden reliquary. The displayed fetal corpse implies that this scene follows that of the abortion imminent in Le Système du Docteur Forceps and shows the consequence of that destructive act.

Viewed in sequence, the two images create a narrative of sin, akin to the tradition of prelapsarian and postlapsarian imagery of Adam and Eve in the Garden of Eden, shown before and after the fall. The fateful lapse - be it the abortion or the biting of the forbidden apple - signals both the moment of internal sin and the ensuing consequences for humanity. The narrative element of these two images also imparts a greater sense of the unfolding of social disorder within contemporary France. ${ }^{102}$

The folding screen enclosing the woman's toiletry table in Le Foetus echoes the preceding screen of birch-tree design. In the "postlapsarian scene", however, it appears to serve as a dividing wall (so to speak) between the female realm containing the disorderly mother and her macabre child - and the male realm. A lavish bouquet of flowers that closely resemble the Cypripedium orchid (known as "le

\footnotetext{
${ }^{102}$ In its narrative component, Mossa's two images recall the work of artists such as Max Klinger (particularly in his Dramen [1883], Ein Leben [1884] and Eine Liebe [1887] cycles), wherein he depicts the unfolding of social crime, prostitution, and familial destruction - often with an emphasis on the mother - over a series of episodic images showing human fallacy, temptation and sin. Klinger's depictions of crime and corruption tended to be more sympathetic than Mossa's, as he often depicts the sorrow and tragedy of poor social conditions. Varnedoe, Graphic Works of Max Klinger.
} 
sabot de la Vierge" in French) peeks out from behind the folding screen. ${ }^{103}$ These flowers, which grow abundantly in the south of France, openly signal in name the Virgin Mother - the embodiment of good motherhood. Hence, Mossa's inclusion of these flowers (which are notably removed from the enclosed space of maternal sin within Le Foetus) likely serves as a countering symbol for blossoming motherhood represented by the Virgin's namesake - which is here kept at bay. In this way, the screen that cordons off the "Virgin blossoms" renders the maternal space of the modern woman within Le Foetus a sort of reversed or disorderly hortus conclusus (namely, the enclosed, fertile garden which was associated with the Virgin Mary's sacred and pure womb). Mossa therefore casts the enclosed modern, sinful mother and her encased aborted fetus as the destructive and corrupt opposite of the Virgin Mother, her immaculate womb, and her living child.

The prominent display of the fetus within the opulence of the room depicted in Le Foetus also unites the decadent interior of the home with signs of internal decay (much like the moral implications of the room depicted in Le Systeme du Docteur Forceps), as Mossa's representation of the parental figures within this space reflects a similar condemnation of abortion and denied obligation to family and nation. The mother, despite being visually aligned with her morbid offspring, ignores the fetus and gazes vainly into her own reflection in the mirror, while the father waits in the

${ }^{103}$ The Cypripedium orchid is known in English as the "Lady Slipper" orchid. In French, it was originally called "le sabot de la Vierge" (the slipper of the Virgin), although it was also commonly called "le sabot de Venus". 
background (in a markedly passive position, again resembling that of the aloof male partner in Le Système du Docteur Forceps). Mossa thus casts the male and female figures in Le Foetus as explicitly immoral, passive and selfish - the very characteristics that were attributed to the root of familial decay in the nineteenth century.

Both figures visually merge with the interior, as the woman's dress blends with the finery that surrounds her and the man's sickly green pallor aligns him visually with an ornamental screen of green fish. In this way, Mossa seems to depict both the interior of the home and its occupants as the conflated site of corruption, since the guilty parents are ultimately fused with their lavish and decadent surroundings. Moreover, the guilty mother is "blurred" with the fetal vessel (as her body is visible through the clear glass), thus rendering the reliquary a sort of deathly glass womb. And, in this sense, Mossa's image underlines the woman's crime against maternal duty, as her womb is here rendered a cold, coffin-like vessel - a stark contrast to the glass vase that traditionally functioned as a symbol for the purity of the Virgin's womb.

The visual conflation of the male figure and the surrounding japoniste fishmotifs within Mossa's image similarly seems to underline the male figure's alignment with duty to city and society, as the fish - a frequently-used motif within Mossa's oeuvre - have been convincingly linked by Soubiran to the prominent fishingindustry that existed in Mossa's home city of Nice. The eagle motifs in the background of Le Foetus likewise represent a symbol for the city (as the image of the 
eagle with spread wings was, in fact, a crest on the official banner of arms for Nice

[fig.20]). ${ }^{104}$ As such, the male figure's alignment with the decorative background imagery within the room subtly links him with the city of Nice and with its economic, public image, thus emphasizing the gendered divisions between the male public sphere and the female domestic sphere. These references to gendered division, however, also point to the broader ramifications for city and nation as a result of corruption and dereliction that stemmed from within the home, from within the family, and even from within the mother's body.

The reliquary vessel containing the floating fetal corpse comprises the central part of Mossa's image, thus emphasizing its profound, religious significance within the scene. While the vessel closely resembles religious reliquaries in appearance - as these varied gold and bejeweled sacred vessels which were meant to contain the relics of saints featured glass compartments to display the relic - its function also suggests a monstrance. The monstrance (ostensorium) was a vessel designed for the display of the Host within liturgy of the Catholic Mass and, much like the reliquary vessel, it was made with a glass compartment to display the Host. ${ }^{105}$ While monstrance vessels

\footnotetext{
${ }^{104}$ Soubiran, Gustav Adolf Mossa 1883-1971, 136, 156. Mossa's oeuvre includes numerous references to fish and the fishing ports of Nice, as well as many examples of eagles. In addition, various paintings by Mossa reference specific locations in Nice or include examples of the city's local architecture. ${ }^{105}$ Cullmann and Leenhardt, Essays on the Lord's Supper, 56-63. The Lord's Supper (or Holy Communion) is based on the sacramental commemoration of Christ's Last Supper, wherein He said 'This is my body' and 'This is my blood', in reference to the bread and wine which was given to His disciples. The bread and wine taken during Communion are believed to undergo transubstantiation, changing into Christ's body and blood upon consumption. The sacramental rites thus recall Christ's sacrifice, in giving his life and body to atone for human sin.
} 
most commonly resemble a "sunburst" design, early medieval monstrance vessels

often featured a cylinder of glass (much like a reliquary) that housed an interior

lunette to display the Blessed Host. ${ }^{106}$ In Le Foetus, Mossa's ornate vessel refers to

these traditions of sacred display and appears to conflate elements of both the

reliquary and the monstrance, suggesting that Mossa was likely aware of the medieval

tradition of ostensoria. ${ }^{107}$

In the staunchly Catholic city of Nice, there were numerous examples of

churches housing ornate reliquaries during the fin de siècle, which may have

influenced Mossa's composition. The Chapelle de la Miséricorde in Nice, for example,

possessed a particularly rich and assorted collection of reliquaries, still visible today

(fig.21). In appearance, Mossa's fetal vessel somewhat resembles the eleventh-century

Lanterne de Bégon (fig.22), which was intended to display the relics of Saint Vincent,

or the fourteenth-century tower-shaped reliquary that housed the relics of Saint

George (fig.23), as both of these include a lavish glass display chamber. ${ }^{108}$ In form, the

${ }^{106}$ Thurston, "Ostensorium (Monstrance)," http://www.newadvent.org/cathen/11344a.htm. Here, it is noted that the general name applied to early sacred display vessels was "ostensorium". Initially, this term was applied to both reliquaries intended to display relics and monstrance vessels intended to display the Sacramental Host. Many scholars have noted the resulting difficulty in positively identifying the function of medieval ostensoria. Today, however, the monstrance and the reliquary are different in both their form and function.

${ }^{107}$ Due to the similarity in appearance between some early monstrance vessels and reliquaries, many museums simply label these as "monstrance-reliquaries".

${ }^{108}$ See Gaillard, ed., Rouergue Roman, 141-42. The Lanterne de Bégon (which is decorated with images of both Christ Enthroned and David Killing the Lion) is housed at the Abbey of Conques in Aveyron, France. It was made to display the relics of Saint Vincent. Mossa also completed what appear to be sketches of religious vessels early in his artistic training as a student, suggesting that he had visited churches and made sketches of these objects on site (fig.25). There are additionally hints at a rather personal interest in the symbolism associated with relics in a love letter written by Mossa to 
fetal vessel in $L e$ Foetus also bears a resemblance to early monstrance vessels. For example, a fifteenth-century monstrance of ornate gilded copper, currently housed at the Louvre (fig.24), features a similar outer structure and includes decorative figures of the Madonna and Child above the cylindrical glass display chamber.

Mossa's depiction of the floating fetus within the bejeweled vessel thus points to its meaning as a sacred object (while concurrently implying a profanation of the sacred through abortion). The presence of a human body within a sacred vessel recalls the Catholic tradition of displaying the bones of saints; or, in the case of the monstrance, the body of Christ Himself. The fetus's blood, although seemingly linked with the abortive process, assumes a more religious significance in this context, as the symbolic blood within the vessel evokes the Eucharistic wine-as-blood of Catholic liturgy and thus supports the possibility that Mossa here casts the fetal corpse as a stand-in for Christ's body within the monstrance. Thus, although formally closest to a reliquary, the fetus-container with its bloodied body additionally alludes to the monstrance with the wafer that is Christ's body and to the chalice of wine that is Christ's blood. In a sense, the fetal object "contains" a trinity of references: reliquary, monstrance and chalice. Mossa's representation of the fetus - as a sacred, Christly 
object - therefore renders it a sacrificial martyr for a corrupt society and a sign for the sacredness of life. ${ }^{109}$

The poppies scattered around the base of the monstrance-reliquary in Le Foetus also allude to death (a fitting symbol for the aborted fetus-martyr), and, according to scholars such as James Hall and Anne Dumas, the poppy flower also occasionally served as a lesser-known symbol for the Passion of Christ, which resulted in His death. ${ }^{110}$ This more obscure signification of the poppy seems especially apt in Le Foetus because of the conflation of fetus and Eucharist (with the bloodied fetus serving as a possible allusion to the bloody suffering of Christ). In fact, Mossa appears to have utilized this religious meaning of the poppy in his image of Christus of 1908 (fig.26), wherein Christ is shown during the Passion, carrying the cross and wearing a crown of thorns, while clothed in a robe marked with poppy-like blood stains.

The presentation of the lavish fetal relic amidst a scattering of wilted flowers is also strikingly reminiscent of the tradition of Dutch Vanitas imagery of the seventeenth century that revealed, through symbolic arrangements of opulent wealth alongside human skulls, rotting fruit and wilting flowers, a reminder of death and decay - a memento mori. In Maria van Oosterwyck's Vanitas Still Life of 1668 (fig.27), for example, a human skull is shown alongside both signs of wealth and a

${ }^{109}$ Interestingly, if Mossa indeed intended the fetal reliquary to serve as a monstrance for the Host, the fish in the background panel might point beyond the local fisheries of Nice, to the fact that in early Judeo-Christian traditions, the Lord's Supper was often depicted as a meal of fish. Fish were therefore linked with Eucharistic symbolism and were viewed as a symbol for Christ. See Cullmann and Leenhardt, Essays on the Lord's Supper, 10.

${ }^{110}$ Hall, Dictionary of Subjects and Symbols in Art, 105; Dumas, Book of Plants and Symbols, 76-77. 
lush bouquet of drooping flowers - an arrangement that is not wholly different from the displayed fetal corpse and drooping poppies in Mossa's image. Van Oosterwyck's painting exemplifies the Dutch tradition of using a symbolic still life to point to the transience of time and to warn against sin. In her painting, the book bearing the word Rekeningh ("Reckoning") and the slip of paper bearing the term SELF-STRYT("selfstruggle") serve as reminders of the mortal struggle for immortal salvation. ${ }^{111}$ The suggestive blending of Christ's sacrifice and Vanitas imagery within Le Foetus evades mutual exclusion; in fact, within the framework of Mossa's concern with the moral (and mortal) repercussions of abortion (and its links with both death and human sin), both allusions carry relevance. The aborted fetus in Mossa's work is on one hand aligned with Christ's death through its implied status as martyr and holy relic; and, on the other hand, it is cast as a reminder of death and the fleetingness of life (aptly symbolized by the dead fetus), as well as a caveat against vanity and mortal sin (appropriately hinted at by the vain mother at the mirror who committed the sinful act). In this respect, Mossa's image serves as a direct reminder of many Catholic teachings.

The fact that the monstrance-reliquary is ultimately removed from the space of the church and is instead placed amidst the immoral interior of the modern home

\footnotetext{
111 Adams, Key Monuments of the Baroque, 141-146. The tradition of the Vanitas still life (which was popular in the Baroque, Protestant art of Flanders and the Netherlands in the seventeenth century) often made use of flowers that were beautiful, yet were just on the cusp of wilting. These highly symbolic works were intended as moralizing reminders of the fleeting nature of human life and mortal beauty.
} 
may reflect Mossa's interest in capturing the "reversal" of values at play within the decadent society of the fin de siècle, wherein the aborted fetus ultimately serves as relic. His representation of the fetus as a bloodied and martyred Christ-figure extends his condemnation of the neglectful parents further still: for their crime is one that not only disrupts and reverses the order of family and society, but subverts spiritual order as well.

The indication of an inverted Christian order presented by the monstrancereliquary in Le Foetus is more plainly evident in Mossa's 1907 oil painting, titled Israel (fig.13). Here, he returns to the theme of Jewish perversion, as the Jewish male figure is shown before a display of golden reliquaries and statues. He serves as the priest, holding in his hands what appears to be an ornate sacramental cup of the Holy Mass and a golden coin (in place of the Wafer). Beside him, Mossa depicts a young, red-haired girl who reaches her hand into the jaws of a monstrous or demonic golden statue and appears to feed the Host to this grotesque reliquary. The scene in Israel thus mimics the Catholic Mass and the sacred taking of Holy Communion, but actually points to the inverted satanic rites performed for the Black Mass - a common fixture in discussions of witchcraft - which were said to involve various sacrilegious parodies of Christian rituals. ${ }^{112}$ The young girl's presence within this scene also hints

\footnotetext{
112 The Black Mass was often said to involve a young girl, as the liturgical rites of desecrating the Host would be performed on her naked body. Robbins has observed that "every witches' sabbat was supposed to include a diabolical service, but the 'black mass' as such is not found in any contemporary account of witchcraft, and the term became current only at the end of the nineteenth century." The
} 
at the possibly lecherous nature of the "rites" that will be performed by the Jewish priest. ${ }^{113}$ However, while Israel depicts an overt defilement of the Host and an inversion of the sacred, in Le Foetus, Mossa's treatment of the fetal body implies an oscillation between defilement and purity.

The appearance of the monstrance-reliquary within Le Foetus supports a religious (rather than sacrilegious) reading of the fetus, as the holy vessel has a diminutive figure of the Apocalyptic Woman (identifiable through her crown of stars) on its apex, resembling the placement of the Madonna and Child as ornaments on the fifteenth-century gilded copper monstrance (noted in fig. 24). The Woman of the Apocalypse is described in the Book of Revelation as follows:

And a great sign appeared in heaven: A woman clothed with the sun, and the moon under her feet, and on her head a crown of twelve stars. And being with child, she cried travailing in birth: and was in pain to be delivered. ${ }^{114}$

Within Catholic doctrine, the Woman of the Apocalypse and the Virgin Mary are two distinct figures. In fact, the cries of pain emitted by the Apocalyptic Woman

\footnotetext{
Encyclopedia of Witchcraft and Demonology, 50. Robbins further notes that although the Black Mass was, in effect, a literary creation, arising mainly from vivid literary descriptions of the blasphemous event (which were founded on the provocative accounts told by accused women while under torture during sixteenth-century witch trials), prominent nineteenth-century historians such as Michelet (in Sorcière) nonetheless accepted the Black Mass as historical truth (50-51). Whether or not Mossa similarly accepts it as truth is unclear, but certainly, he uses the Black Mass as a way of conveying the seriousness of the Jewish threat to Christianity (while also demonstrating his awareness of the pervasive linking of Jews with witches within Catholic tradition).

${ }^{113}$ Here, Mossa may have been influenced by Huysmans' infamous satanic novel La-Bas (or Down There), which included many detailed accounts of the perversions involved in satanic ritual. Many of these involved sexual acts performed during the Black Mass. Huysmans' novel also described a nineteenth-century case where French women would take communion and save it in their mouths in order to defile it afterwards (64-65).

${ }^{114} \operatorname{Rev} 12: 1-2$.
} 
during childbirth render her more like Eve than Mary. Nonetheless, her image became intertwined with that of the Holy Mother within iconography surrounding the Assumption and the Immaculate Conception, as Mary was often depicted with a crown of stars and a silver crescent moon during these moments. ${ }^{115}$ The monstrancereliquary containing the fetus, then, acts as a reminder of the primal and divine nature of the maternal duty to bear children. This reminder of Holy Motherhood atop the sacred-yet-profaned fetal reliquary contrasts sharply with the fallen French mother in the background. On the whole, the significant disparity in scale between the ornamental figure of the Apocalyptic Woman and the looming (yet indifferent) French mother recalls Mossa's representation of the Amazonian modern woman alongside the diminutive (and thus threatened) Madonna and Child in L'Araignée (fig.11).

Moreover, like the Virgin Mother whose womb was equated with a pure, glass vase, here the transparent glass of the monstrance-reliquary also seems to invoke an allusion to the Marian womb - the perfect maternal vessel that contained Christ. ${ }^{116}$ In Le Foetus, however, the idyllic womb of the Immaculate Conception is ultimately reversed, with the glass revealing an interior of death within the disorderly womb of the sinful and decadent mother.

\footnotetext{
${ }^{115}$ Katz, "Regarding Mary," 95.

${ }^{116}$ In traditional imagery of the Virgin Mary, she is often depicted alongside a glass vase filled with white lilies, as both the flower and vase serve as symbols for her physical and spiritual purity.
} 
The image of the liquid-bound fetus encased in glass, however, also points to a more profane meaning, as it distinctly recalls the traditions of fetal displays that were found within monstrosity exhibitions and carnival freak shows, as well as museum exhibitions of the fin de siècle (see fig.28). As discussed in chapter one, these popular displays of human aberrations were entwined within a matrix of social fears surrounding degeneration, abortion, feminism, and the womb's power to corrupt through maternal impressions. ${ }^{117}$ In fact, the distended head-shape of the fetus (which was also visible in the fetal ghosts of Le Système du Docteur Forceps) recalls the fetal disfigurements commonly found in many monstrosity displays, particularly in cases of hydrocephalic fetuses with enlarged craniums. ${ }^{118}$ If Mossa's image indeed draws from the tradition of the displayed fetal monster, then its cranial deformity may even reflect the physical embodiment of its mother's immoral thoughts and deeds. The image of Le Foetus thus shifts between the sacred and the profane, with allusions to the perfect, vase-like womb of Mary, the reliquary and monstrance, and the vessel of monstrosity and innate maternal guilt.

\footnotetext{
${ }^{117}$ Mossa was likely able to view monstrosity displays when he traveled to the Exposition Universelle of Paris in 1900, which included a human zoo, along with other displays of human otherness. In addition, the Musée Dupuytren in Paris housed numerous examples of medical abnormality and featured many examples of malformed fetuses kept in jars of alcohol. The Muséum d'Histoire Naturelle in Paris, as well, contained many displays devoted to subjects of evolution and human anatomy. It is therefore almost certain that Mossa would have encountered these displays while studying art and visiting the museums in Paris.

${ }^{118}$ While the consistently enlarged head-shape of Mossa's fetal figures suggests deformity, it is also possible that Mossa's imagery developed from having seen fetal displays that featured earlier stages of fetal development (of around 2-3 months gestation) when the head is more developed than the rest of the body.
} 
In another 1905 work titled La Marchande d'Amour(fig.29), Mossa makes

explicit use of the bottled fetus motif as a way of depicting social disorder, although in this case he refers overtly to the sexual corruption of the prostitute. He depicts a bare-breasted "Cupid seller" - a reference to the sale of sexual love - offering infantile Cupids with butterfly wings (presumably for illicit use) to a crowd of male clients, (including a string of decadent male officials, politicians and aristocrats - and many with stereotypical Semitic features - who congregate in a disorderly mass within the city street). La Marchande d'Amour likely drew considerable inspiration from Joseph Vien's French Neoclassical work, The Cupid Seller, of 1763 (fig.30), which had used the male Cupid to symbolize the sale of an object of female sexual gratification. ${ }^{119}$ In Mossa's image, however, the scene is not one of charmingly coy erotic intimation, as the unprecedently female Cupids appear to shriek and struggle, while hanging from hooks like carcasses of meat in a butcher's shop. In the far lower left of the image, Mossa depicts a fetal Cupid submerged in a glass jar.

The underlying meaning of La Marchande d'Amour therefore points to the condemnable end result of sexual depravity, adultery and prostitution: the aborted fetus. The struggling female Cupids evoke the grisly realities of young prostitutes whose bodies are sold for male sexual pleasure. ${ }^{120}$ The "sacrifice" of the child-like

\footnotetext{
${ }^{119}$ See Chu, Nineteenth-Century European Art, 49-50. Vien's painting drew from an engraving that was based on a recently excavated wall painting from Herculaneum.

${ }^{120}$ Soubiran touches on this aspect of the image (although he neglects to note the presence of the fetus), as he suggests that La Marchande d'Amour in fact reflects a somewhat more pitying approach to the
} 
Cupids in Mossa's painting recalls the Biblical Massacre of the Innocents from the Gospel of Matthew - an event which was commonly invoked in anti-abortion messages and which Mossa in fact treated in a small image from 1917 titled Massacre of the Innocents (fig.31), as part of a series on the life of Christ.

On yet another level, however, Mossa also refers subversively to a lateeighteenth-century iconographic tradition wherein the image of Cupid (or Eros) was aligned with the figure of the bare-breasted Republican mother of patriotic virtue. In Love of the Fatherland (fig.32) of 1793, for example, France is represented as an eroticized and bare-breasted mother-figure, paired with a young, child-like Cupid. This depiction of maternal France with Cupid was a reminder of the "physical consequences" of patriotic love for the nation/mother - namely, the offspring produced through the performance of marital duties. ${ }^{121}$ Thus, while the bare-breasted France represented the desire for the nation, the inclusion of the Cupid emphasized the idea of procreation within a patriotic context. As in the previous images of $L e$ Système du Docteur Forceps and Le Foetus, Mossa both alludes to and inverts this patriotic message in La Marchande d'Amour. For, unlike the virtuous and erotic, bare-breasted embodiment of maternal France, Mossa's Cupid Seller embodies sexual corruption. Her "Cupid wares", then, rather than asserting the motherly role of prostitute's world - at least as far as the child-like Cupids are concerned (Gustav Adolf Mossa 18831971, 204).

${ }^{121}$ Landes, Visualizing the Nation, 155. 
France, reflect instead the destruction of the home and nation as the result of illicit sex and abortion.

A strikingly different depiction of the mother and fetus can be found in the 1907 watercolour painting by Mossa, titled La Madone (fig.6), which pairs the fetus with the figure of the Virgin Mary rather than with the corrupt mother. In many ways, Mossa's image of benevolent motherhood stands as a counterbalance for and antidote to both Le Système du Docteur Forceps and Le Foetus, for unlike the deathly figures found in his previous images, in La Madone the fetus appears alive and growing within the womb of the ideal mother: the Virgin Mary.

The maternal and overtly pregnant Virgin Mother - who appears here with a parted robe, decorated with feather motifs that cause her to resemble a winged angel - stands with her hands crossed at her heart, as a symbol for her acceptance of maternal duty to God. She resembles a modest, contented, and protective mother who shelters the fetal Christ-child that grows within her womb. Christ gazes upward towards his mother, while she appears to return His gaze through her downcast (and introspective) glance. Mossa depicts the Christ-as-fetus within the Immaculate womb (here represented by a framed roundel bearing the twice-repeated word, ALLELUIA). His placement of the word ALLELUIA within the Virgin's transparent womb thus quotes the Christian liturgical expression of triumphal joy (meaning "Praise God") from the traditional hymn of the Catholic Sunday Mass, which, in La Madone, effectively suggests joy that the Word has literally been made flesh. Mary's womb also 
reveals a placenta-like form that surrounds the Christly fetus. Its appearance creates a golden cross-shape behind Christ, thus reaffirming the divine purity of her womb and the central position of Christ within the Christian faith.

The maternal, protective and nurturing Virgin thus restores the disorderly image of the neglectful, decadent mother by reverting to Catholic tradition. The Virgin Mary in Mossa's image embodies the purifying role of the New Eve who was sent to repair the sins of the first Eve in the Garden of Eden. In this sense, Mossa seems to invoke the quintessential Good Mother as a purifying counterbalance for the aborting New Woman of the fin de siècle. In La Madone, the Virgin's body presents a clear reversal of the corrupt glass womb/reliquary within Le Foetus, as Mossa here renders the idyllic maternal womb as a sort of divine portal, making visible the living, joyful and sacred interior of the Virgin's womb. Similarly, the reciprocal gazes of the fetus and mother in La Madone (seemingly transmitted through the boundary of the physical body) offer a marked contrast to the cold, self-interested and indifferent gazing of the mother-figure in Le Foetus.

Mossa's reverent treatment of the Madonna and her fetus therefore supports the religious and pro-natalist image of ideal motherhood. In addition, his depiction of the fetal Christ within Mary's transparent womb recalls a long tradition (going back to the eleventh and twelfth centuries) of devotional imagery wherein the Virgin's womb was rendered like a transparent rose window or monstrance. In one image dating from c. 1400 and titled Maria Platytera (fig.33), for example, a pregnant Mary is 
shown with Christ in utero - with her womb represented by a golden roundel. ${ }^{122} \mathrm{La}$ Madone thus emphasizes the divine nature of maternal obligation by drawing upon a well-established tradition of maternal Marian imagery. It was also common to see Mary's figure incorporated into the monstrance itself. In a monstrance from the Church of the Immaculate Conception in Northern France, for example, the figure of the Virgin is directly aligned with the glass chamber of the monstrance, as if she reveals the Eucharist through her body (fig.34). ${ }^{123}$

The appearance of the "revealed portal" of Mary in Mossa's image, however, most closely resembles the circular form of the Gothic rose window that was traditionally divided into segments by tracery that radiated outward from the centre of the window. By invoking the architectural form of the rose window within the very body of the Virgin, Mossa's image of the Virgin's womb simultaneously points to the traditional relationship between Mary's body and the Church itself within religious doctrine. ${ }^{124}$ In fact, the rose window that appeared within Gothic churches frequently included ornate stained glass imagery with Mary or Christ located at the very centre. In Chartres Cathedral, for example, the northern and southern transepts feature rose windows with central images of the Glorification of the Virgin and Christ

\footnotetext{
${ }^{122}$ Belan, The Virgin in Art from Medieval to Modern, 45. The name "Platytera" refers to traditional Marian imagery, where Mary's body unites the roof of the Church with the floor, symbolically uniting the heavens and the earth. In this tradition, Mary is frequently shown with the unborn Christ within her golden womb.

${ }^{123}$ Vloberg, L'Eucharistie dans l'art, 289-290.

${ }^{124}$ The rose window was also commonly linked with the Virgin Mary in name, as she was known as the "Mystical Rose".
} 
Blessing (fig.35). Mossa's depiction of the fetal Christ explicitly refers to this architectural tradition, and the connection between Mary's body and the physical Church within La Madone is asserted further by the prominent presence of the church in the background of Mossa's image.

Soubiran has convincingly linked the image of the pregnant Madonna with the local Chapelle de Saint Suaire de Turin in Nice (fig.36). ${ }^{125}$ Although the appearance of the church of Saint Suaire in Nice differs considerably from that of the church depicted in La Madone, the Chapelle de Saint Suaire contains within it a lateeighteenth-century sculpture of the Mater Expectationis (or the Expectant Madonna) (fig.37), which was a common focus of prayer for couples hoping to conceive children. This sculpture shows a pregnant, golden-robed Madonna within a niche, decorated with stars. ${ }^{126}$ Ornamental motifs, including two small cherubs and garlands of flowers, surround the niche. Beneath the Virgin's robes in Mossa's painting, two strikingly similar, cherubic figures grasp musical instruments, which, in all likelihood, refer to the musical hymn of Alleluia.

In this sense, then, the allusion to a local church within La Madone also provides Mossa's image with a fitting physicall setting within Nice for the musical

\footnotetext{
125 Soubiran, Gustav Adolf Mossa 1883-197, 135. The Church of Saint Suaire was founded to mark the fact that the Shroud of Christ was said to have traveled through Nice on its way to Turin, stopping at the Chateau de Nice along the way. The church was built to commemorate the presence of this Christly relic within Nice. (Details were kindly provided by the Priors at the Chapelle de Saint Suaire in Nice).

${ }^{126}$ The presence of stars above the head of the Expectant Madonna at the Chapelle de Saint Suaire reflects the tradition of 'blending' the attributes of the Apocalyptic Woman with the Virgin of the Immaculate Conception.
} 
refrain of Alleluia that surrounds the Christ-in-utero. What's more, his allusion to a church devoted to the shroud of Christ provides an indirect reference to both the tradition of the sacred relic and Christ's death, thus tying the image of La Madone to his previous depiction of the fetal relic in Le Foetus. This connection between the two paintings is further bolstered by Mossa's illustration of the revealed fetal Christ within Mary's womb (surrounded by the music of the Catholic Mass). In effect, the rendering of Mary's womb as a transparent rose window in La Madone signals that the visible, living fetal Christ within Mary's "sacred vessel" here too embodies the Holy monstrance (thus offering a corrective complement for the aborted fetal Christ within the monstrance-reliquary in Le Foetus). And, as in the monstrance-reliquary elision in Le Foetus, here we have conflation of rose window and monstrance. Arguably neither is redundant nor confused, but rather richly and deliberately multivalent.

By placing the Virginal Mother within the local setting of Nice through an allusion to the Chapelle de Saint Suaire, Mossa consequently places her squarely within France. As such, she functions as an emblem of not only motherhood and the Church, but of the French nation. The eagles (once again, as iconic symbols of Nice) that perch upon the Virgin's shoulder strengthen this dimension of the image, as does 
the unusual "winged cloak" worn by Mary, which folds protectively around the fetus. ${ }^{127}$

This image of the Virgin-as-fetal-protector refers directly to the traditional image of the Madonna of the Misericordia (or the "Mother of Mercy"), who shields humanity from divine wrath with her mantle. Mossa's allusion to the Madonna of the Misericordia in La Madone reflects his awareness of the Chapelle de la Miséricorde in Nice (fig.39) - a Catholic church devoted to the Madonna of Mercy, situated only yards away from the Chapelle de Saint Suaire. The walls of the church are adorned with numerous rose windows (fig.40), and inside the sacristy is an altarpiece painting by Jean Miralhet of La Vierge de Miséricorde of c.1429 (fig.41), depicting the Merciful Madonna spreading her mantle over the heads of the faithful. ${ }^{128}$

In a c.1394 painting by Jacobello Alberegno from the Galleria dell'Accademia in Florence (fig.42), the Madonna of the Misericordia is shown with an infant Christ in a rounded "portal" of sorts upon her chest (akin to the "window-womb" of the

\footnotetext{
${ }^{127}$ Mossa in fact made use of this motif of the protective, winged Madonna figure within his own home. In a photograph taken after the birth of his daughter (whose name was, in fact, France), Mossa can be seen with his wife and child beneath the protective wings of a decorative seraph-Madonna figure, painted upon the very wall of his home (fig.38).

${ }^{128}$ Mossa's own awareness of this painting is confirmed by his reference to it within an essay that he published (albeit decades later) as part of the Centenaire du rattachement de Nice (1960) - a collection of articles on the history of Nice. Mossa, who was then working as the curator for the Musée des Beaux Arts in Nice published, two essays on the art of Nice in this collection, and in his essay entitled "Les Arts" he includes a black and white reproduction of La Vierge de la Miséricorde.
} 
Virgin in La Madone), as she spreads her mantle over the heads of her worshippers. ${ }^{129}$ At the upper left and right corners of Alberegno's painting, scenes of the Annunciation appear. Another image, Francesco Granacci's early-sixteenth-century painting of Our Lady of Mercy (fig.43), which was made for the Foundling Hospital of the Holy Innocents in Florence, shows the Madonna of the Misericordia spreading her protective mantle over a group of huddled children and swaddled infants. A golden cross that is analogous to the golden cross-shape found within the womb of Mossa's Madone, is emblazoned over the area of her abdomen - a reference to the Immaculate Conception and the holiness of her womb. This iconographic convention of the Madonna of the Misericordia grew in popularity in the years after the devastating Black Death of 1348 (as she was frequently invoked as a protector against the plague) and images of swaddled infants were widely used in plague imagery because swaddled infants had often survived the bubonic plague (in large part due to the tight swaddling that helped to stave off tick bites and other sources of infection). ${ }^{130}$ Granacci's image thus emphasizes the Madonna's role as a physical protector of vulnerable children.

In this iconographic tradition of the protective Madonna of the Misericordia, Mary was a virtuous corporeal "shield" of sorts. Because the stance, demeanour and

\footnotetext{
${ }^{129}$ Belan, The Virgin in Art from Medieval to Modern, 44-45.

${ }^{130}$ Verdon, Mary in Western Art, 191-193. For more on the image of the Madonna of the Misericordia within the history of the Black Death, see Meiss, Painting in Florence and Siena After the Black Death, 74-75; and, for more on both plague imagery of swaddled infants and the Virgin Mary, see Boeckl, Images of Plague and Pestilence, 48-52.
} 
appearance of the Virgin in La Madone is virtually identical to that of the medieval Misericordia tradition, it seems likely that Mossa's rendering of the Virgin was ultimately meant to emphasize her role as a maternal and merciful protector for the vulnerable fetus - one who was threatened, in effect, by the modern, moral "plagues" of the fin de siècle, namely, the women's movement, racial corruption and abortion.

The fetal motif that appears in Mossa's oeuvre was thus one that was defined by ambiguity and flux, whether as the spectral ghost within the degenerative abortion scene, as the macabre yet sacred martyred object within the monstrance-reliquary, or as the divine result of the Immaculate Conception, made visible in a kind of monstrance-womb. For Mossa, the image of the pregnant mother (and her countering image of the aborting mother) carried great significance within a national and religious context. By the end of the nineteenth century, the image of both the mother and the fetus pointed to specific social anxieties of the fin de siècle which ultimately rested on the tenuous state of France and the social ills that were responsible for the country's decline. In Mossa's work these anxieties (ranging from anti-Semitism, degeneration and sexual corruption, to the women's movement and depopulation) were fully crystallized. In this way, the ambiguity and flux that characterized Mossa's representation of the fetus pointed directly to the underlying social instability that framed the fetus of circa 1905-07. 


\section{CHAPTER THREE}

Transgressing Boundaries:

The Fetus and the Revealed Interior

The idea of society is a powerful image. It is potent in its own right to control or to stir men to action. This image has form; it has external boundaries, margins, internal structure. Its outlines contain power to reward conformity and repulse attack. There is energy in its margins and unstructured areas. - Mary Douglas ${ }^{131}$

The image of the fetus that appears within the work of Gustav Mossa was firmly situated within the rise of concerns over decay and degeneration in France. His images were also rooted in more general concepts of order and disorder, as the fetus represented an originating site of rupture within the maternal body with far-reaching effects within the social fabric of France. In separating order from disorder, historians and theorists alike commonly speak of boundaries (which may be conceptual, spiritual or physical in nature) that effectively shape, separate and classify the orderly and the disorderly. In chapter two, Mossa's portrayal of the fetal motif was linked with both the sacred and the profane. In this respect, the fetus symbol represented a liminal space in between these two poles of order and disorder. This chapter will seek to examine the way in which Mossa's fetal imagery signaled boundaries of order and the transgression of those boundaries, first by considering the changing way in which the concept of the interior was constructed during the fin de siècle, and

${ }^{131}$ Douglas, Purity and Danger, 141 
secondly by considering his use of the fetus in relation to broader theories of transgression and the sacred. As a symbol, the body of the fetus existed at the very borders of social rupture and fragmentation. It rested on the figurative dividing boundary between not only order and disorder, but also the masculine and the feminine, the interior and the exterior, the sacred and the profane, and life and death. Mossa's highly nuanced treatment of the fetus sheds light on these issues and, moreover, points to the ambiguities that complicated those borders of existence at a time when they were of key concern to the French population.

In all of Mossa's fetal images, he presents a visual "blurring" of borders through the presentation of the fetus within liminal, interiorizing spaces. In Le Système du Docteur Forceps, for example, the mass of fetal bodies float overhead as both transparent plumes of smoke and as ghostly indicators of an imminent abortion. Their presence is emphatically ethereal and impermanent - and even invisible - as the other figures within the scene appear oblivious of their existence. In Le Foetus, Mossa presents the fetus as a floating deathly figure, although here its corpse hovers within a liquid-filled vessel that doubles as both reliquary and womb-like coffin. As such, it points to life and death, and sin and salvation through its intermediary state. Finally, in La Madone, the fetus is again depicted as a floating body - although here, it is distinctly alive and floating within the protective space of the Virgin's transparent womb. Here too, Mossa creates a sense of flow between boundaries, as he renders the Virgin's womb a visible window-like portal (or monstrance) that makes visible the 
Christly, maternal interior. In every case, the fetal body exists in a space of liminality between two realms and that oscillates between inside and outside, presence and absence, and before and after.

The preoccupation with interiors - and the boundaries that separate them from their external surroundings - was a defining quality of the Art Nouveau style. As was noted in the introductory chapter of this thesis, the creation of an interiorizing, feminized art form was closely linked with the perceived rupture of gendered order that resulted from the women's movement. The modern concerns over the order of the family and the body of the mother all hinged on a growing interest in interiority. In many ways, the fin-de-siècle interest in "capturing" the female, maternal and domestic interior mirrored the widespread nineteenth-century drive to investigate the relationship between the internal and the external, which spanned diverse avenues of thought.

The concern with interiority could be seen, for example, in the scientific and medical projects that sought to uncover the internal world of invisible microbes and germs, made possible through the developing technologies of the microscope, the photographic camera and the X-ray. Minute signs of degeneracy were traced upon the body through the studies of physiognomy and phrenology, which similarly hinged on a concern with the physical signs of the body's moral interior. Emerging studies of psychology, too, concerned themselves with the discovery of the internal structure of the unconscious human mind; and even the budding interest in spiritualism and the 
occult during the nineteenth century reflected a desire to see and understand the unseen realities that lay beyond the threshold of death. ${ }^{132}$ In some cases, this newlyrevealed "internal world" was understood as a microcosmic symbol for the macrocosm of national disease and decay.

Writing on the subject of the invisible realm of spirits in his novel Down There of 1891, the Decadent writer Joris-Karl Huysmans wrote:

Space is peopled by microbes. Is it more surprising that space should also be crammed with spirits and larvae? Water and vinegar are alive with animalcules. The microscope shows them to us. Now why should not the air, inaccessible to the sight and the instruments of man, swarm, like the other elements, with beings more or less corporeal, with embryos more or less mature? ${ }^{133}$

Huysmans' description of invisible spirits and swarms of microbes invading the modern age articulates the fin-de-siècle perception of the modern impulse to discover what lay within the interior of existence, beyond the boundaries of the visible.

The Symbolist artist, Odilon Redon, captured this invisible world of ambiguous cells, microbes and embryonic forms in images that predated the statements made by Huysmans. ${ }^{134}$ In a charcoal drawing of 1880 entitled In the Primeval Slime (fig.44), for example, Redon illustrates floating embryonic, cell-like forms that double as human heads. These forms conflate references to evolution (and

\footnotetext{
132 See Stafford's Body Criticism for a through discussion of the scientific exploration of the 'invisible' realms of the human body throughout the late-eighteenth and early-nineteenth century.

133 Huysmans, Down There, 131.

${ }^{134}$ Huysmans wrote about Redon's work and commented on his early exhibitions in L'Art Moderne, 274-277.
} 
degeneration) with hints at microbial germs. The title of Redon's image evokes the dank, dark origins of human disease, while his representation of floating, luminous cells and/or heads that appear to emerge from the primordial muck oscillates between a sense of spiritual growth and the pollution of the body. Redon's work generally tended to embrace a confusion of forms, which rendered them at once transcendent and pathological. ${ }^{135}$ This ambiguity of meaning is ultimately shared by Mossa in his treatment of the fetus.

Mossa's awareness of the unseen world of floating forms described in Huysmans' novel is especially evident in his image of Le Système du Docteur Forceps. Here, the floating cloud of fetal bodies hovering between flesh and spirit clearly evokes Huysmans' suggestion of "beings more or less corporeal" and air filled with a swarm of "embryos more or less mature". In this sense, Mossa's image of fetal ghosts makes visible the underlying unseen realities that existed beyond the veneer of the bourgeois interior.

In her wide-ranging discussion of the Art Nouveau movement, Debora Silverman has suggested that the decorative and feminizing designs of Art Nouveau artists were closely linked with not only the desire to recapture a gendered order through the domestic interior, but also with the growing general awareness of "internal states" within other avenues of fin-de-siècle thought. She argues that the Art Nouveau style was strongly affected by the concepts of unconscious projection and

${ }^{135}$ Larson, The Dark Side of Nature, 87-88. 
inner vision that were central to developing theories of the human psyche being put forth by Jean-Martin Charcot and his student, Sigmund Freud, as well as Hippolyte Bernheim, among others. ${ }^{136}$

Charcot, through his influential studies of hysteria undertaken during the late nineteenth century, looked closely at the relationship between the disorderly external body and its accompanying internal disturbances. His studies related primarily to the female body whose "unruliness" was generally believed to originate within the womb and then manifest itself outwardly. ${ }^{137}$ Bernheim, who was a contemporary of Charcot, wrote on the subjective boundaries of the individual, stating that it was necessary to dissolve "the stable boundaries between inner and outer, subjective and objective reality", ${ }^{138}$ so that there would be a reciprocal flow between the human psyche and the external world. These ideas, which centred on a blurring of the interiority and exteriority of mind and body affected, in turn, conceptions of interior décor and artistic creation.

Mossa's awareness of the new psychological theories of the period is virtually certain, as his oeuvre includes titles that refer explicitly to psychological concepts of

\footnotetext{
${ }^{136}$ Silverman, Art Nouveau in Fin-de-Siècle France, 75-106.

${ }^{137}$ Kemp, "A Perfect and Faithful Record,"139-142. There were also recorded cases of male hysteria, but Charcot mainly documented the female hysteric. His work was pivotal in defining the disease as one of weakness, nerves and unruly sexuality. Charcot also employed photographic methods of documentation to catalogue the physical appearance of the possessed and hysterical body while working at the Saltpêtrière.

${ }^{138}$ Quoted in Silverman, "Nature, Nobility, and Neurology", 173. Bernheim, although a contemporary of Charcot, often disagreed with his theories surrounding hypnosis. Both, however, were interested in the relationship between the unconscious and the conscious mind.
} 
self-projection, such as his Portrait Psychologique de l'Auteur of 1905 (fig.45), which reveals a sort of visual self-analysis. In this self-portrait, Mossa depicts a room filled with symbols of his creative motivations, fears and influences - which notably include a framed portrait positioned directly above the artist's head, featuring a modern woman (closely resembling the woman in Le Foetus and Le Système du Docteur Forceps) who wields a dagger and grips a small fetal skull. The framed landscapes that flank the portrait of the modern woman depict the Bridge of Sighs in Venice (which Mossa had painted during his travels in 1903) and a rural scene of Nice. The image of the threatening modern woman is situated between Venice - a city where Mossa had spent time training as an artist - and Nice - the French city with which Mossa most strongly identified. ${ }^{139}$ She is thus at the centre of his artistic vision and she arises from the artist's mind like a "mental projection" of his fears surrounding the state of the family. The Portrait Psychologique de l'Auteur casts Mossa as the archetypal suffering artist and on the wall, he includes a red handprint along with spatters of dripping red paint that signal his tormented (and bloodied) hand. This apparent fusion of paint and blood within his self-portrait suggests that Mossa's artwork was meant to address his own inner struggles, as well as the inner ruptures of society.

In a letter written in March of 1908 to his future wife, Charlotte-Andrée (who had expressed concern about marrying the young artist because of the often

${ }^{139}$ Soubiran, Gustav Adolf Mossa 1883-1971, 219. 
disturbing nature of his paintings), Mossa defended the sincerity of his artistic vision

with the following:

...je suis sans hésitations pour savoir vers quel but doit tendre l'art plastique.

Or vous avez semblé douter de ma sincérité, vous avez semblé envisager ce que vous avez vu de mon oeuvre comme le résultat de visions voulues étranges par désir d'épater le bourgeois alors que c'est la seule chose à laquelle je n'ai point pensé en travaillant. Jusqu'à ce jour je n'ai fait guère que ce que j'ai voulu tenacement; si tout cela a été voulu et pensé dans la solitude, tout ce que j'ai créé a germé en moi sous des influences psychologiques pressenties sinon vécues. ${ }^{140}$

His claim of creating images that arose out of personal psychological influences thus bespeaks at least a basic level of awareness for the new theories of the psyche that were becoming increasingly interested in the flow of influence between mind and image..$^{141}$

Mossa's images are thus situated within the cultural and psychological framework of the fin de siècle, as the fetus that he depicts in Le Système du Docteur Forceps, Le Foetus and La Madone manifests wider social, gendered and patriotic fears within the consciousness of the young artist. It is as if the multitude of pressing social concerns that centred on the fetus were internalized (and "intuited, if not lived") by

${ }^{140}$ Quoted in Soubiran, Gustav Adolf Mossa 1883-1971, 5-6. The passage translates as follows: “...I have no hesitations in knowing what goal art must aim for. However, you appeared to doubt my sincerity and you seemed to imagine that what you saw in my paintings was the result of willfully strange visions that were motivated by a desire to shock the bourgeoisie, but this is the only thing I was not thinking about at all while working. To this day, I have tenaciously done only what I wanted to do; if all of that arose from thoughts and desires born in solitude, then all that I have created germinated within me from intuited (if not lived) psychological influences"(my italics).

${ }^{141}$ Mossa's claim that "intuited (if not lived) psychological influences" motivated his art is somewhat disingenuous. His oeuvre clearly shows signs of the diverse influences that Mossa derived from areas of literature, visual culture and the work of other artists, among other things. However, his statement speaks to the artist's interest in using art as a means of projecting his inner thoughts and fears (despite the fact that such emotional "projections" were hardly without conscious cultural roots). 
Mossa. His works made use of the fetus as a symbol that conveyed a sense of fragmented masculinity (thereby signaling the threatened male individual). Whether or not Mossa consciously used the fetus as a direct symbol for his own fear of selfperil is, of course, a difficult matter to establish with certainty; but clearly, it was common within Art Nouveau to seek externalized symbols of the internal mind. In addition, the slight similarity in appearance that exists between Mossa's self-portrait in Portrait Psychologique de l'Auteur and the male figures within Le Système du Docteur Forceps and Le Foetus also hints at the artist's desire to create self-reflexive art that embodies his internalized and projected fears.

In this sense, the floating fetal bodies that hover overhead in Le Système du Docteur Forceps may possibly serve as the "projected inner visions" of the abortionist and the female patient, for they signal the morbid thoughts of the figures within the scene. On the one hand, then, the fetal bodies point to the ongoing shifts within visuality, which saw interior spaces filled with swarms of bodies, with spirits, and with embryos (as Huysmans put it). On the other hand, they evoke the psychological boundary between the subjective and objective, as they also suggest the projected idea of abortion, appearing here as a sort of "thought balloon" issuing from the doctor's cigar. Furthermore, the blurring of the ethereal fetus and/or thought-projection with the surrounding décor of the interior within Mossa's image recalls another level of internal projection: namely, that which had been attributed to the conflation of inner 
vision and interior space, and which had become a common feature of the modern Art Nouveau styles and decorations of the fin de siècle.

In Le Foetus, Mossa again integrates references to internality and projection, although in this case, the swollen head of the fetal corpse that floats within the glass vessel evokes (on at least one level) the tradition of maternal impressions as the cause for fetal monstrosity. As was noted above, the concept of maternal impressions related to the perceived permeability of the mind and body, as the womb was believed to be a site of dangerously porous flow wherein the physical signs of the mother's "degenerate" thoughts - in this case, of abortion - would be etched upon the body of the child within the womb and thus result in deformity. Although Mossa's image simultaneously references Christly salvation through his evocation of martyr symbolism, he nonetheless refers to traditions of the illicit "inner vision" of the mother, as his image embodies both the sacred and profane.

The relationship between the displayed fetus and the inner vision (and guilt) of the mother is underscored by the juxtaposition of the mother who peers into her own mirror reflection and the body of the aborted fetus. The woman's line of vision is overtly linked with the mirror: a symbol of vanity and selfishness. Her vision (in this sense) thus denotes the selfish female nature that was widely viewed to be a primary cause of abortions in pro-natalist arguments. Furthermore, as Stephen Pender notes in his study of human exhibitions, "monsters [were] conceived as mirrors in which we 
see our boundaries, our narcissism, or our questions about received images of self'. ${ }^{142}$ The dead fetus, then, reveals a clear externalization of her inner thoughts.

The transparent glass vessel that contains the fetus - which was characterized in chapter two as an inverted Virginal Vase of sorts - emphasizes this permeability and flow between the mother and fetus. Yet, Mossa's blurring of the internal and external also extends beyond the mother and the fetus, as he visually blends the fetal vessel and the mother's body with the surrounding décor of the room (much like the transparent fetal bodies found in Le Système du Docteur Forceps that decoratively merge with the room's interior). In this way, Mossa creates a fusion of spaces that draws on the concepts of projected inner vision and the relationship between internal decadence and its external manifestation.

In La Madone, the "fetus-as-projection" is articulated in a slightly different manner. For the pregnant Virgin, the fetus represents the materialization of the divine: the Word of God made Flesh within the mother's body and the Spirit incarnated. The fetus rests within the transparent window of the womb in a liminal space of inside and outside, ostensibly signifying the roles of both Christ and the Virgin Mary as mediators between humanity and the divine. The fetus, in this sense, represents a similar projection of inner vision - of divine inner vision - although in this case, the projected fetus is internalized within the protective womb of the

${ }^{142}$ Pender, "In the Bodyshop," 96. 
mother, while in both Le Système du Docteur Forceps and Le Foetus, it is externalized (and thus exposed).

Mossa's treatment of the fetus in La Madone shares an affinity with the work of Max Klinger, who depicts a similar sort of "fetal space" within his etching and engraving titled Awakening (fig.46) from his 1887-1903 Eine Liebe ("A Love") series. In this, Klinger signifies a young woman's realization of having become pregnant following a night spent with her lover by means of a ghostly fetus that floats like a reflection on a rounded, luminous mirror on the wall. Although in this case, the circular portal of the womb is projected as the prophetic mirror on the wall which reflects the woman's inner state, it seems likely that both Klinger and Mossa drew from the historical precedent of the medieval "maternal window" that reveals the Christ-in-utero, as well as the growing interest in a psychological interior. In a later image from the same cycle, Klinger depicts the death scene of the young woman (fig.47). Two figures hover over her body and one of them (presumably representing Death) whisks away a fetal corpse, thus suggesting that the woman's pregnancy resulted in either a still-born birth or a botched abortion. ${ }^{143}$ The fetus, within Klinger's images, seems to embody social tragedy and suffering, as he ultimately addresses the relationship between the emotional realities of sex, love and death. A similar interpretation has been made of Edvard Munch's Madonna (fig.48), which appeared in a series of lithographs from c.1895-1902. The image shows an

${ }^{143}$ Varnedoe, Graphic Works of Max Klinger, 84-85. 
eroticized Madonna, encircled in a pulsating halo-like aura and paired with both a frightened fetus and spermatozoa that appear within the decorative margins of the image. In current scholarship, Munch's depiction of the Madonna has been convincingly linked to the developing psychological theories of the projected inner psyche, as well as Charcot's documentation of the sexual fits of the female hysteric. Munch's Madonna appears with closed eyes, as if in the throes of an ecstatic and divine revelation that also resembles a state of sexual passion. Her ambiguous sexualdivine rapture has also been likened by Munch-scholars to Bernini's famous marble sculpture of The Ecstasy of Saint Teresa of c.1652 (fig.49), which similarly displays a conflation of divine revelation and embodied sensual experience. ${ }^{144}$

Munch's rather atypical representation of the Madonna and Child has been linked to a matrix of references, including the artist's preoccupation with prostitution, abortion, hereditary disease, and the "possessed" hysterical female body. Citing Munch's obsessions with madness, death and the dangerous nature of sex within modern culture and his own "free love" milieu in particular, Stephen Schloesser suggests that "the skeletal embryo - precariously balanced between life and death and framing the biological act of human love - might well convey the terror [Munch] felt towards the seeds of destruction contained within sexual pleasure". ${ }^{145}$ The moment conveyed by Munch, however, oscillates between the physical and the transcendent,

\footnotetext{
${ }^{144}$ Schloesser, "From Spiritual Naturalism to Psychical Naturalism," 75.

145 Ibid., 96; Cordulack, Edvard Munch and the Physiology of Symbolism, 60-63.
} 
the external and the internal, as it ultimately reveals the external manifestation of an inner vision - one which conflates sexual ecstasy, hysterical possession, and the sacred moment of this maculate reworking of the Immaculate Conception.

The gesture of the fetus within Munch's image also conveys a tension between sacred and profane meaning. While its crossed arms are initially suggestive of its huddled and fearful state, the gesture mimics the conventional response made by the Virgin Mary at the sacred moment of the Annunciation - a gesture that is also manifest in Mossa's La Madone. In iconographic traditions, Mary's crossed arms traditionally reflected her dutiful acceptance of motherhood and God's will. In this way, Munch's Madonna signals an imminent conception that will be maculate, not immaculate. Despite this, the title, the halo and the gesture of the fetus reference the Annunciation and the Immaculate Conception. His image thus suggests an inversion of sacred order (and iconography) that refers to the consequences of sexual freedom and simultaneously underlines the sanctity of the fetus. ${ }^{146}$

In Mossa's depictions of the fetus he emphasizes its innate position of marginality, permeability and flux - concepts which may have been partly inspired by Munch's placement of the skeletal fetus within the margin of the image. In considering the wider-reaching implications of Mossa's treatment of the fetal symbol as a way of expressing corporeal and spiritual boundaries, I now turn primarily to the

\footnotetext{
${ }^{146}$ Mossa's awareness of the images by both Munch and Klinger is quite likely, as both were prints which had been reproduced in several editions. (Munch's image was reproduced in five versions and Klinger's image (which was part of a ten-part cycle) was reproduced in four editions.
} 
works of both Mary Douglas and Julia Kristeva, which respectively consider the question of human boundaries within a much broader context.

In Purity and Danger (1966), the cultural anthropologist, Mary Douglas, addresses the nature of sacred boundaries and the symbolic transgression of those boundaries through defilement. She argues that the sacred is necessarily separated and protected from defilement, while those things which are in turn considered profane (namely the dirty, impure, or abnormal) are classified as such because they defy the boundaries or rules of containment which preserve the sacred and ensure proper social order. ${ }^{147}$ According to Douglas, because impurities defy the boundaries of order, they necessarily represent sources of danger. ${ }^{148}$

Douglas goes on to ascribe to the human body a particularly strong association with threatened social boundaries, as she suggests that "we cannot possibly interpret rituals concerning excreta, breast milk, saliva and the rest unless we are prepared to see in the body a symbol of society, and to see the powers and dangers credited to social structure reproduced in small on the human body". ${ }^{149}$ She posits that the dangers associated with the body lie specifically in its margins or boundaries, as these areas mark points of rupture and vulnerability. She states:

We should expect the orifices of the body to symbolize its specially vulnerable points. Matter issuing from them is marginal stuff of the most obvious kind. Spittle, blood, milk, urine, faeces or tears by simply issuing forth have

\footnotetext{
147 Douglas, Purity and Danger, 9.

148 Ibid., 48.

${ }^{149}$ Ibid., 142.
} 
traversed the boundary of the body. So also have bodily parings, skin, nail, hair clippings and sweat. ${ }^{150}$

In this sense, the aborted (and still bloodied) fetal corpse that is depicted by Mossa within Le Foetus represents the defiled boundaries of the body, as well as those of a defiled social order. It acquires the dangerous power that is attributed to blood, tears or other excreted bodily wastes, as it is flesh removed from the body - from none other than the dangerous and porous womb of the mother.

Douglas's arguments on the dangers associated with the body's margins resonate within Julia Kristeva's theoretical text entitled Powers of Horror, from roughly two decades later, wherein she examines the "abject" boundaries of human existence. In this, Kristeva concerns herself with similar questions of transgression that also touch on concepts of impurity and defilement. She describes the term "abject" as that which separates itself from its containing borders and, as such, represents the ruptured borders of the self. She states:

These body fluids, this defilement, this shit are what life withstands, hardly and with difficulty, on the part of death. There, I am at the border of my condition as a living being. My body extricates itself, as being alive, from that border. Such wastes drop so that I might live, until, from loss to loss, nothing remains in me and my entire body falls beyond the limit - cadere, cadaver. ${ }^{151}$

Kristeva suggests that the corpse - "the most sickening of wastes" - represents the ultimate 'border', as it signifies the abjection of death. ${ }^{152}$ She describes the human

\footnotetext{
150 Douglas, Purity and Danger, 150.

${ }^{151}$ Kristeva, Powers of Horror, 3.

152 Ibid.
} 
corpse as a site of abject horror because of its symbolic transgression of the living human body.

Kristeva's description of the abject resembles Douglas's account of the defiled body, as she too suggests that abjection hinges on disorder within social systems. She notes:

It is thus not lack of cleanliness or health that causes abjection but what disturbs identity, system, order. What does not respect borders, positions, rules. The in-between, the ambiguous, the composite...Any crime, because it draws attention to the fragility of the law, is abject, but premeditated crime, cunning murder, hypocritical revenge are even more so because they heighten the display of such fragility. ${ }^{153}$

In this sense, the fetal corpse in Le Foetus reveals the abject through both its relation to the criminal act of abortion (which disrupts social, moral and legal codes) and its embodiment of death: that final, horrifying transgression of the boundaries that separate absence from presence. Its blood, in this sense, represents the symbolic blood - and rupture - of society and nation. In Mossa's image of Le Système du Docteur Forceps, the depicted fetus is also abject in the Kristevian sense because it hovers within an intermediary, unfixed state between presence and absence, as a means of signaling the deliberate crime of abortion - an act which in turn disturbs order. In this way, the coupled images of Le Foetus and Le Système du Docteur Forceps capture the transpiring abortion, thereby revealing an abject event that reflects the state of social instability and uncertainty of France.

${ }^{153}$ Kristeva, Powers of Horror, 4. 
While Mossa uses the fetus as a symbol for order and disorder, he also makes use of other symbols to convey similar concepts. His depictions of anti-Semitic stereotypes and his allusions to witchcraft, in particular, are rooted in the concern about social and religious margins. In her discussion of the marginal, threatening areas found within social structures, Mary Douglas argues that witches, for example, symbolized a wider sign of rebellion and disorder, suggesting that they "are social equivalents of beetles and spiders who live in the cracks of the walls and wainscoting...the kind of powers attributed to them symbolize their ambiguous inarticulate status". ${ }^{154}$ Although Mossa's references to witchcraft are subtle, they indeed seem to linger in the "cracks" (so to speak) of his image, with visual references that appear within the decorative interior of the abortion chamber and which hint at the insidious disorder therein.

Kristeva's account of the social dangers attributed to Jews within anti-Semitic discourse is in a similar vein, as she links the developing figure of the threatening Jew with concepts of abjection. She states:

The Jew becomes the feminine exalted to the point of mastery, the impaired master, the ambivalent, the border where exact limits between same and other, subject and object, and even beyond these, between inside and outside, and disappearing - hence an Object of fear and fascination. Abjection itself. He is abject: dirty, rotten. ${ }^{155}$

\footnotetext{
${ }^{154}$ Douglas, Purity and Danger, 127.

155 Kristeva, Powers of Horror, 185. In her analysis of anti-Semitic discourse, Kristeva examines the WWII-era work of the French writer, Louis-Ferdinand Céline.
} 
Kristeva's statement thus identifies the abject danger of the Jew with his ambivalent position on the borders of existence, as these borders represented areas of social fragility and rupture.

In chapter two of this thesis, Mossa's representation of the Jewish doctor/abortionist was linked with the anti-Semitic rhetoric of the fin de siècle that surrounded widespread fears of degeneracy and corruption. The truncated male figure within Le Système du Docteur Forceps was therein linked to the alleged "Jewish threat" against masculine power. Additionally, because the body of the truncated male figure is visually severed, and because he rests specifically on the outer margin of the image - on the very border between the seen and the unseen - he embodies the threatening status of the Jew as a dangerous (and abject) transgressor of ordered boundaries.

Kristeva's positioning of the Jew at the limits of human borders resonates within the physical appearance of Doctor Forceps. His robes that bear a pattern of human skulls and bones present a "blurring" of the inside and outside of the body, whereby his external appearance reveals an internal structure (both through an Xray-like indication of the body's internal anatomy and through the symbolic meaning of the tiny skulls that pointed to the abortionist's moral interior). This oscillation between the doctor's inside and outside mirrors the relationship between his external physiognomy and his internal degeneracy - a point which was also noted in chapter 
two. The effect of Doctor Forceps' outward appearance is therefore one of ambiguity, wherein his interior is difficult to separate from his exterior.

Ambiguity is also to be found in Mossa's image of Le Foetus. If we consider Le Système du Docteur Forceps as the embodiment of complete corruption and La Madone as its ideal, sacred alternative, then Le Foetus rests somewhere in between these two poles, with an image of the fetus that is ultimately not indicative of pure abjection, but which shifts between being a symbol of disorder/rupture and being a symbol of the renewed/sacred. Here, Mossa employs the defiled, abject and aborted fetus as a means of pointing to its non-horrific reverse. The fetus, in this sense, reveals both desecration and consecration through its marginal and abject state.

This reciprocal relationship between defilement or abjection and the sacred is, in fact, touched upon by both Douglas and Kristeva. Douglas argues that the perceived organizing boundaries that serve to separate the sacred from the profane (and thus preserve order) in fact reveal moments of slippage wherein the pure becomes impure, or vice versa. Her discussion of how the sacred is necessarily separated from the impure leads Douglas to examine purifying rituals that enable order to be restored following a transgression. She describes how systems of pollution and purification often include ritual transitions and rites of passage that alter the state of power, and she argues that although danger lies in these areas of transition, rituals 
possess the potential for rebirth and renewal. ${ }^{156}$ Here, Douglas refers to ritual acts that possess the power to counter pollution through cleansing and purification. In many cases, the very objects that were initially identified as unclean and defiled paradoxically become sacred through this process.

This notion of purifying ritual is central to Le Foetus, as here the glass vessel which displays the fetal corpse - that horrifying embodiment of abject rupture and defiled order - doubles as a sacred reliquary or monstrance. This apparent reversal of the profane may illustrate the ritual of rebirth that Douglas outlines. In particular, Mossa's allusions to the Eucharistic Host and the martyred body within Le Foetus emphasize this concept of spiritual rebirth and salvation.

Mossa's presentation of the aborted fetus within the reliquary vessel draws on the very nature of religious relics, which were typically the "discarded bits" (so to speak) of dead saints. The Christian tradition of displaying sacred relics involved the ritual purification of the abject blood or body parts of the corpse, which rendered the horrific signs of death into transcendent signs of salvation. The bloodied fetal corpse, in this sense, reveals a conflation of the abject and the sacred wherein both realities are concurrently relevant. This coexistence of opposites mirrors the sacred power bestowed upon the once-horrifying bits of flesh, hair, or blood of martyred saints within religious tradition.

${ }^{156}$ Douglas, Purity and Danger, 119-120. 
The purifying nature of the glass vessel of transparent liquid that contains the body of the aborted fetus/martyred relic may additionally draw upon the powerful role of water within cleansing rituals of renewal - a point to which Douglas draws particular attention in her discussion of purification. She refers to Mircea Eliade's writings on water as a traditional dissolving agent, wherein, according to Eliade: ...everything that has happened ceases to exist; nothing that was before remains after immersion in water, not an outline, not a 'sign', not an event. Immersion is the equivalent, at the human level, of death at the cosmic level, of the cataclysm (the Flood) which periodically dissolves the world into the primeval ocean. Breaking up all forms, doing away with the past, water possesses this power of purifying, of regenerating, of giving new birth... 157

It is difficult to identify definitively the liquid within Le Fetus reliquary vessel (since displayed fetal specimens found within medical jars were usually submerged in alcohol or another such preserving agent), but if Mossa ultimately intended the fetus to represent a site of transition between the profane and the sacred, it seems possible that the reliquary jar of liquid may, in part, signify the cleansing, purifying water that dissolves past defilement and restores order. This is not to say that Mossa's image represents the aborted fetus solely as a positive sign of rebirth, but rather, that he intentionally contrasts, straddles and blends the sacred and profane implications of its image. This ambiguity reveals how the fetus is at once a sacred object defiled and a defiled object made sacred.

157 Quoted in Douglas, Purity and Danger, 199. She cites M. Eliade, Patterns in Comparative Religion (London, 1958), 194 
Mossa's references to the rites of the Catholic Mass also bolster the possibility that he was using the fetus to symbolize both death and rebirth, both the profane and the sacred. For example, his allusions to the monstrance and the Eucharistic Host (found in both Le Foetus and La Madone) point to the Catholic doctrine of transubstantiation that was central to the liturgical rites of the Lord's Supper. In this rite, the bread and wine taken in communion are miraculously transformed into the body and blood of Christ, thus illustrating a ritual conversion of the abject corpse into a sacred reminder of salvation. This transformation conflates matter with spirit and allows for a coexistence of everyday bread and wine with a more profound level of spiritual interiority. ${ }^{158}$

In reflecting on the nature of Biblical sin in relation to the sacred, Kristeva addresses the power of Christ's body to purify and restore transgression through the ritual of communion. ${ }^{159}$ This concept of transformative (and restorative) ritual is also discussed by Elaine Scarry in The Body in Pain. She suggests that the power of religious artifacts hinges on the "remaking" of human suffering that renders the site of loss into one of transcendence. ${ }^{160}$ Georges Bataille, too, addresses the reversal of transgression that occurs in the event of sacrificial death, as he states that "here life is mingled with death, but simultaneously death is a sign of life, a way into the

\footnotetext{
${ }^{158}$ Cullmann and Leenhardt, Essays on the Lord's Supper, 52.

${ }^{159}$ Kristeva, Powers of Horror, 119.

${ }^{160}$ Scarry, The Body in Pain, 292.
} 
infinite". ${ }^{161}$ The notion of transformative defilement is central to Christ's sacrificial death, as it meant a transcendent rebirth that purified human sin. By subtly conflating the aborted fetus with Christ in Le Foetus, Mossa arguably attempts to symbolically purify the abject, to restore order, and to salvage what has been destroyed, thus referencing the transformative and fluid space of religious ritual.

The image of the purifying, Immaculate womb of the Virgin in La Madone also embodies a restorative, divine counterpart to the image of the aborting mother of modern society. Mossa's depiction of the living body of Christ within the womb hints at the earthly manifestation of His body, both as the Eucharist and as the Church itself. In these forms, Christ and the Word of God are internalized and reborn within the body of the worshipper. Mossa's image of La Madone directly conflates these incarnations of Christ, as the internalized, fetal Christ is aligned with the Church and is conflated with both the monstrance-womb and the repeated word of "ALLELUIA" - the textual signifier of the Eucharistic rites.

In another work by Mossa from 1906, entitled Et Ne Nos Inducas In Tentationem (fig.50), the artist again illustrates a synthesis of sin and salvation, as he depicts a bleeding human heart containing the body of a man, curled up in a fetal position. The heart is, in turn, contained within a circular portal akin to that which frames Mary's womb in La Madone. Encircling the portal are the words Et Ne Nos Inducas In Tentationem, meaning And Lead Us Not Into Temptation - a phrase that

${ }^{161}$ Bataille, Erotism, 91. 
derives from the Lord's Prayer. ${ }^{162}$ In this case, temptation is embodied in the figure of the threatening modern woman - the antithesis of good motherhood. Dressed in black, the towering nouvelle femme appears alongside a miniscule church as she sinks her claw-like fingers into the "fetal heart", causing blood to issue forth. This bleeding heart is immediately suggestive of the iconographic tradition of the Sacred Heart of Christ, which consisted of the visual display of Christ's physical heart as a symbol for both His bodily suffering and His love for humanity.

In Et Ne Nos Inducas In Tentationem, the conflation of the bleeding heart with the fetal position of the male figure emphasizes the helplessness and powerlessness of mankind at the hands of female temptation, while simultaneously alluding, by means of the conflation of fetus and Sacred Heart, to the rebirth of mankind that is possible through Christ's death. The issuing of blood from the sacred heart thus evokes a reciprocal relationship between the sacred and profane, as the blood indicates on one hand an abject rupture of corporeal (and social) borders while, on the other, it illustrates the sacramental blood of Christ that offers salvation and renewal.

Mossa's citation here of the divine Word - the textual warning against temptation - that frames the site of sacred and profane rupture closely mirrors his use of the word "ALLEULIA" in La Madone. The words, in this case, are fused with the

\footnotetext{
162 Matthew 6:13. The entire phrase in the scripture reads: "And lead us not into temptation, but deliver us from evil".
} 
bleeding heart of Christ, with the fetal symbol, and with the body of the New Woman. In this way, Mossa arguably creates a reminder that Christ's suffering is embodied in the Words of God and that these Words represent the threshold between rebirth and damnation.

In many ways, Et Ne Nos Inducas in Tentationem and La Madone share key affinities: both refer to the sacred "internal body" made visible, both invoke the fetus in doing so, and both include background churches and Christian inscriptions, be they from the Lord's Prayer or the Mass. However, Et Ne Nos Inducas in Tentationem shows the viewer the temptation he should avoid: the modern Temptress and daughter of Eve. La Madone, conversely, rejoices (ALLELUIA) in Christ's incarnation in Mary - the "New Eve" who purifies Eve's sin.

The aptness of the fetus to function as a symbol for the desecrated and consecrated borders of existence arises from its intrinsic link with the productions of the mother's body - that primordial site of both destruction and birth, the ambivalence of which can be traced back to the writings of Plato, Aristotle and Hippocrates. Indeed, in Kristeva's discussion of the nature of abjection, she identifies the mother's body - and specifically, the interior of the mother's womb - as an originating source for the "desirable and terrifying, nourishing and murderous, fascinating and abject". ${ }^{163}$ Since the mother's womb was itself a site of eternal flow and permeability between life and death, sin and salvation, order and disorder, and

${ }^{163}$ Kristeva, Powers of Horror, 54. 
purity and pollution, the fetus (whether inside or outside of the womb's boundaries) necessarily existed within these maternal borders. 


\section{Conclusion}

Within art historical scholarship of recent years there has been a growing interest in treating the work of long-ignored and marginalized artists, in order to unlock new doors to the past and uncover the stories that existed outside the traditional art historical canon. In many ways, my research falls within that initiative, as relatively little has been written about Mossa's work to date. The images examined within this thesis are situated within a rich milieu of visual culture that includes decorative and fashionable trends of the fin de siècle, political satires and cartoons, religious art and artifacts, and medico-scientific objects and images. As a result, Mossa's fetal images are highly revealing of the ideas, attitudes and debates that informed fin-de-siècle visuality. This project has accordingly sought to develop more fully than heretofore the rich iconographical and iconological implications of Mossa's imagery.

Mossa's art, however, presents several challenges to contemporary academic analysis. Although he was a competent artist, Mossa was (and is) far from being considered an important, "great artist" with unique talent. He is more "the last Symbolist" than the originator of a new style, more rearguard than avant-garde. This thesis has not attempted to evaluate or comment on the aesthetic merit of his art, as my interests lay in understanding the themes and issues that he treated, rather than the degree of skill or stylistic innovation with which he treated them. I have approached his production more as visual culture than as "great art". I do, however, 
find Mossa to be a fascinating iconographer. His style, while not "progressive", is recognizably individual. Nevertheless, the nature of Mossa's subject matter may be anathema to contemporary sensibilities, as his paintings reveal overtly misogynistic, pro-natalist and anti-Semitic views. A principal purpose of mine has been to demonstrate the pervasive presence of these views within Mossa's work and to illustrate the historical framework that gave rise to them. In this, my intention was neither to condemn nor to defend Mossa's controversial values, but rather to shed light on how these ideas were shaped and how the relationship between idea and image was constituted.

In many respects, Mossa's artwork does invite censure, but this was not the objective of my undertaking, which was instead to understand the context and broader implications for the imagery that he created. Moreover, in attempting to reveal the complexities underlying historical constructions of morality, I have considered it more apt to strive for a neutral presentation, insofar as that is possible. Mossa's views (however reprehensible one may find them) arose from a long history of fears about gender, identity, morality, religion and nation, which continue to this day. In fin-de-siècle France, the root of these concerns lay in the apprehensive male psyche. The importance of the fetus as a symbol for nationhood, therefore, lay in its direct associations with gender, power and order within a threatened patriarchal structure. 
Mossa's images shed light on the way in which systemic fears took on physical shape in France, as they were internalized and externalized through bodies of disorder and fragmentation. The body of the fetus came to be inscribed by widereaching and nuanced social forces that were fueled by fears of degeneration and decay, the rise of both Jewish influence and abortions, and the changing position of women within both modern society and the home. However, in Mossa's artwork, the fetus signified at once transgression and convention, disorder and order. Like the newly visible microbes that represented an unlocking of invisible realities, the fetus in Mossa's work existed in a liminal space within the boundaries of contained and orderly society, within the very womb of the mother country and within the very heart of French identity. 


\section{Figures}

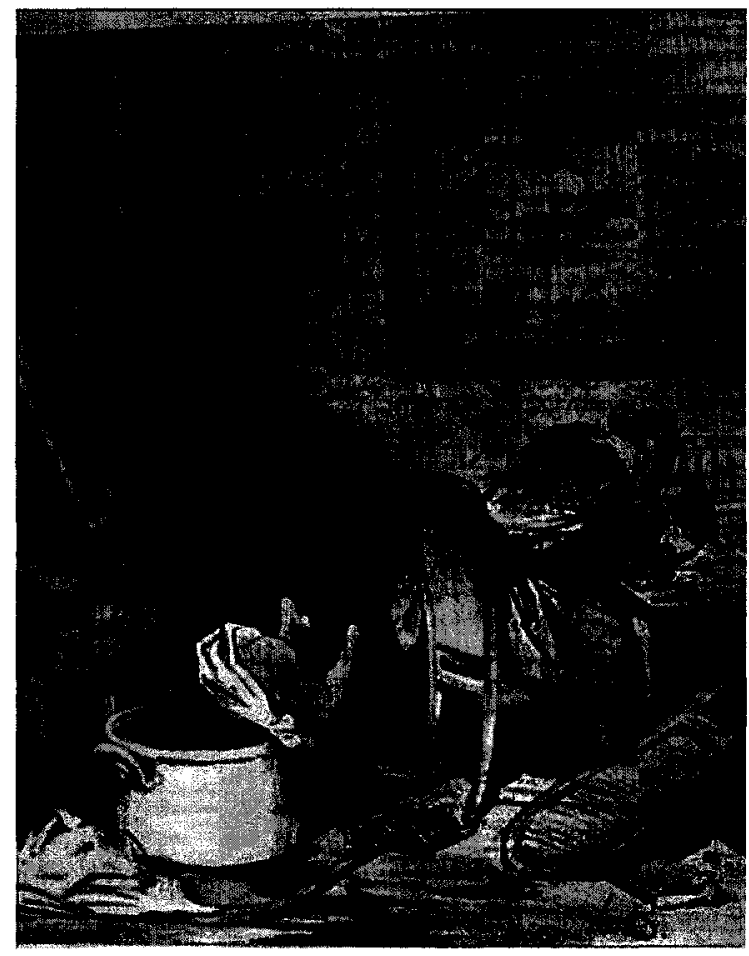

La mère est dans le feu de la composition, l'enfant est dans l'eau de la baignoire!

Figure 1. Honoré Daumier, from his bas bleus lithograph series, published in Le Charivari in 1844.

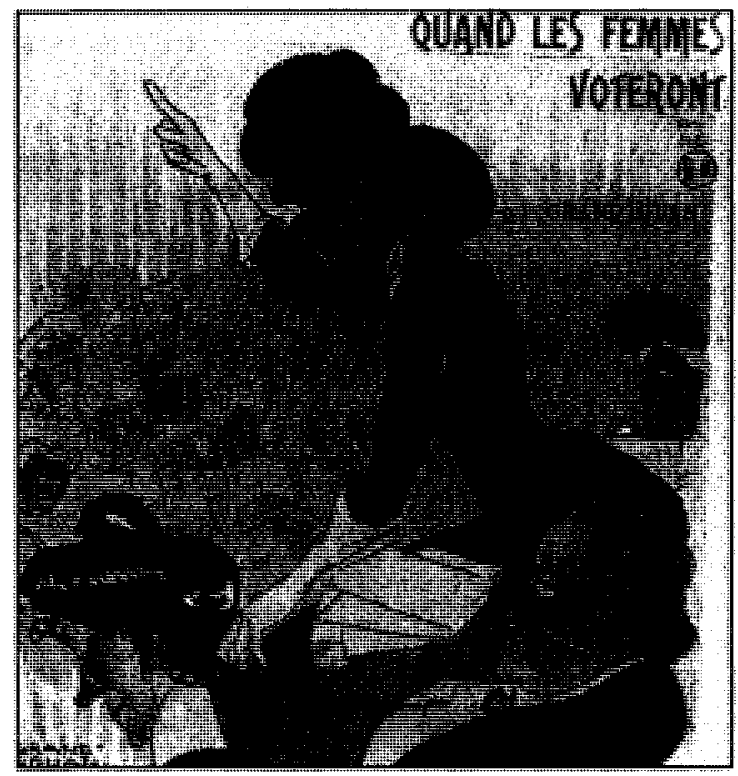

Figure 2. Drawing by Grandjouan from L'Assiette au beurre, published June 61908. 


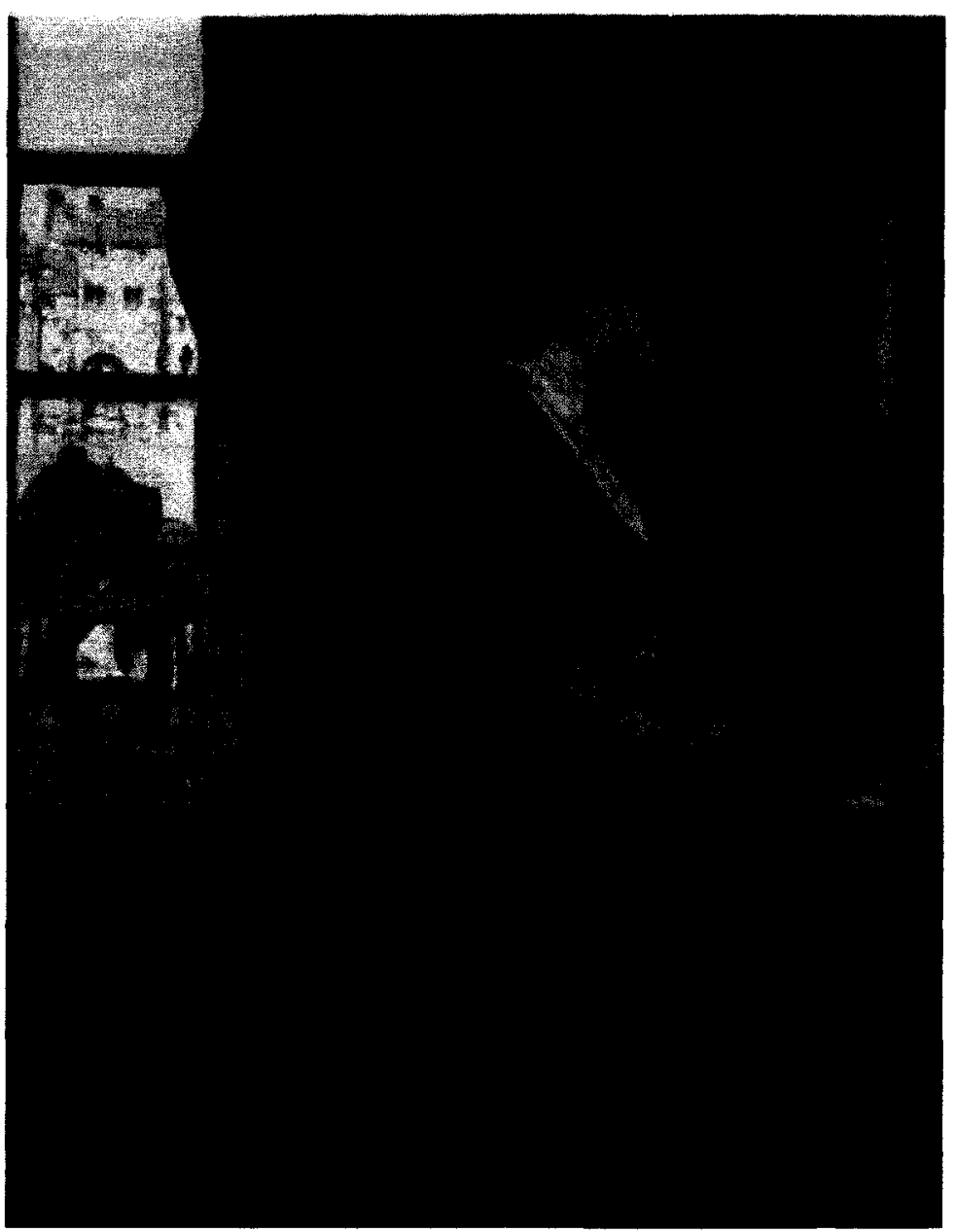

Figure 3. Gustav Mossa, Judith, 1906 (watercolour). 


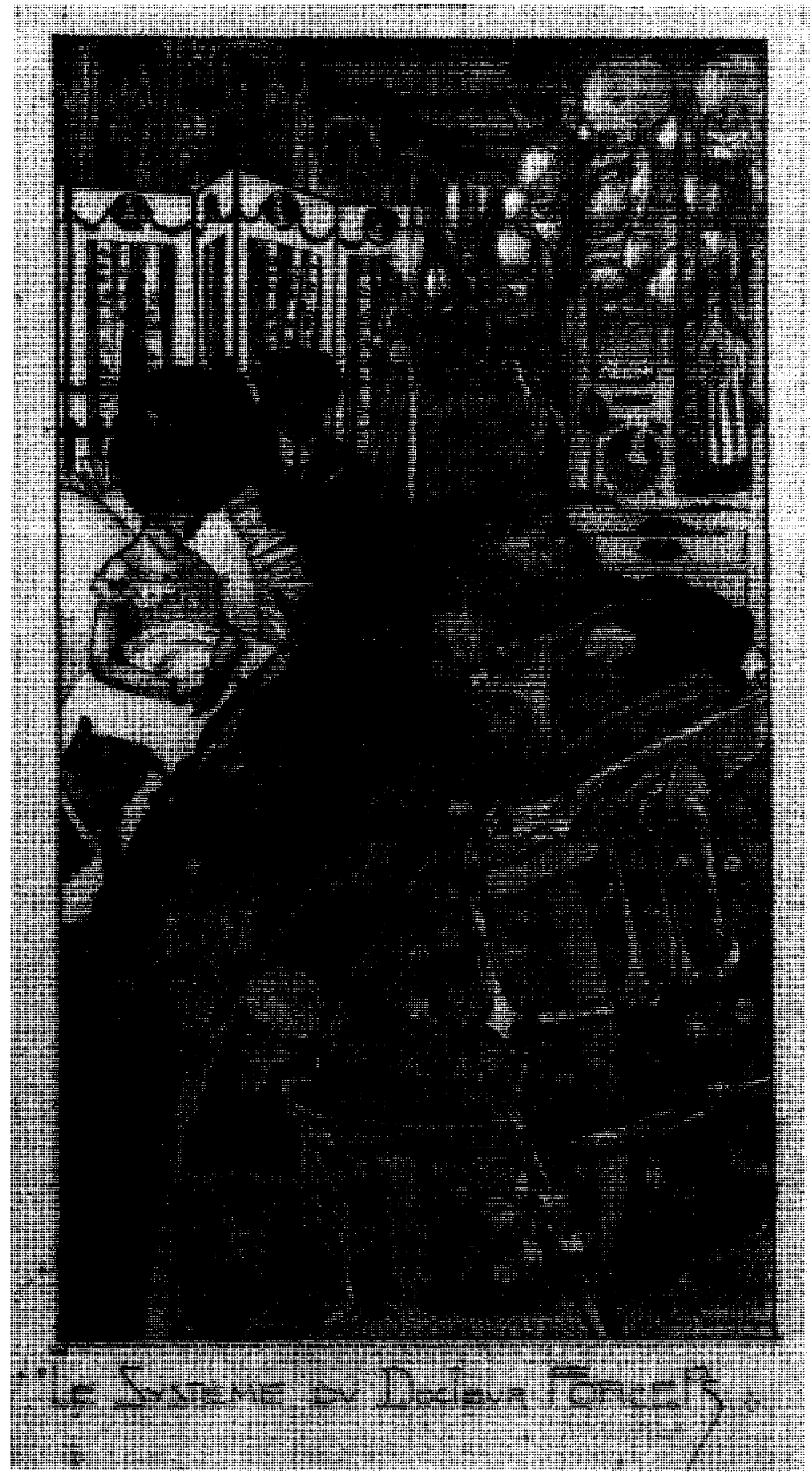

Figure 4. Gustav Mossa, Le Système du Docteur Forceps, 1905 (watercolour). Colour reproduction provided by the Musée des Beaux Arts (Jules Chéret), Nice. 


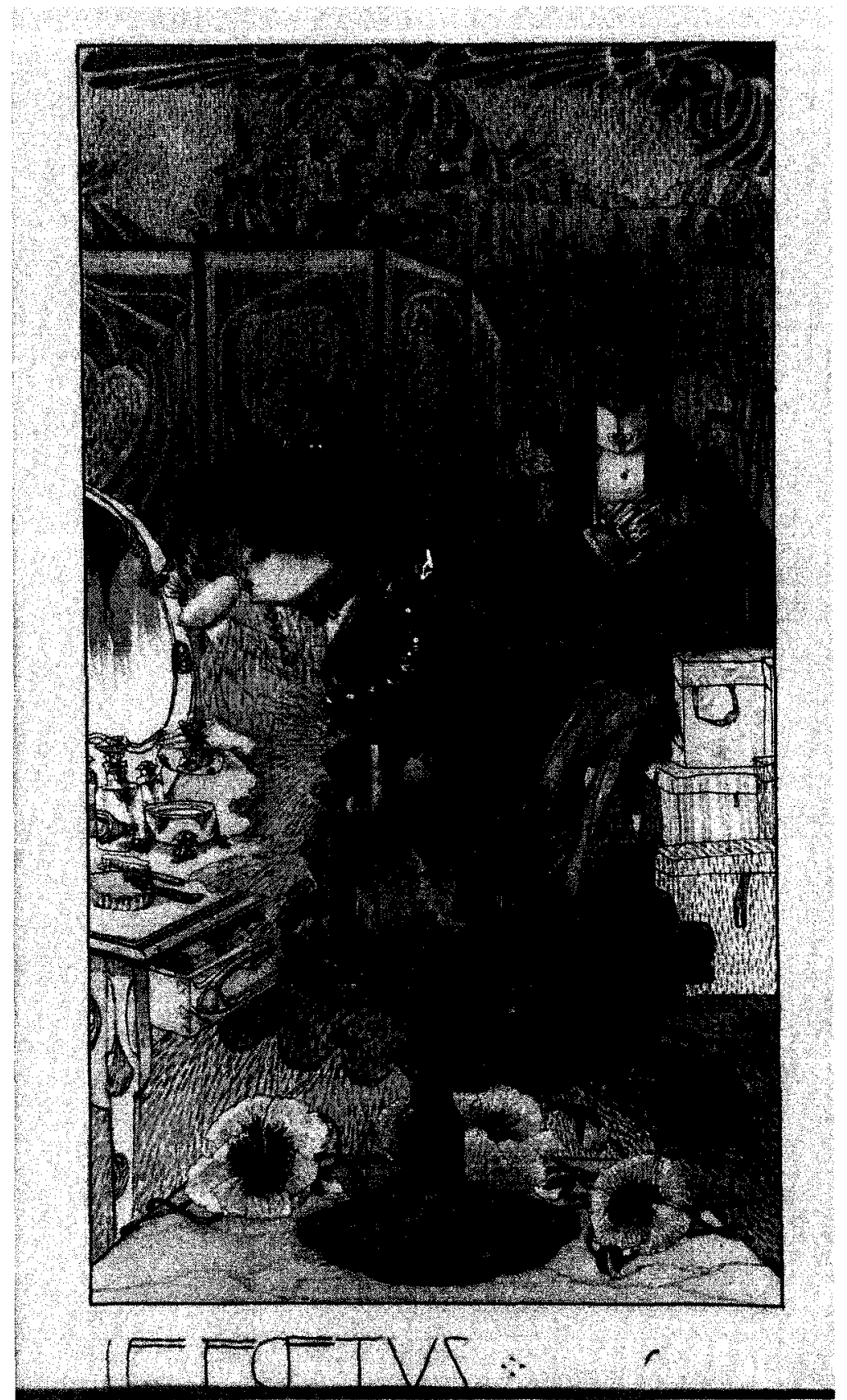

Figure 5. Gustav Mossa, Le Foetus, 1905 (watercolour). Colour reproduction provided by the Musée des Beaux Arts (Jules Chéret), Nice. 


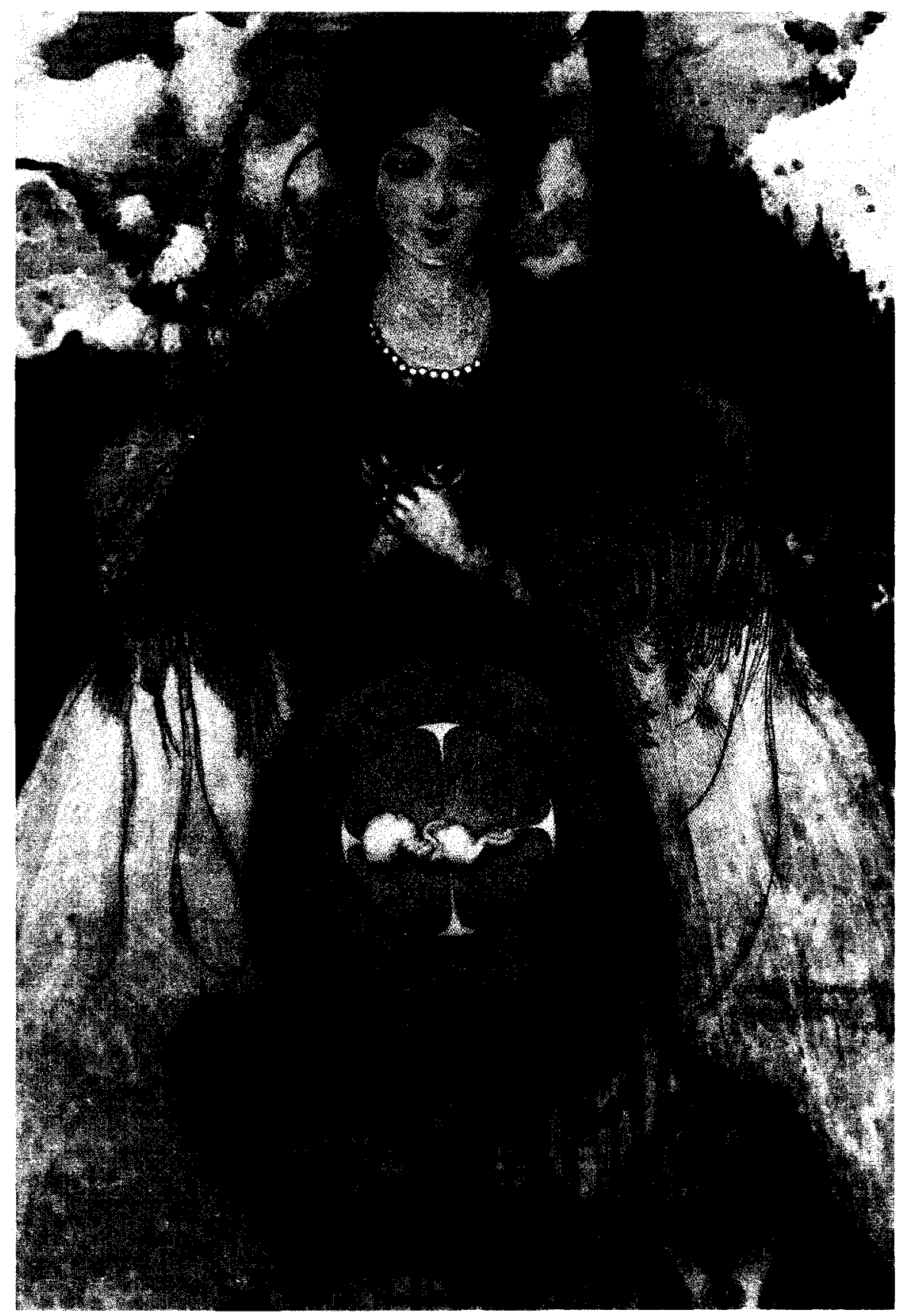

6. Gustav Mossa. La Madone, 1907 (watercolour). 

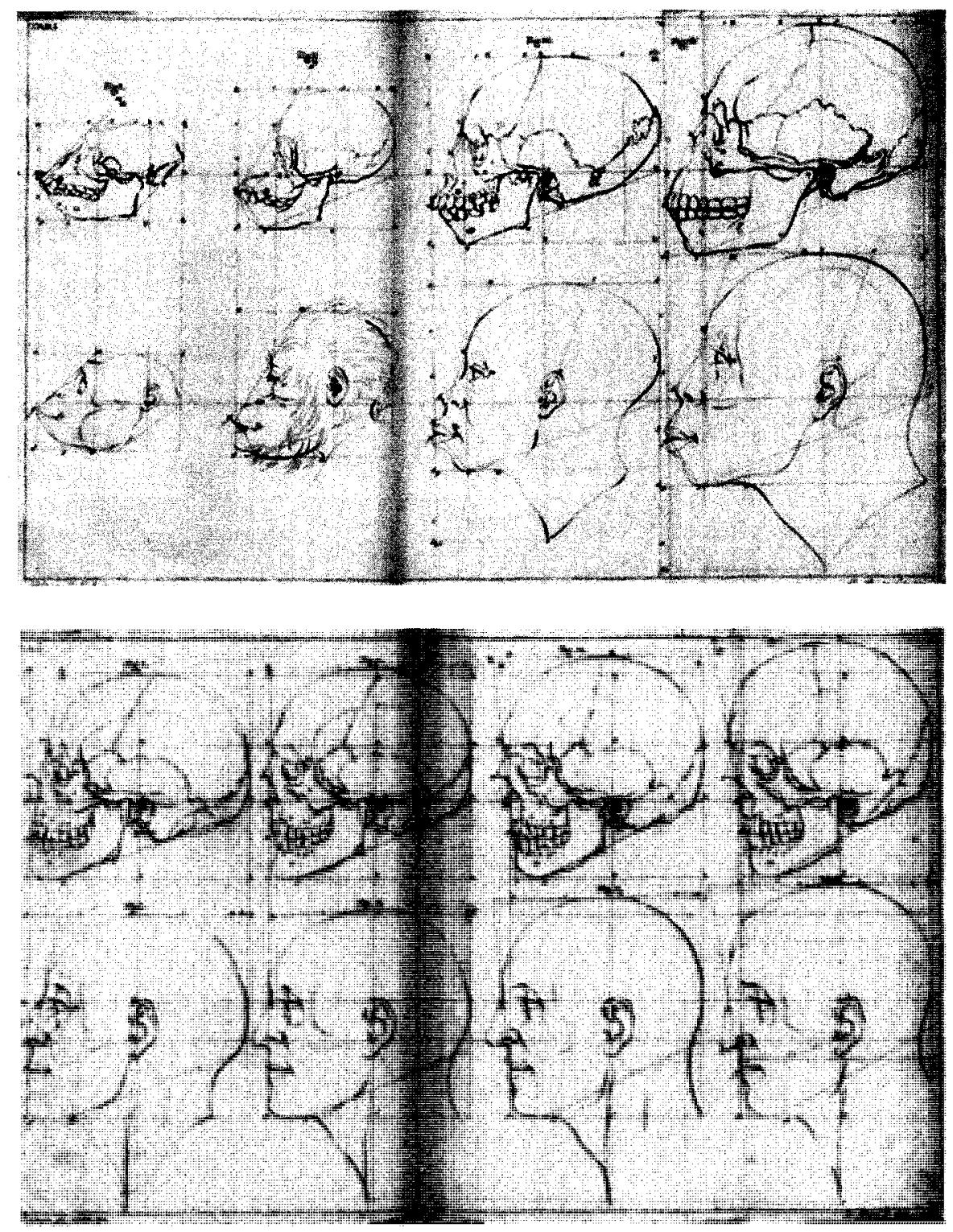

Figure 7. Petrus Camper, Drawings showing the evolution of facial traits, 1791. 


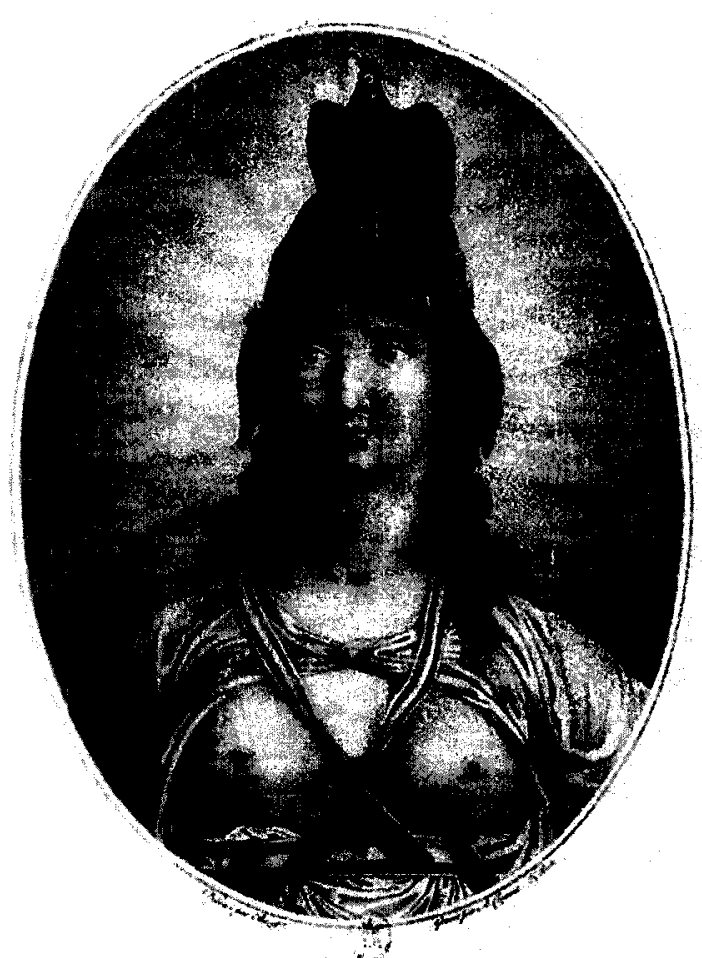

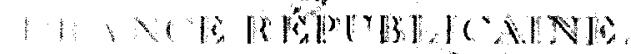

Figure 8. Alexandre Clément, Republican France/Opening her Breasts to All the French, 1792.

Figure 9. Honoré Daumier, The Republic, 1848 (oil on canvas). 


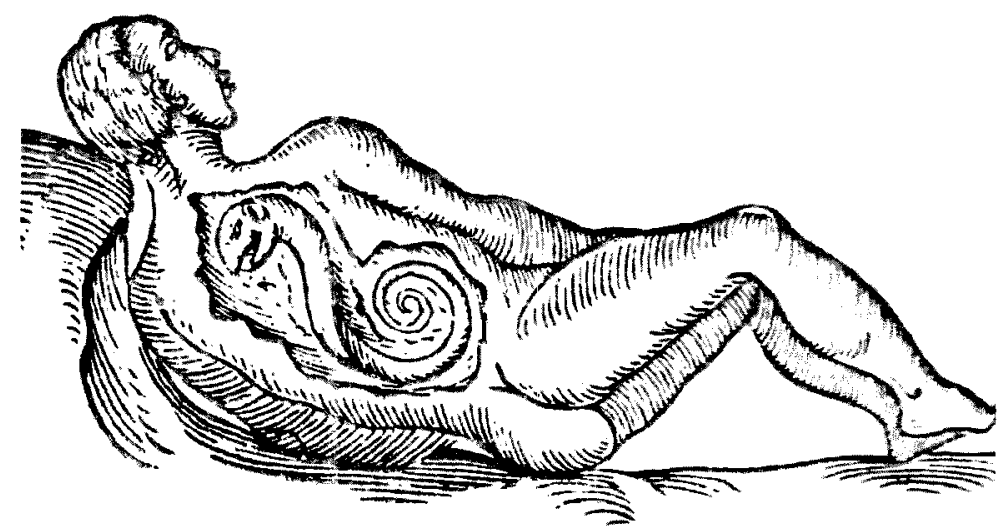

Figure 10. Ambroise Paré, Illustration from On Monsters and Marvels. figure of a child born with a live serpent in its back, $16^{\text {th }}$ century.

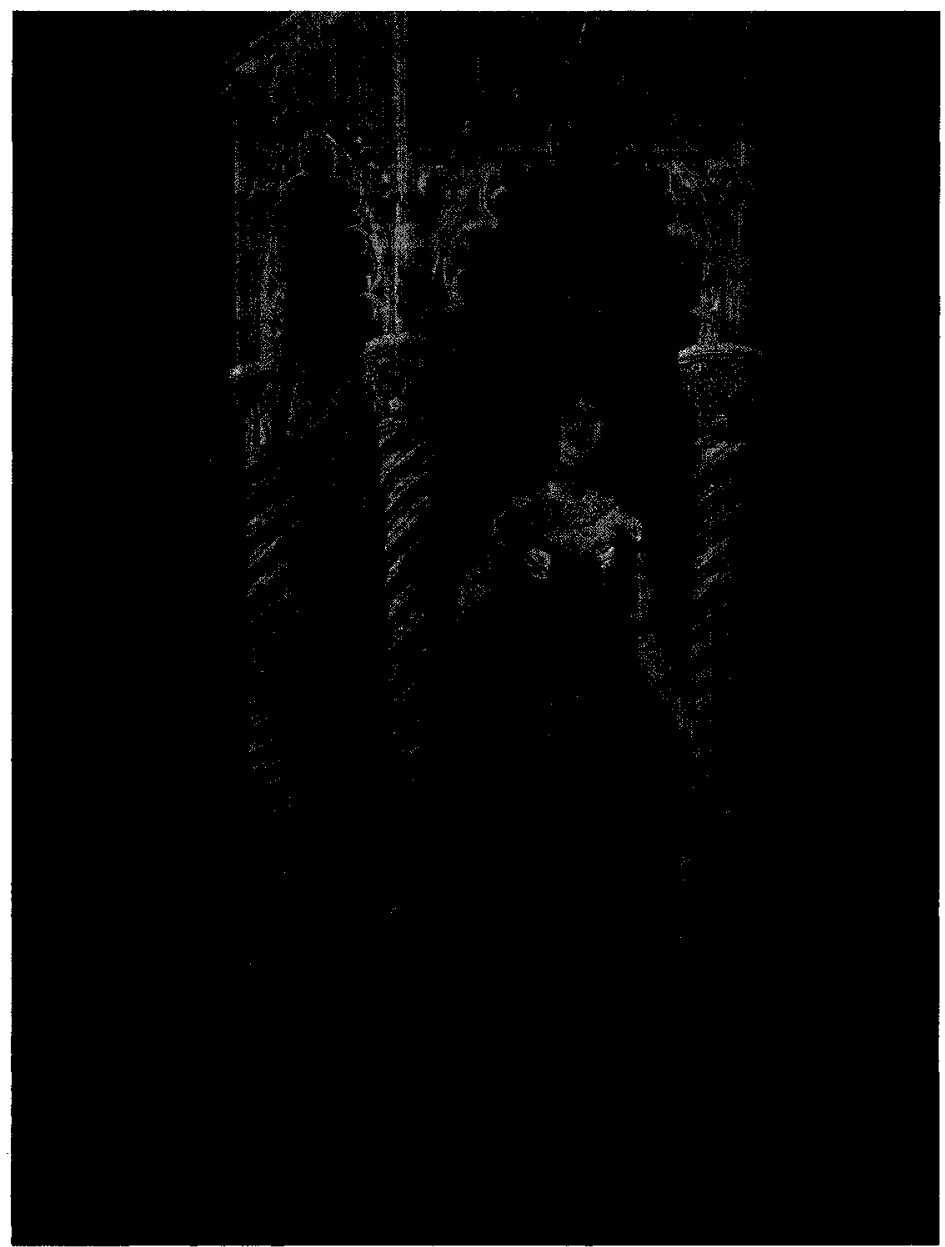

Figure 11. Gustav Mossa. L'Araignée, 1903 (unfinished oil painting on canvas). Author's photo, taken with the permission of the Musée des Beaux Arts (Jules Chéret), Nice 


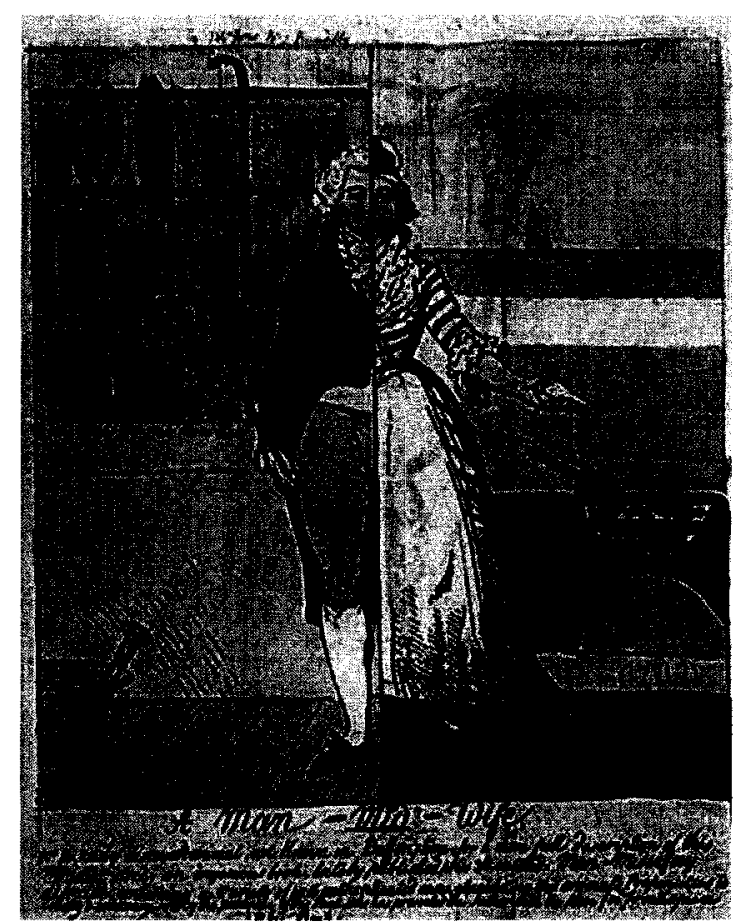

Figure 12. Anon., illustration from Man-Midwifery Exposed, 1793

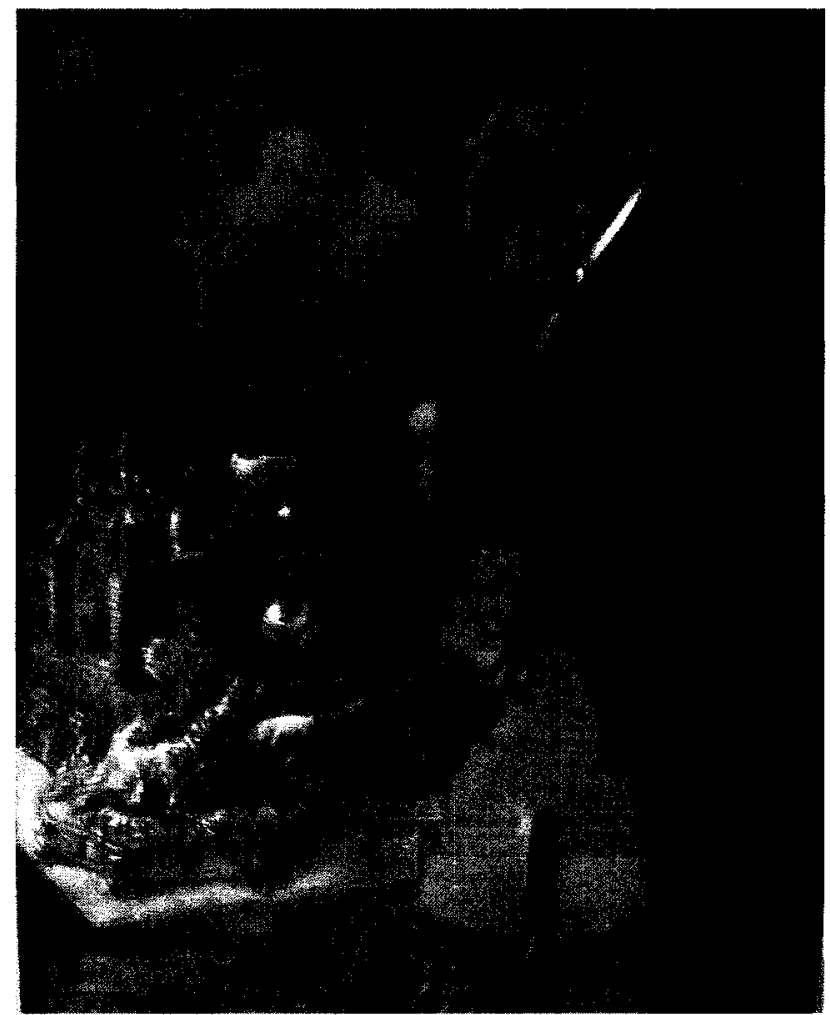

Figure 13. Gustav Mossa. Israel, 1907 (oil on canvas).

Author's photo, taken with the permission of the Musée des Beaux Arts (Jules Chéret), Nice 


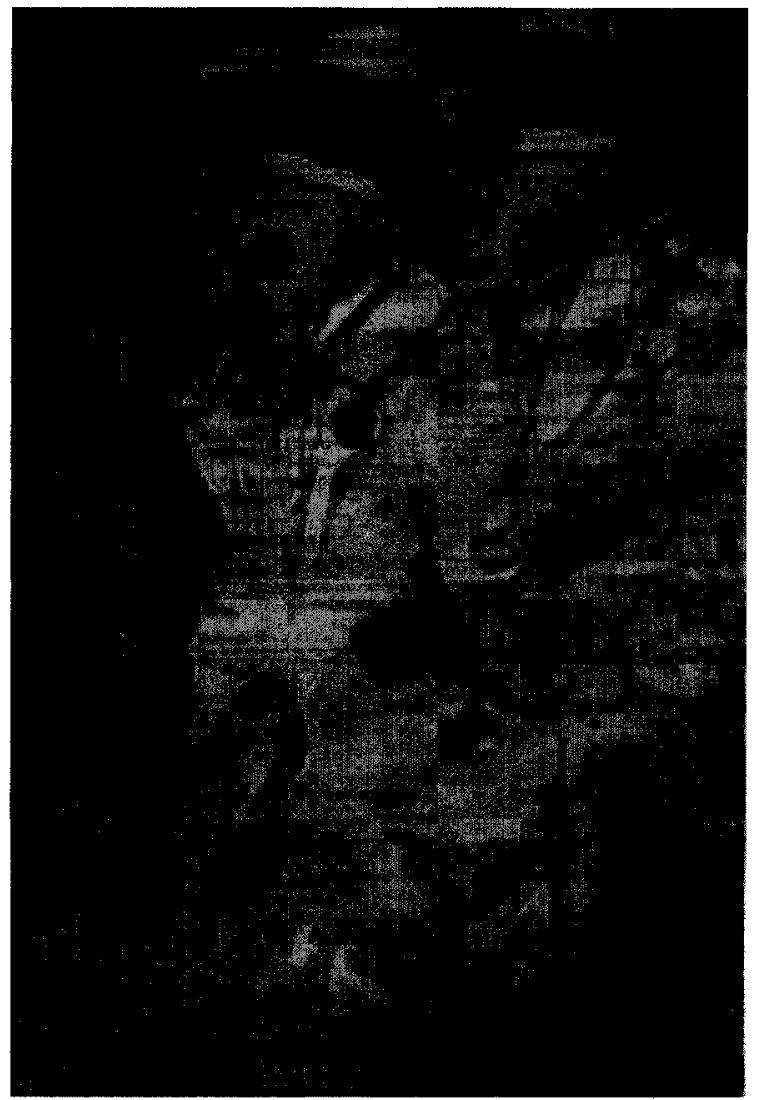

Figure 14. Gustav Mossa, Les Quatres Evangelistes, 1906 (watercolour).

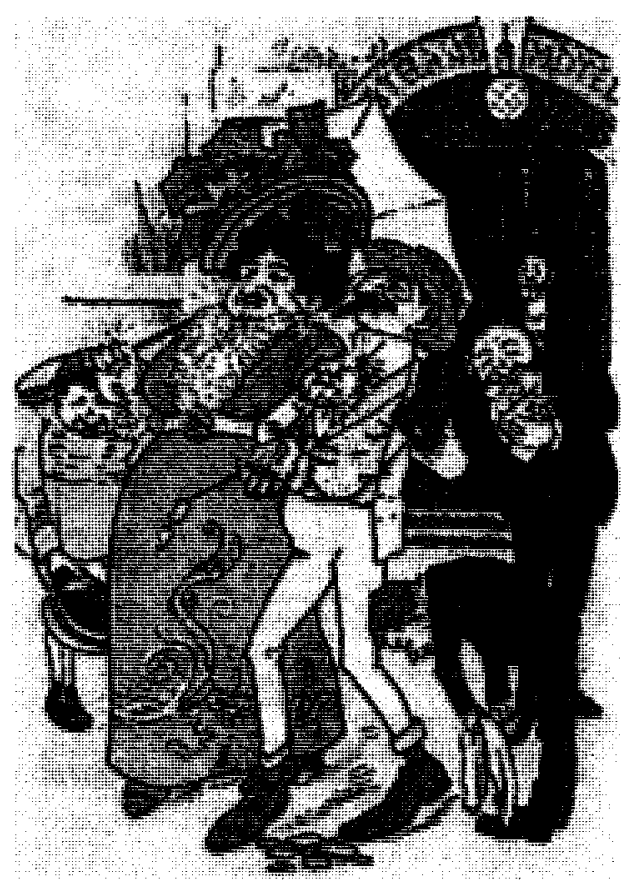

Figure 15. Anon., anti-Semitic postcard (German origin), late-19 ${ }^{\text {th }}$ century. 


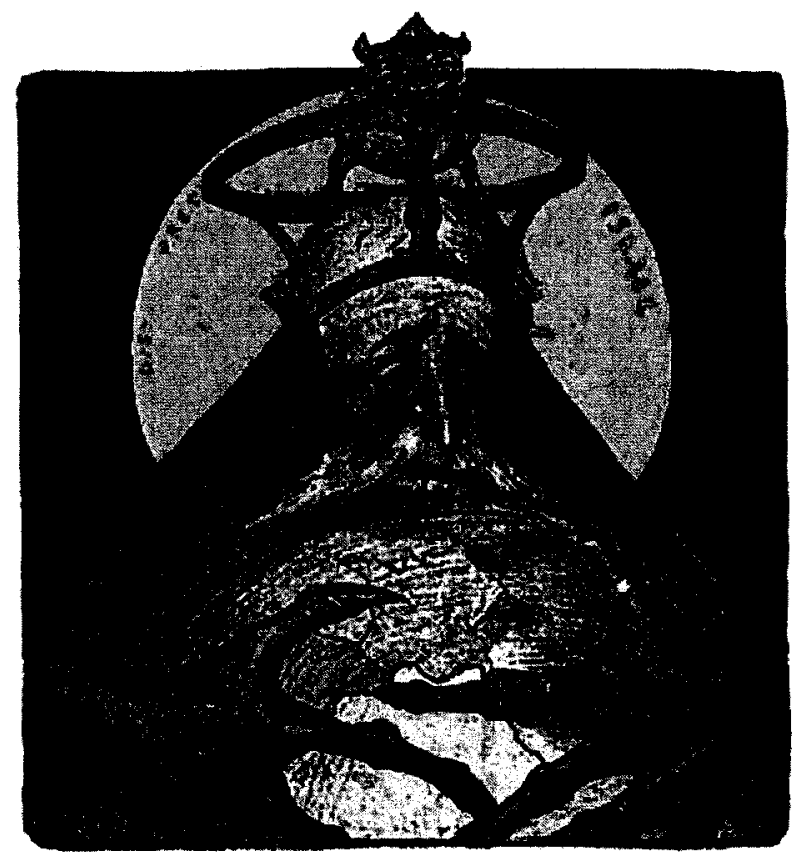

Figure 16. Charles Léandre, Rothschild, 1898 (giclée print).

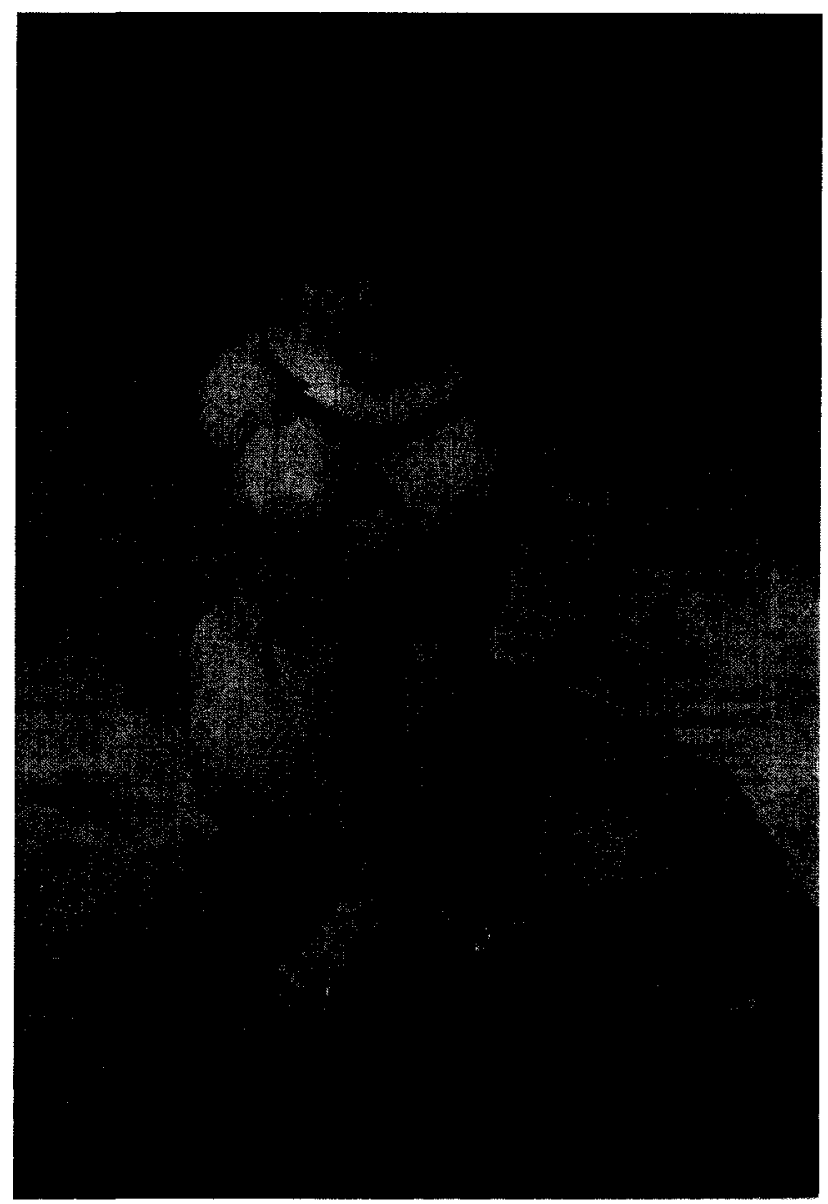

Figure 17. Gustav Mossa, Elle, 1906 (oil on canvas). 


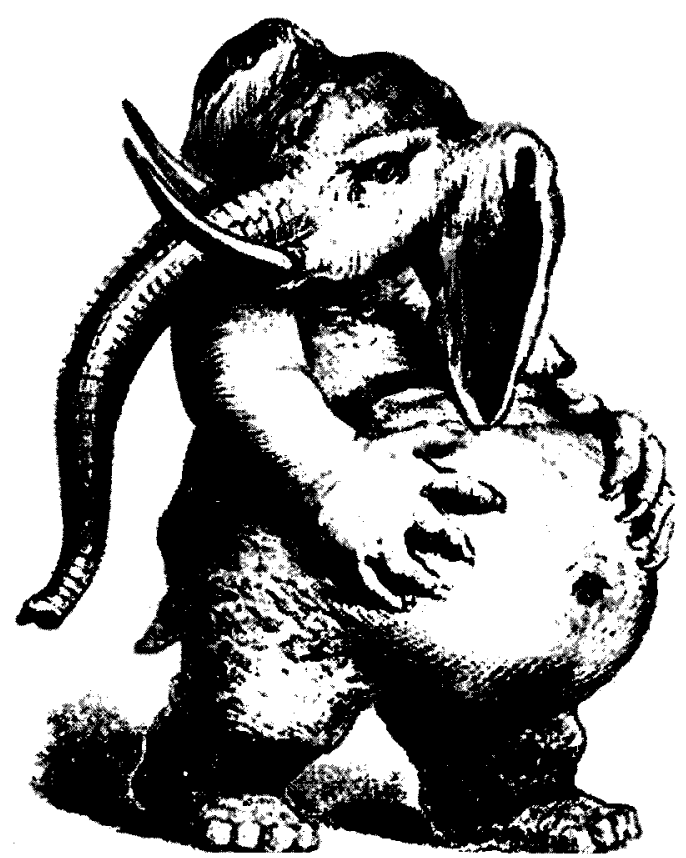

Figure 18. Collin de Plancy, Illustration of Behemoth, 1852.

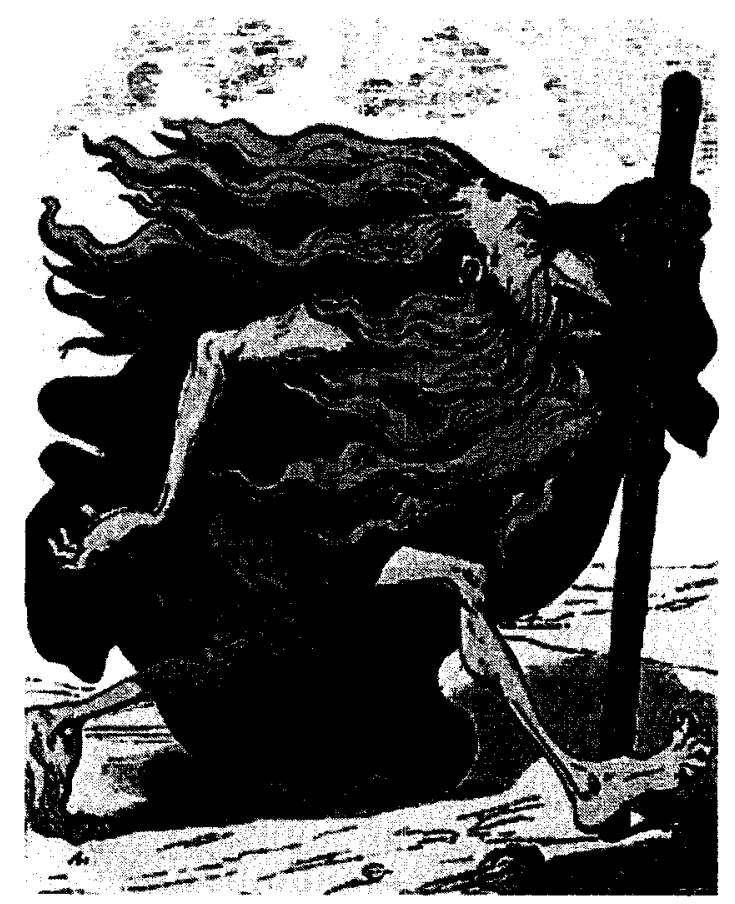

Figure 19. Gustave Doré, The Wandering Jew, 1852 (woodcut). 


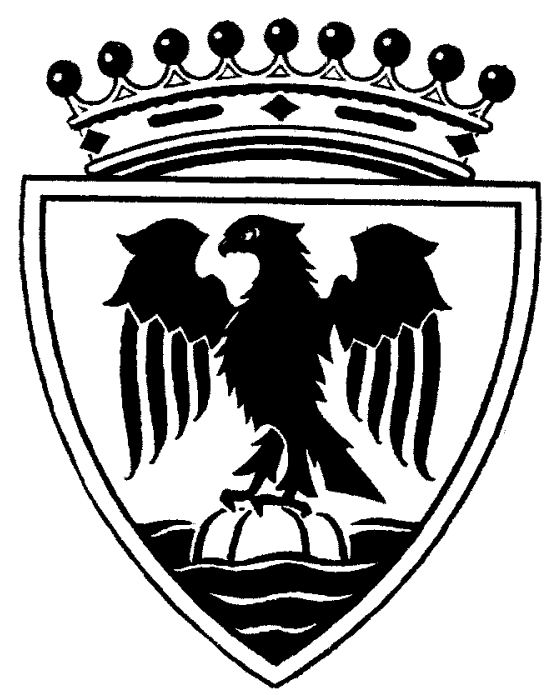

Figure 20. Banner of arms for Nice, depicted on the Centenaire du Rattachement de Nice (1960), which features a crowned eagle with spread wings.

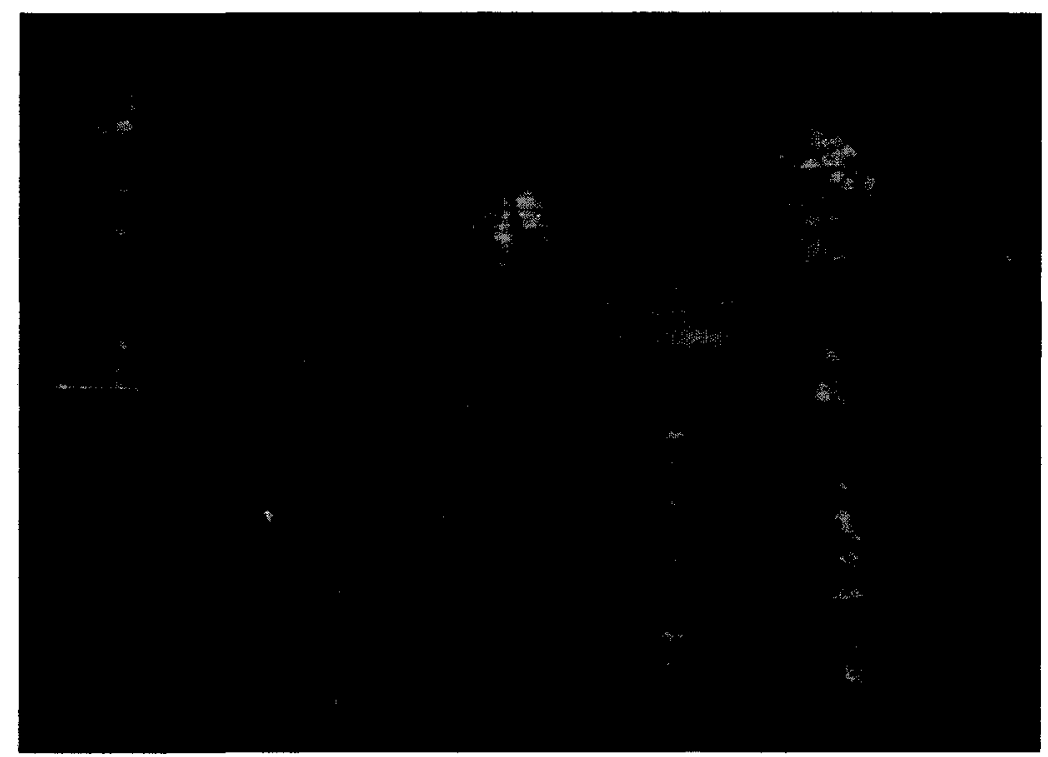

Figure 21. Collection of reliquaries and monstrance vessels from the Chapelle de la Miséricorde, Nice (author's photo). 


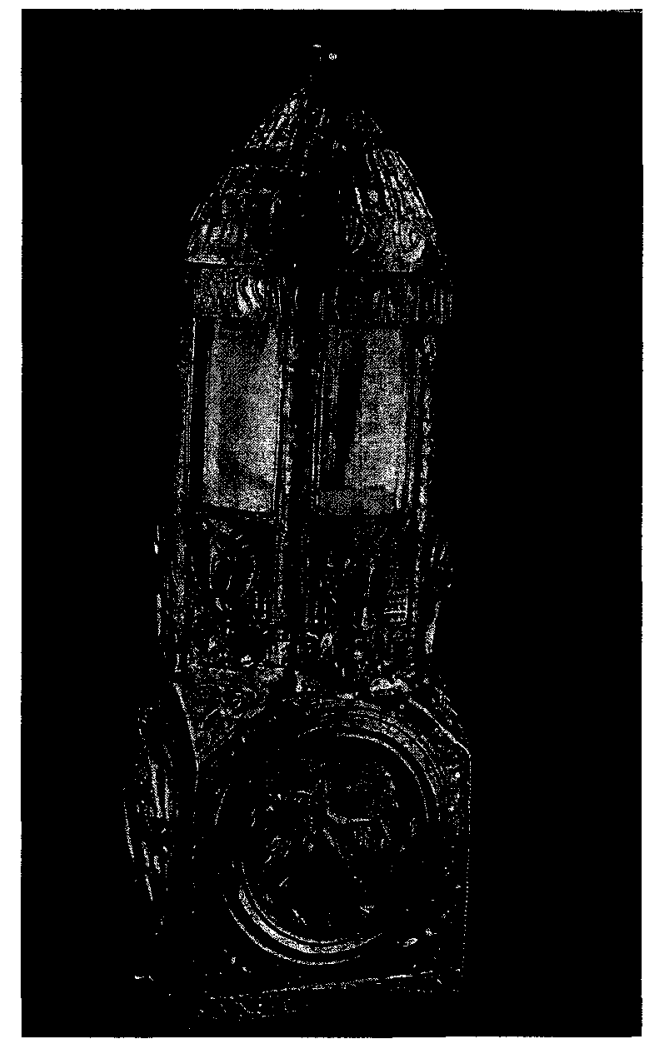

Figure 22. Lanterne de Bégon reliquary of Saint Vincent, $11^{\text {th }}$ century.

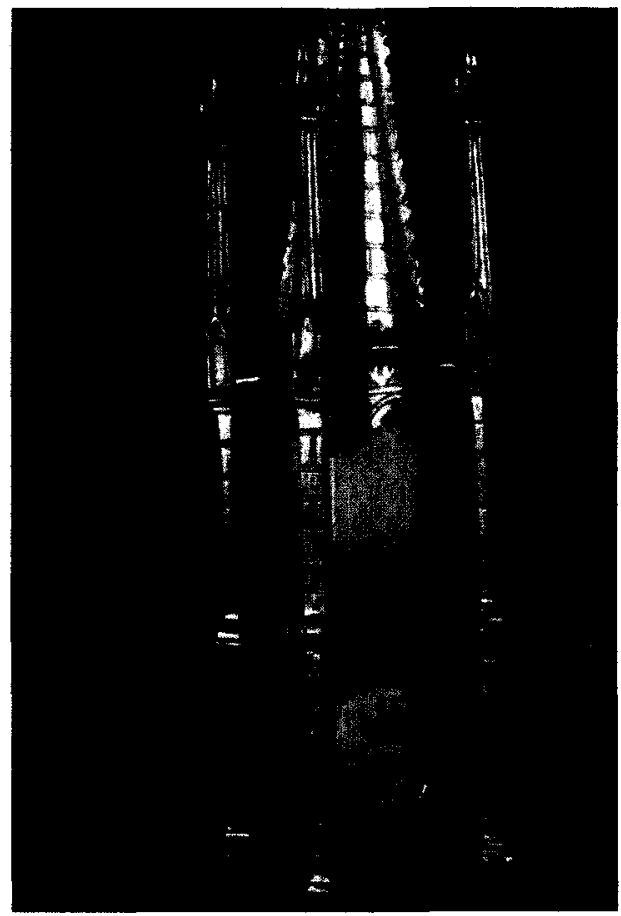

Figure 23. "Tower reliquary" of Saint George, $14^{\text {th }}$ century. 

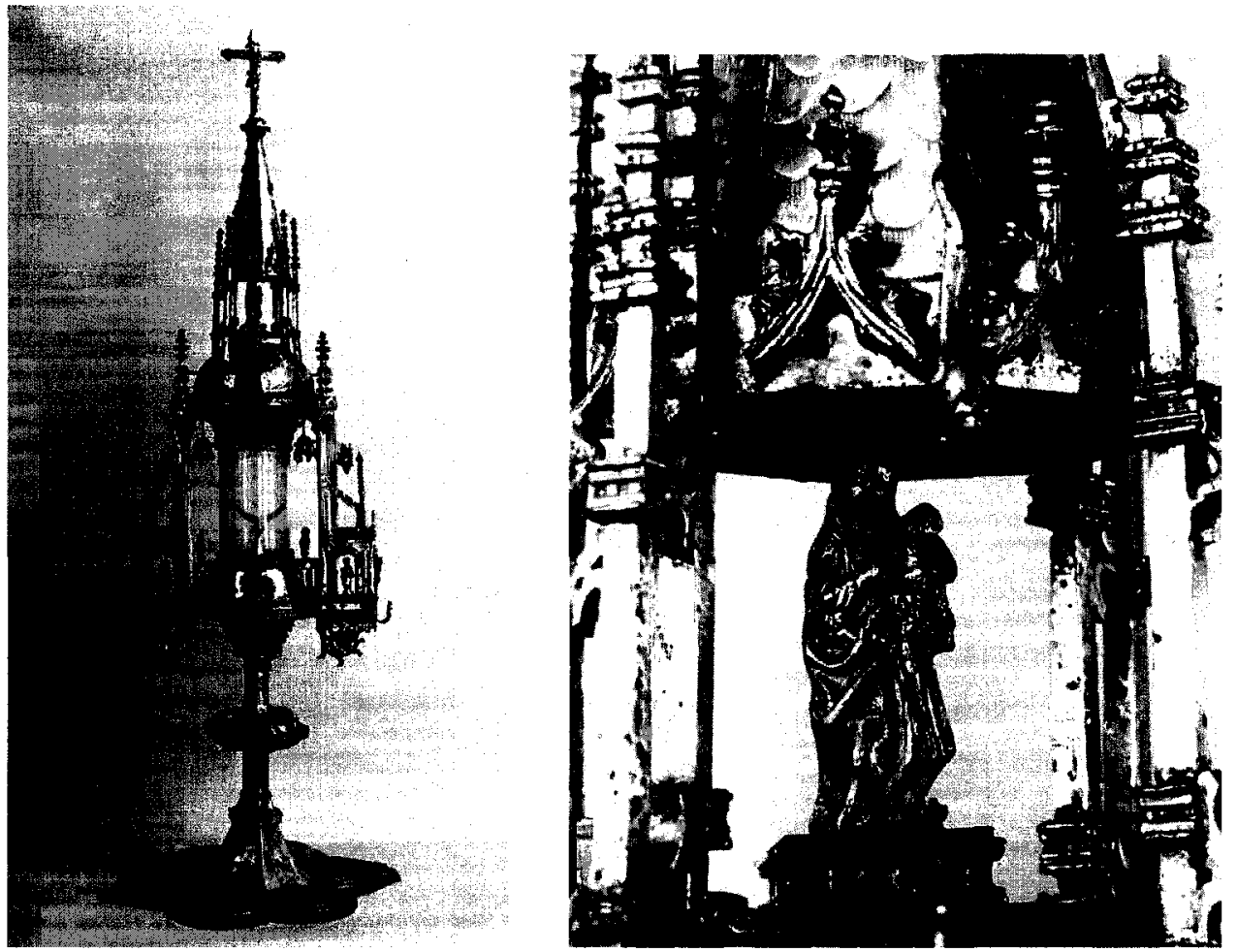

Figure 24. Gilded copper monstrance and detail of Madonna and Child decoration, $15^{\text {th }}$ century.

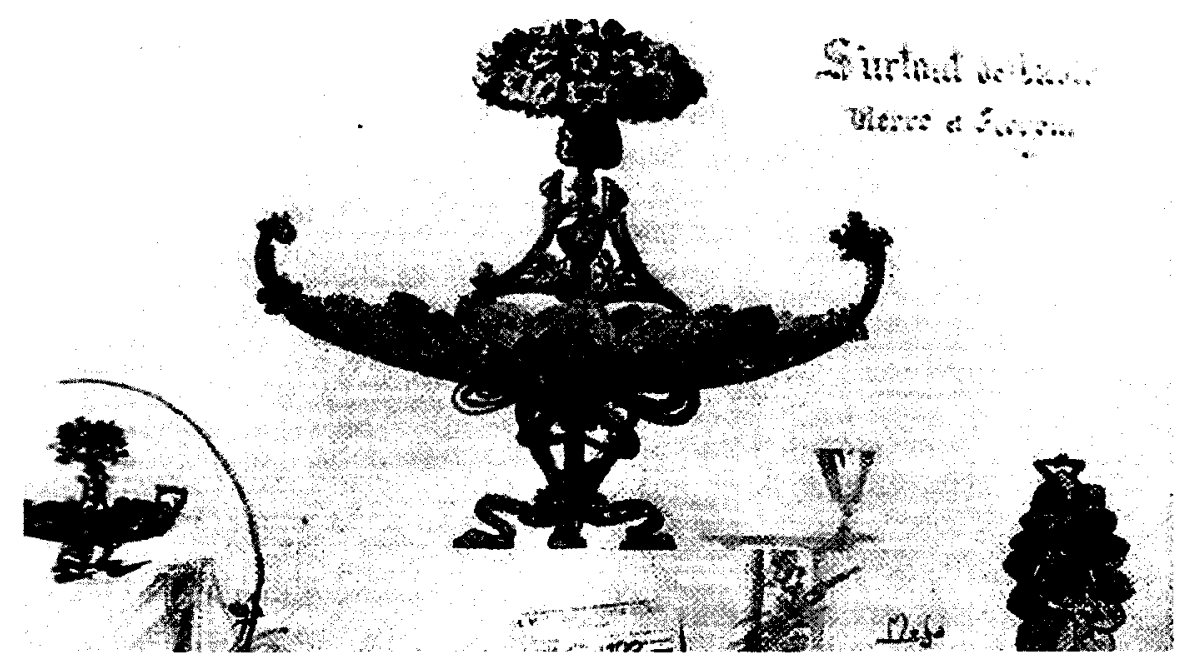

Figure 25. Gustav Mossa, sketches of religious vessels, 1900 (ink on paper). 


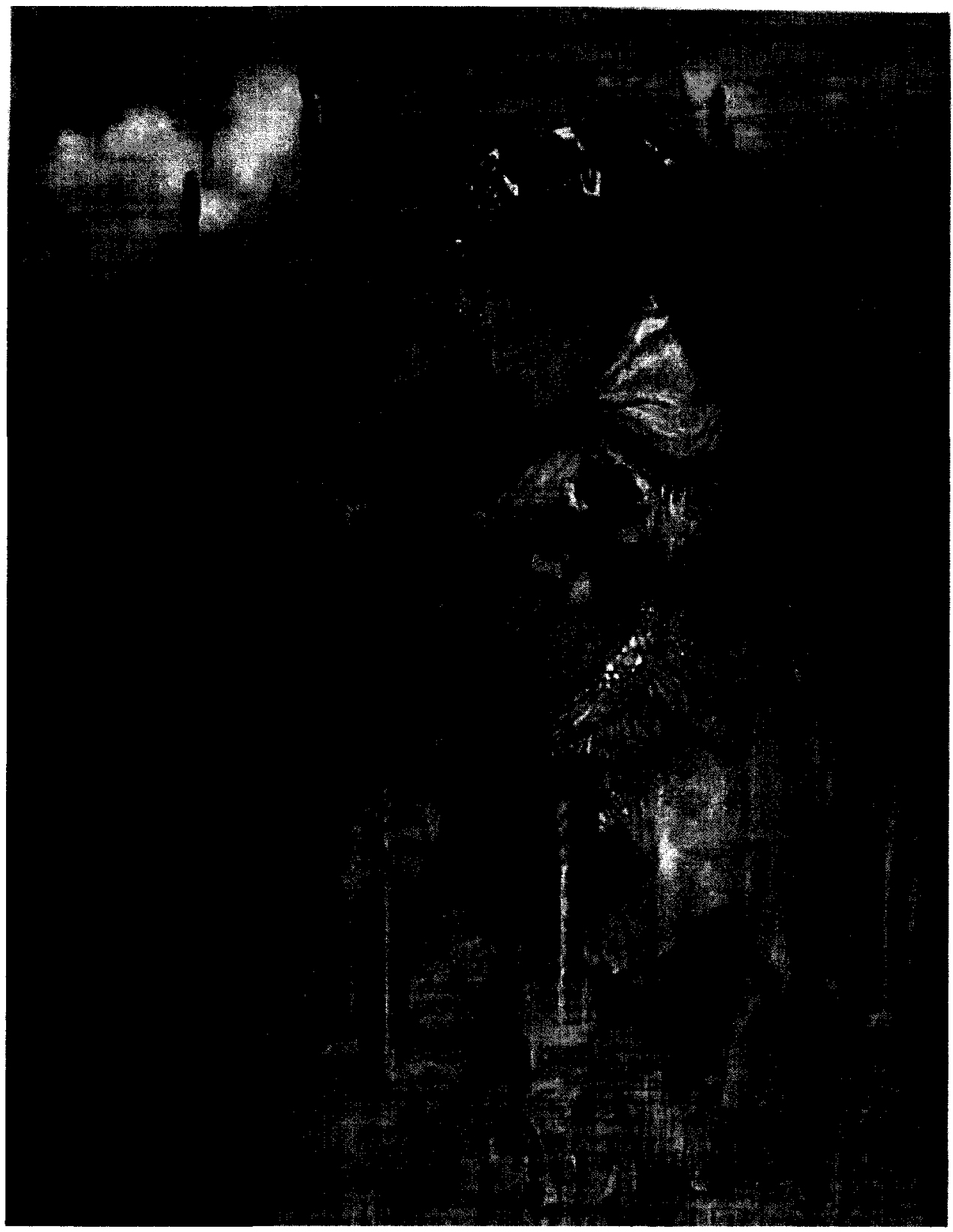

Figure 26. Gustav Mossa, Christus, 1908 (oil on canvas). 


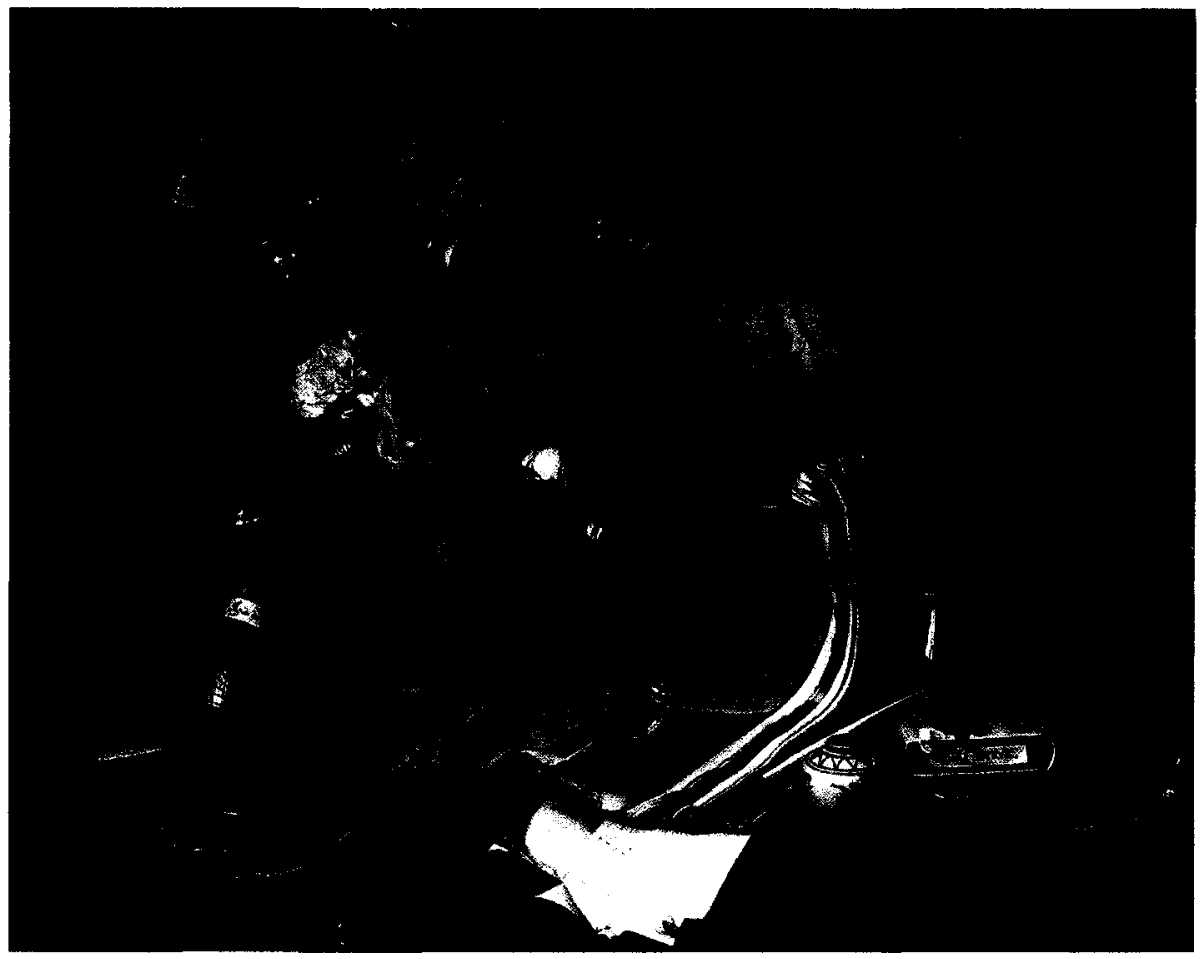

27. Maria van Oosterwyck, Vanitas Still Life, 1668 (oil on canvas).
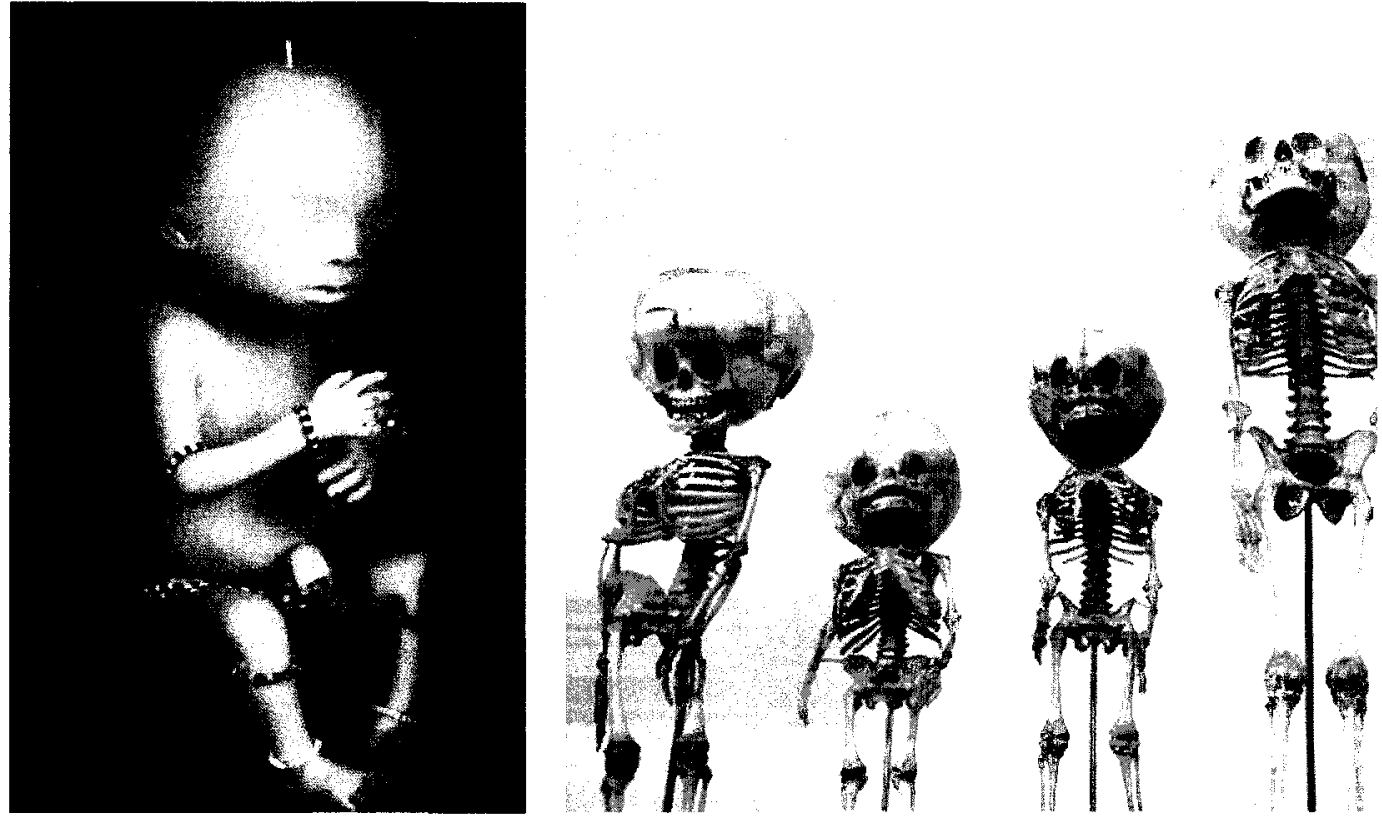

Figure 28. Preserved fetus with beads in glass jar, late-18 ${ }^{\text {th }}$ century and hydrocephalic skeletons from the Musée Dupuytren, $19^{\text {th }}$-century. 

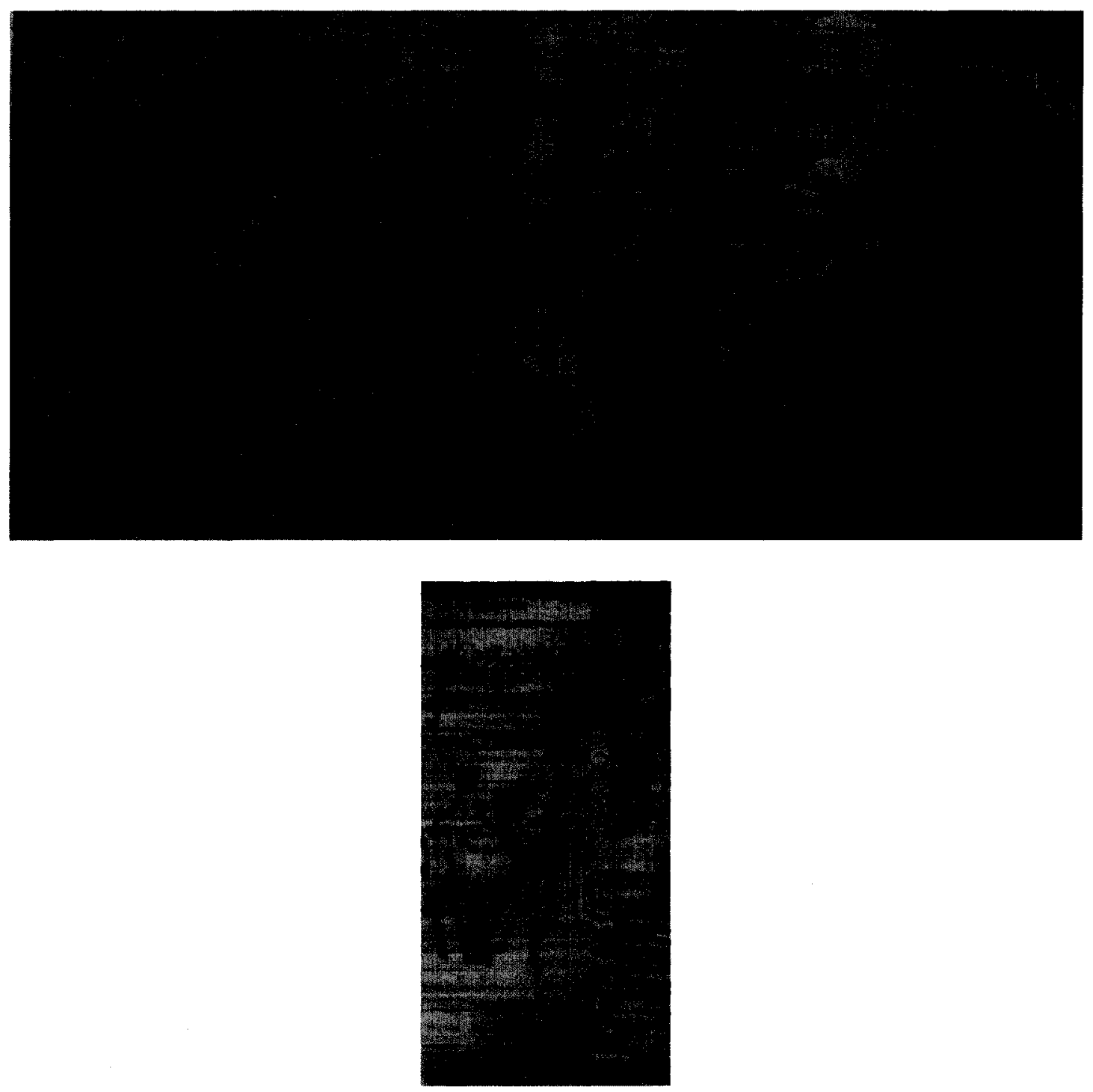

Figure 29. Gustav Mossa, La Marchande d'Amour, 1905 (watercolour); detail of Cupid. Author's photo, taken with the permission of the Musée des Beaux Arts (Jules Cheret), Nice. 


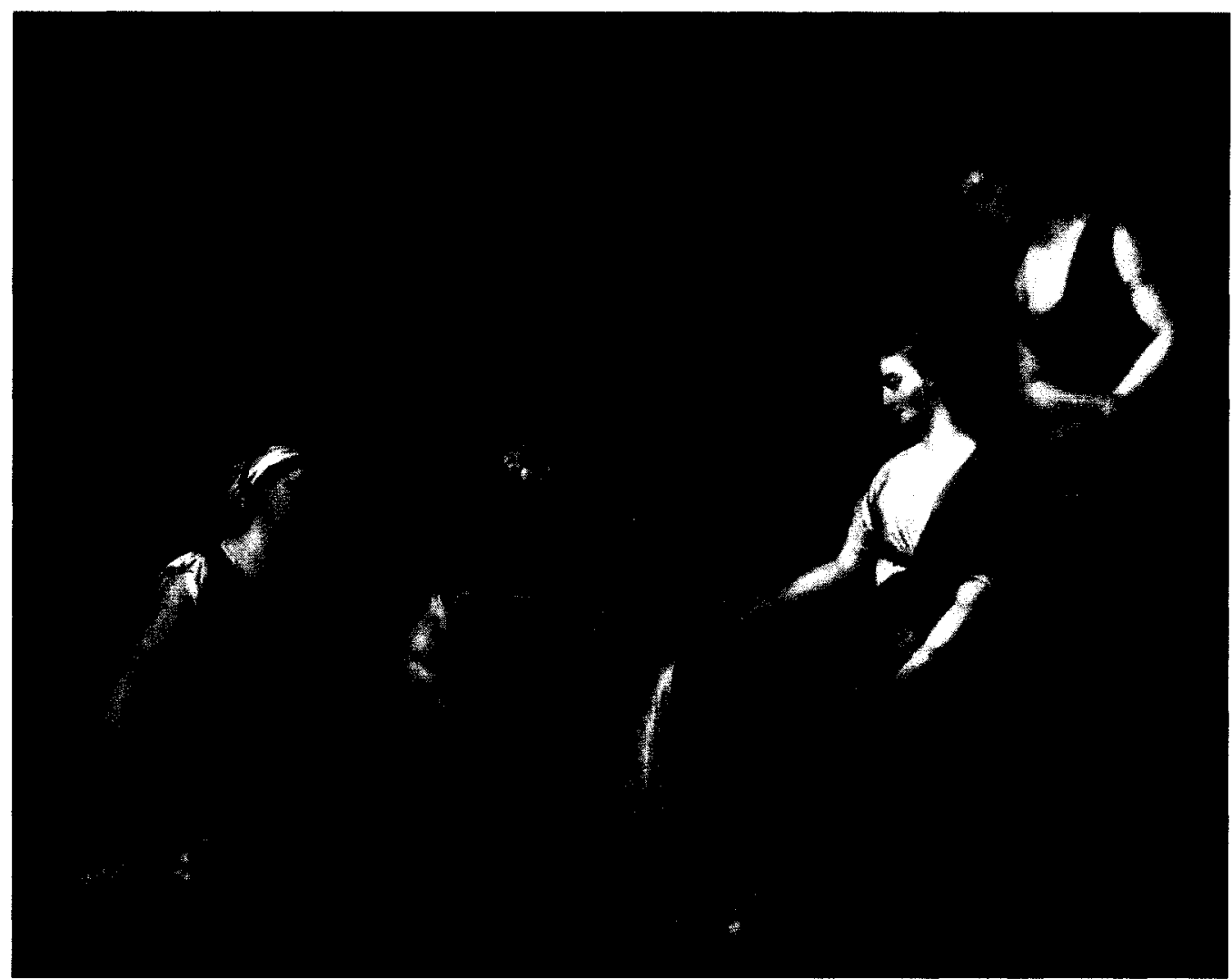

Figure 30. Joseph Vien, The Cupid Seller, 1763 (oil on canvas).

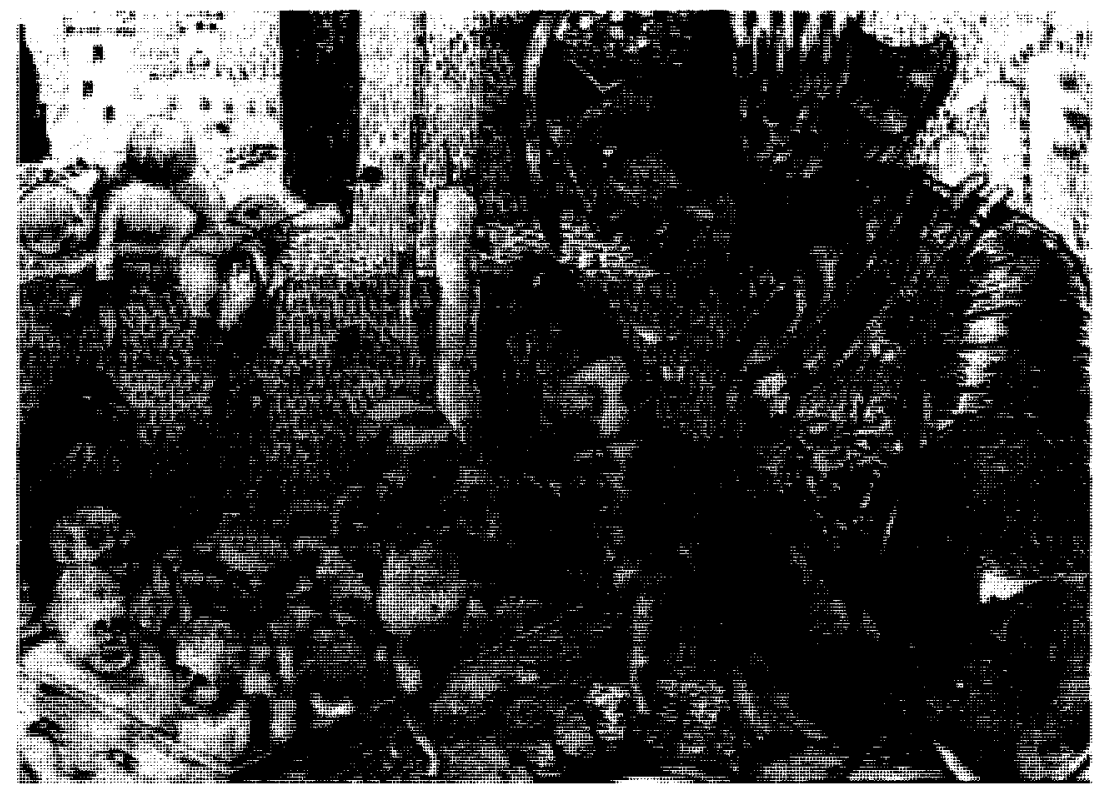

Figure 31. Gustav Mossa, Massacre of the Innocents, 1917 (watercolour). 


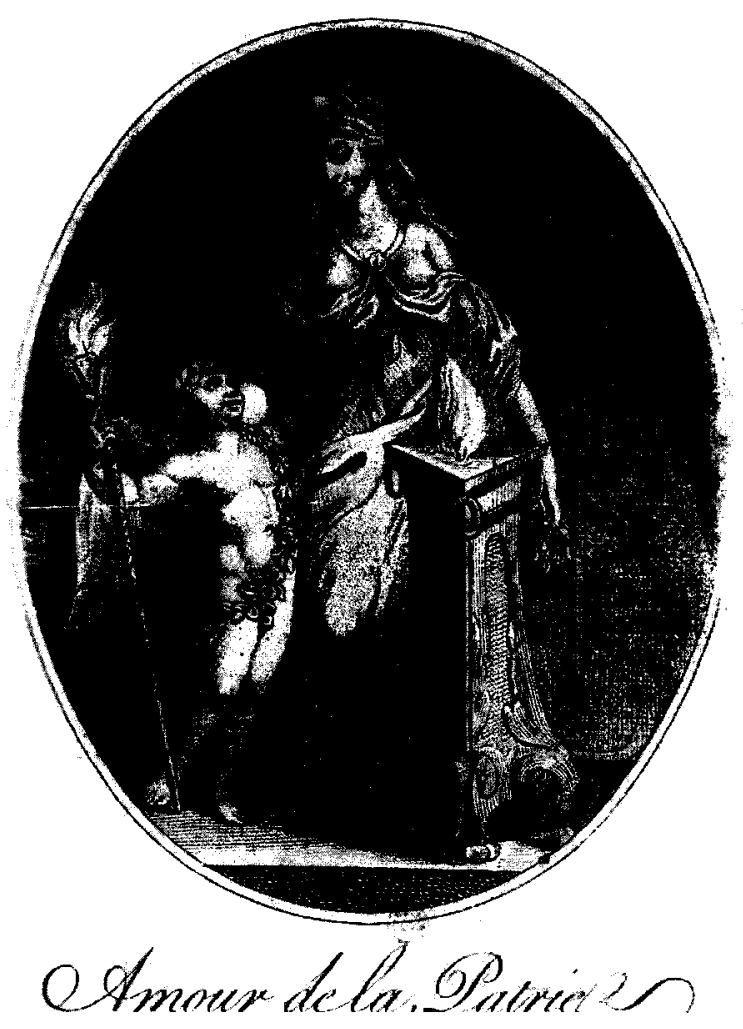

Figure 32. Anon., Love of the Fatherland, 1793.

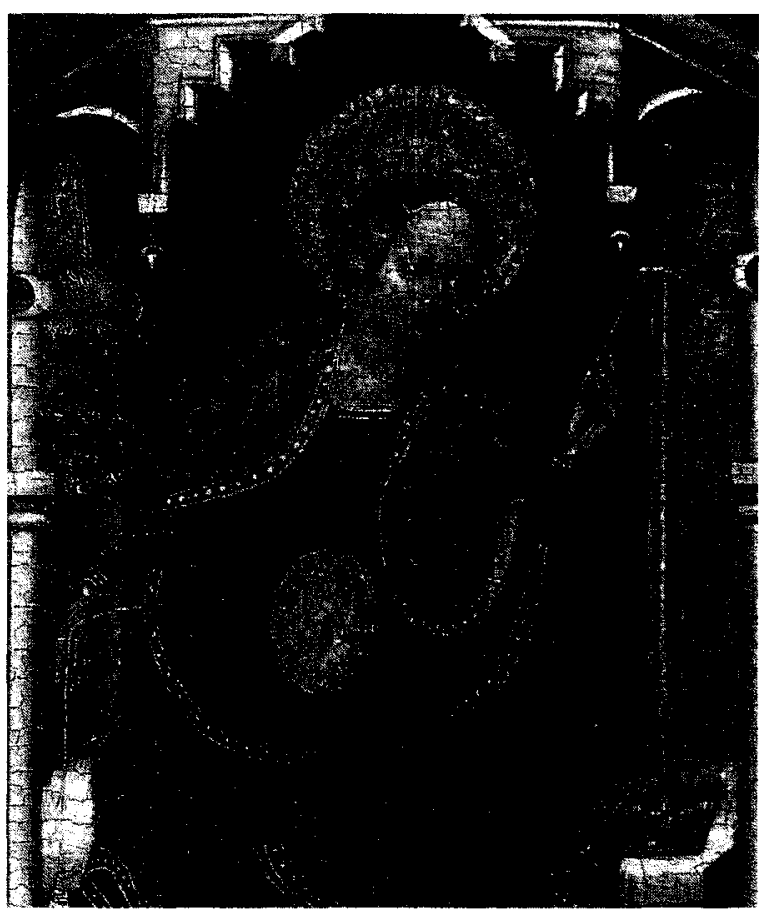

Figure 33. Anon., Maria Platytera, c. 1400. 


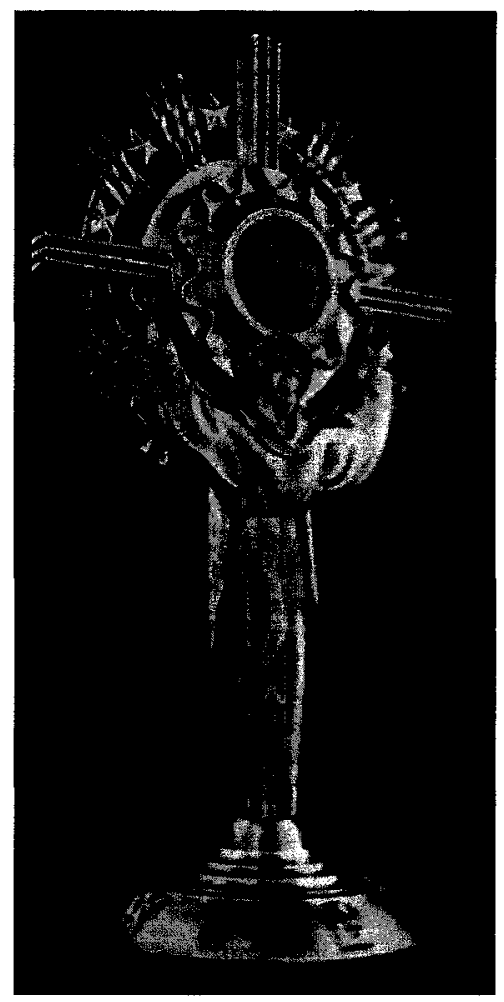

Figure 34. Monstrance with Virgin from the Church of the Immaculate Conception in France.

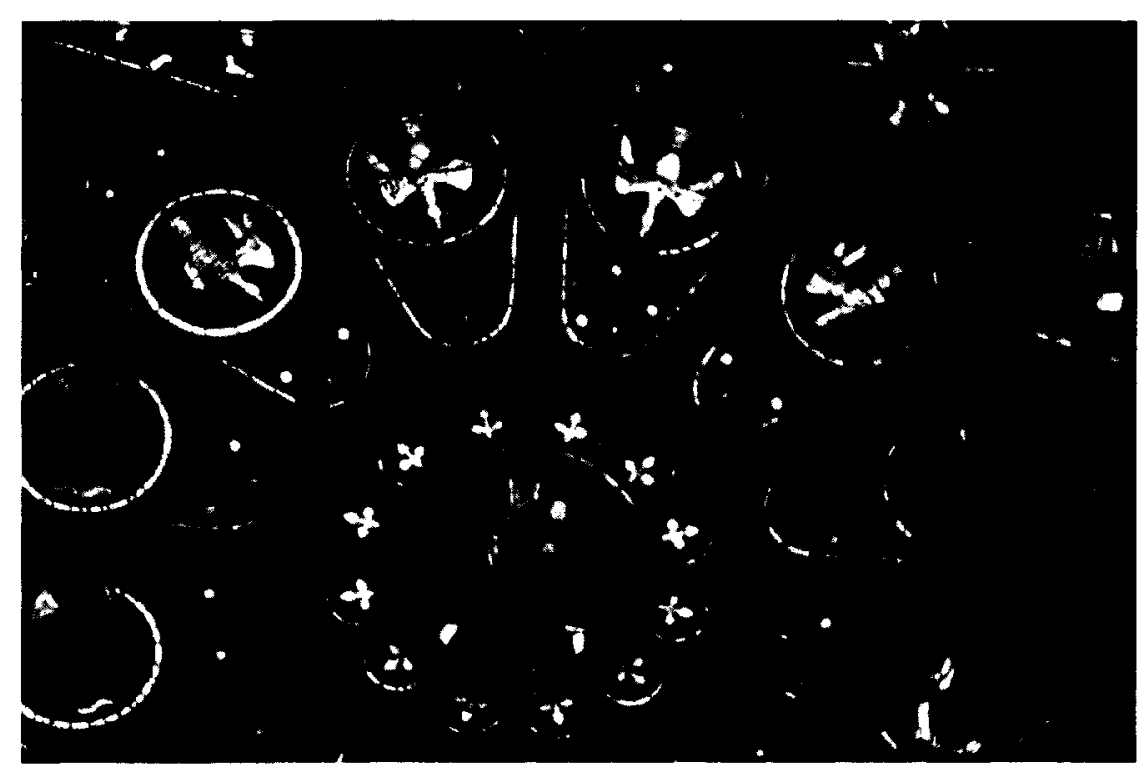

Figure 35a. Chartres Cathedral, rose window in North transept: Glorification of the Virgin, c.1235. 


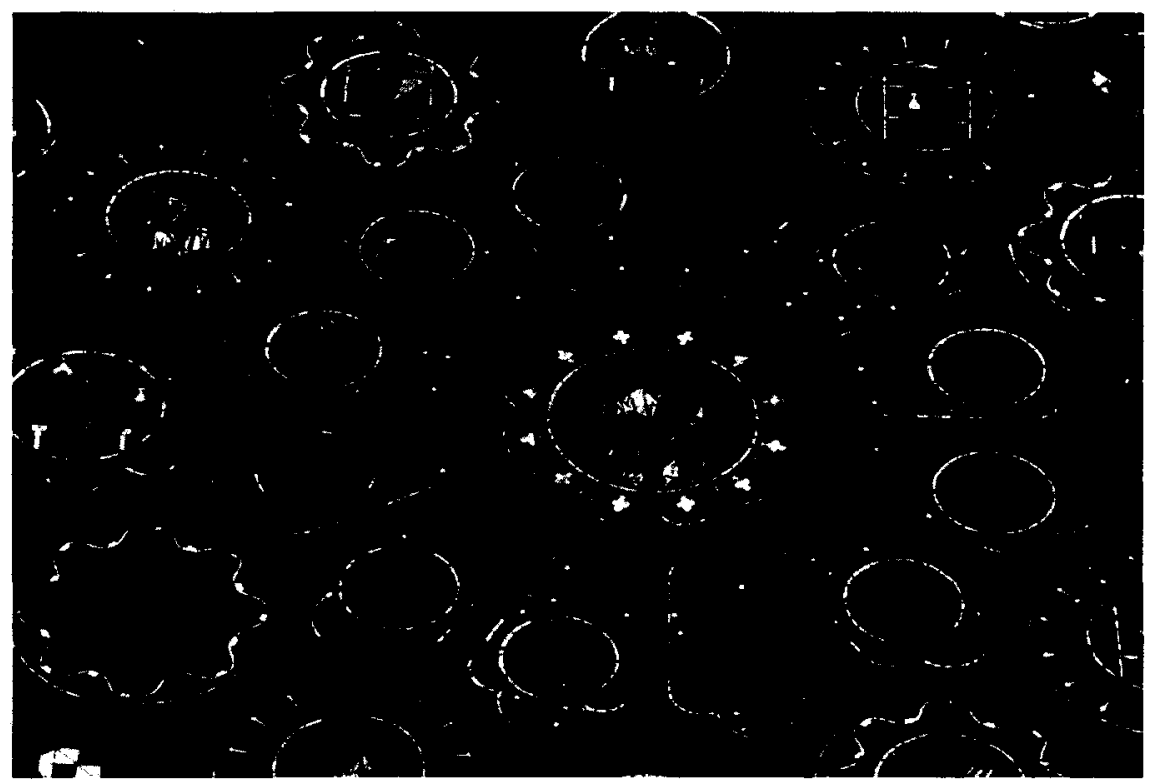

Figure 35b. Chartres Cathedral, rose window in South transept: Christ Blessing, c.1221-30.

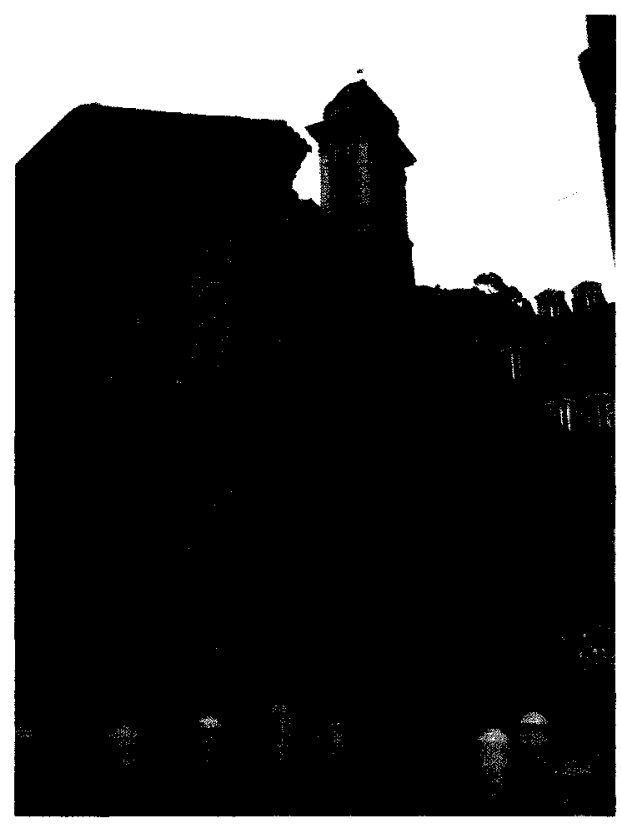

Figure 36. Exterior of the Chapelle de Saint Suaire in Nice (author's photo). 

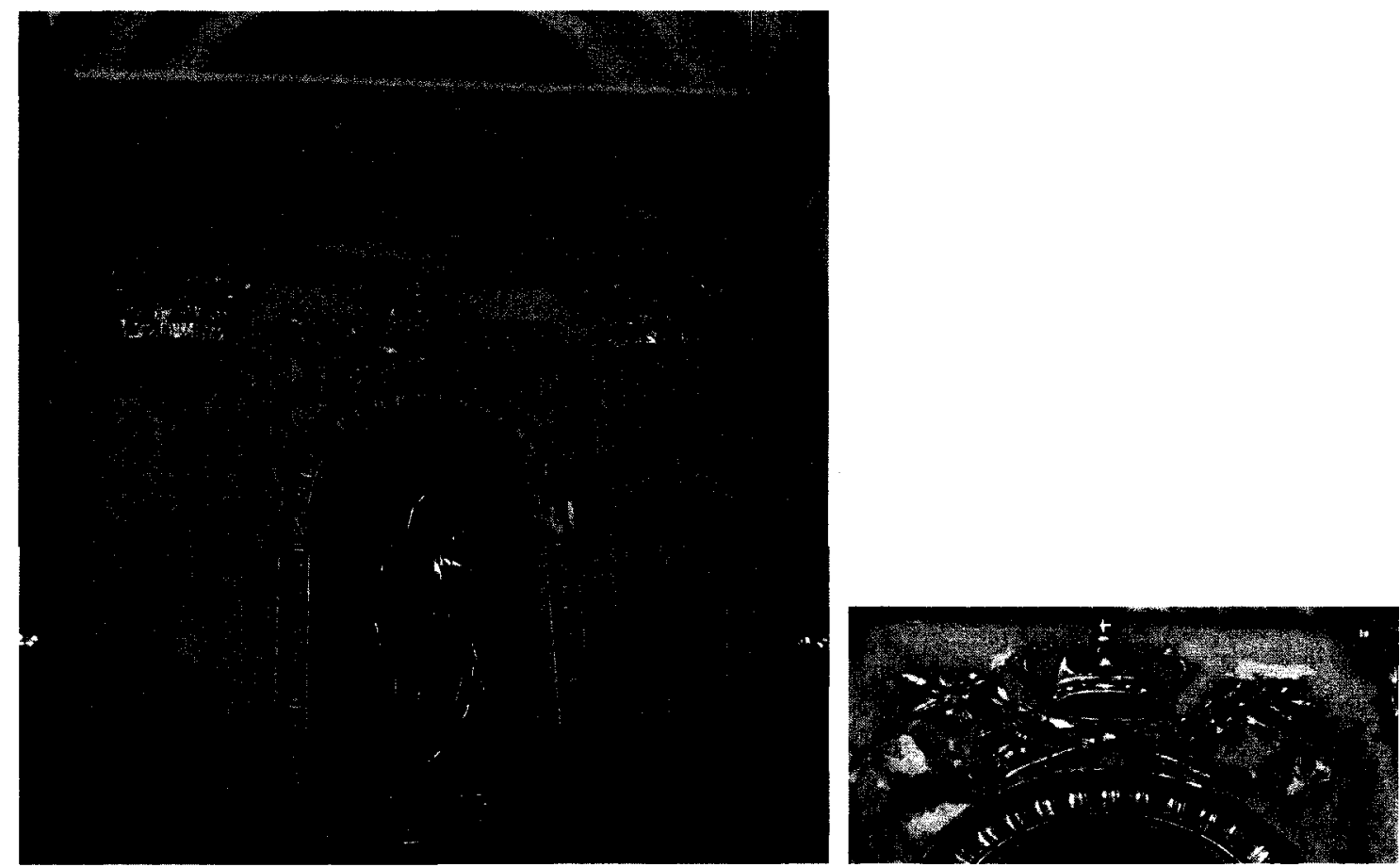

Figure 37. Statue of the Mater Expectationis in the Chapelle de Saint Suaire, Nice, late $18^{\text {th }}$ century; detail of cupids (author's photo).

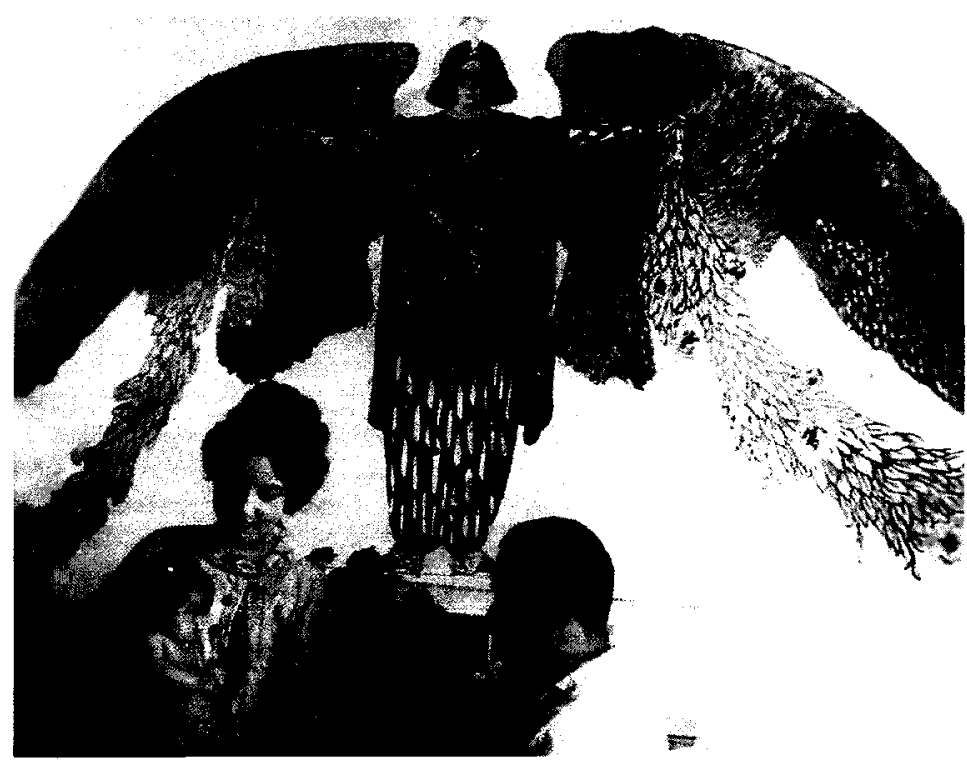

Figure 38. Photo of Mossa with wife and daughter beneath a seraph-figure that was painted by Mossa. 


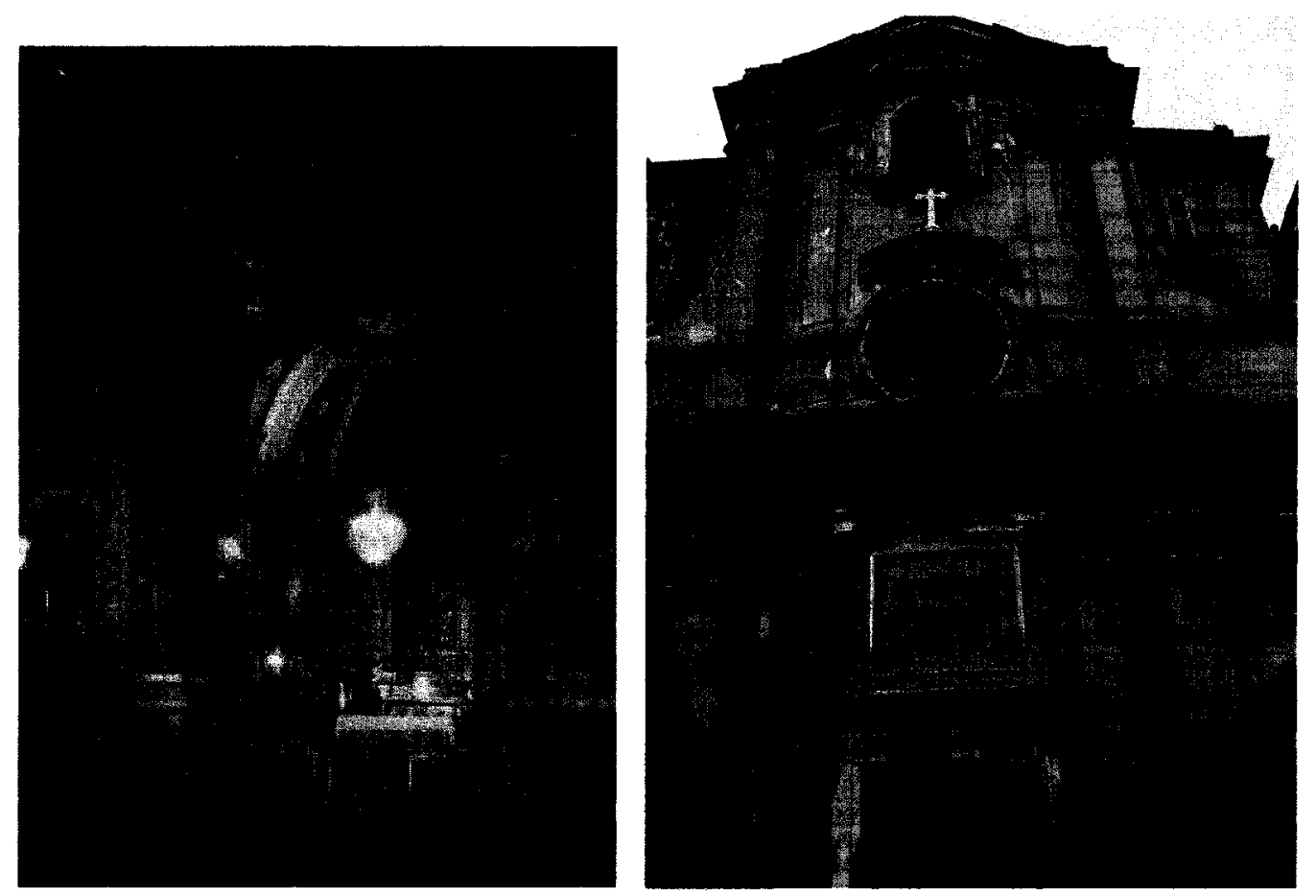

Figure 39. Interior and exterior view of the Chapelle de la Miséricorde, Nice (author's photo).

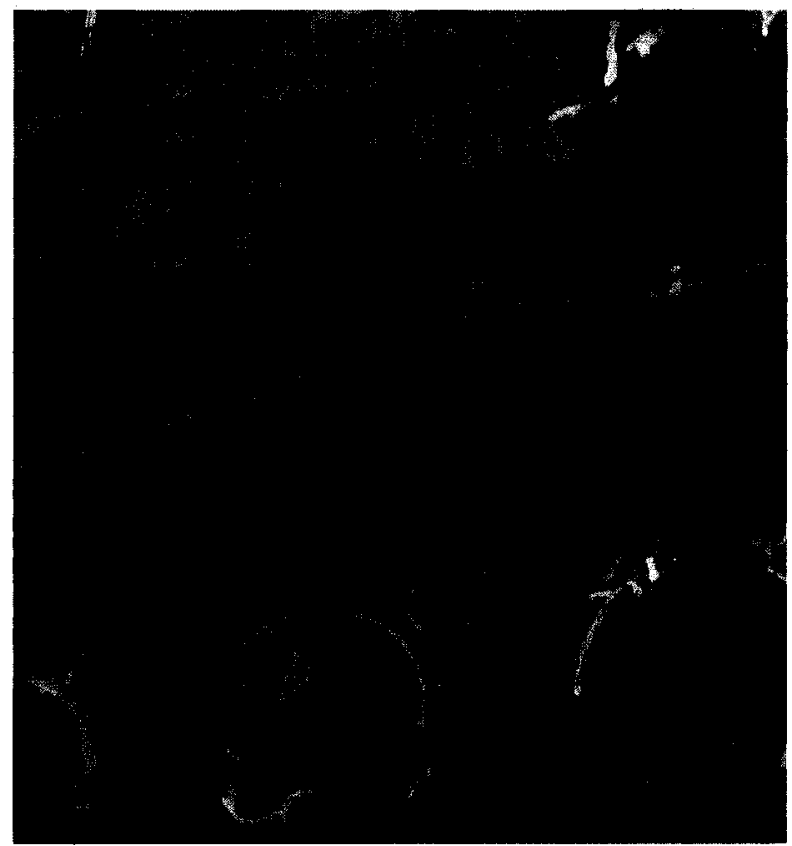

Figure 40. Rose windows in the Chapelle de la Miséricorde, Nice (author's photo). 


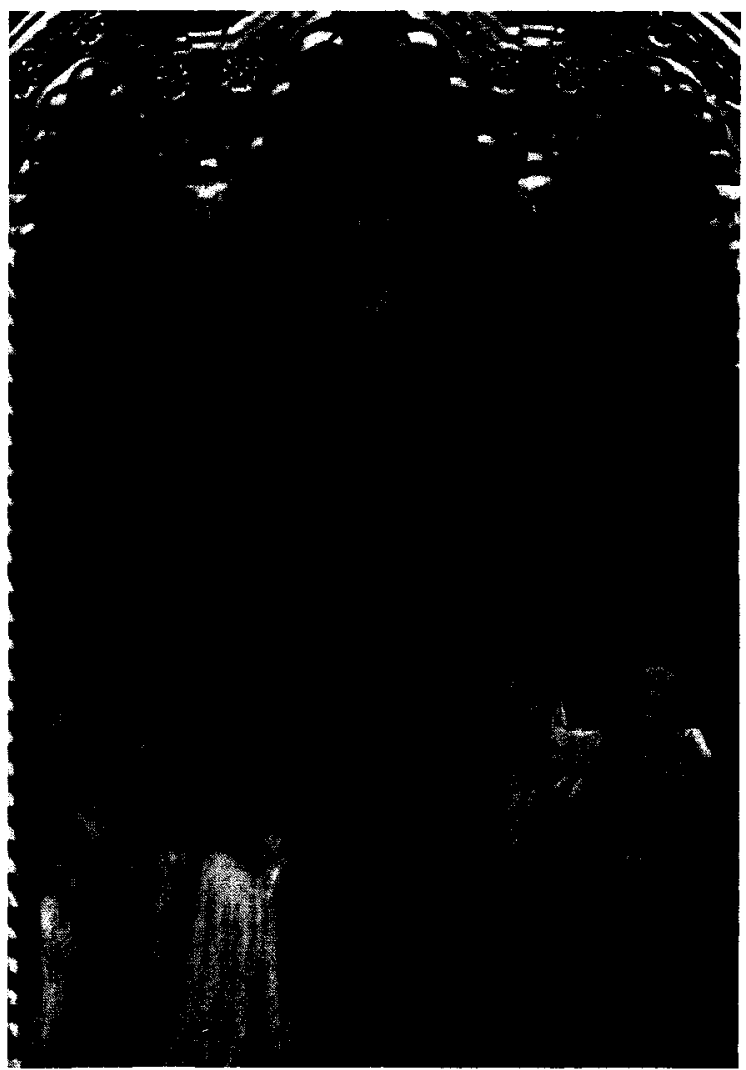

Figure 41. Jean Miralhet, La Vierge de Miséricorde (central panel), Chapelle de la Miséricorde, Nice, c.1429.

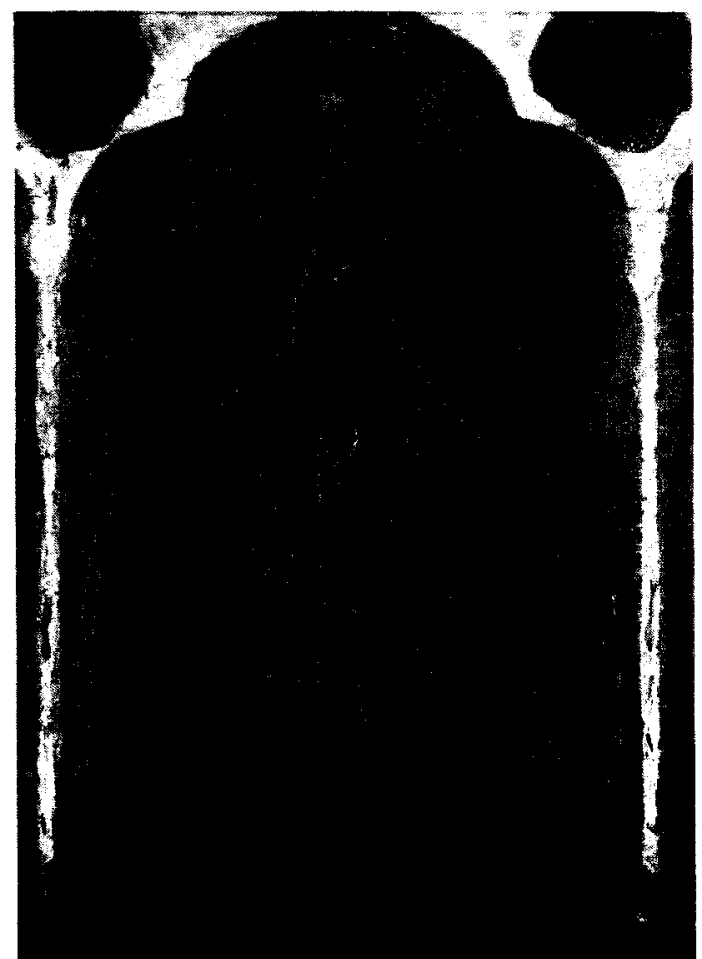

Figure 42. Jacobello Alberegno, Madonna of the Misericordia, c.1394. 


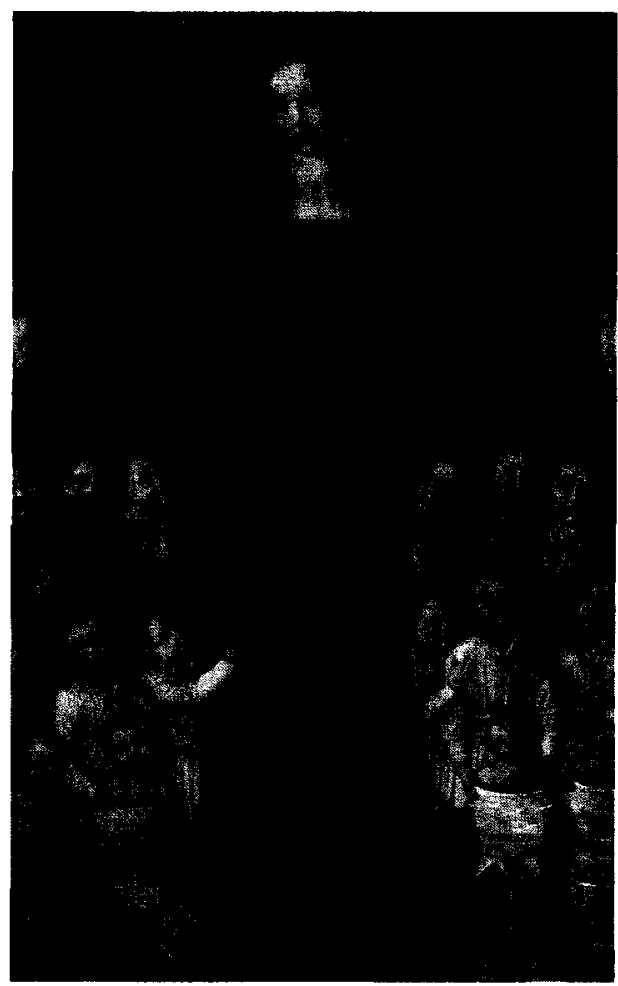

Figure 43. Francesco Granacci, Our Lady of Mercy, early $16^{\text {th }}$ century.

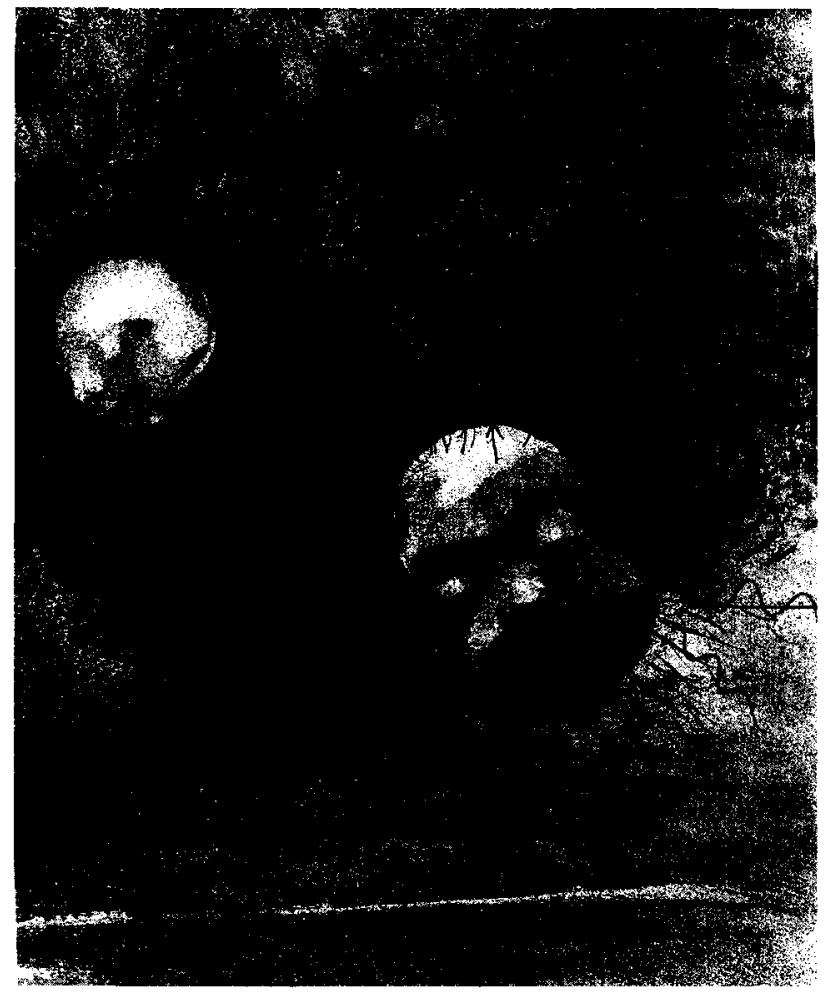

Figure 44. Odilon Redon, In the Primeval Slime, 1880 (charcoal). 


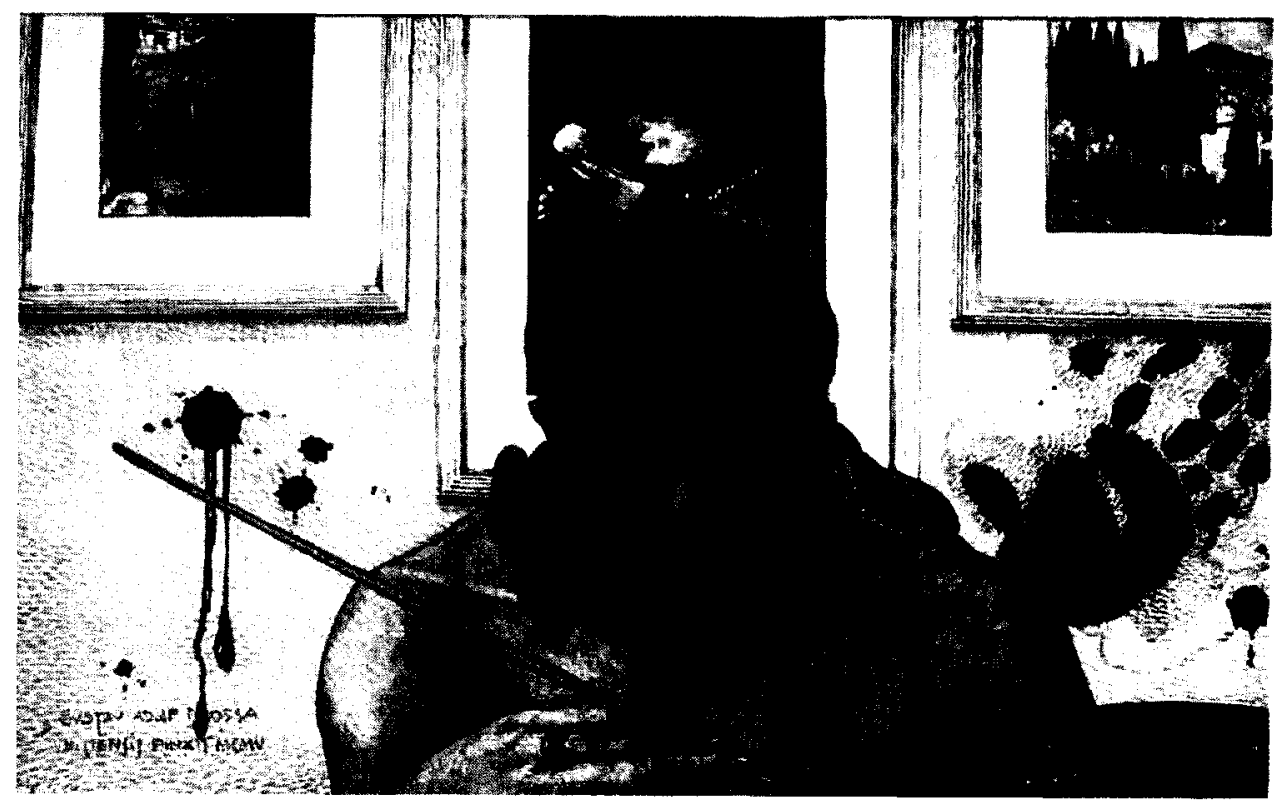

Figure 45. Gustav Mossa, Portrait Psychologique de l'Auteur, 1905 (watercolour).

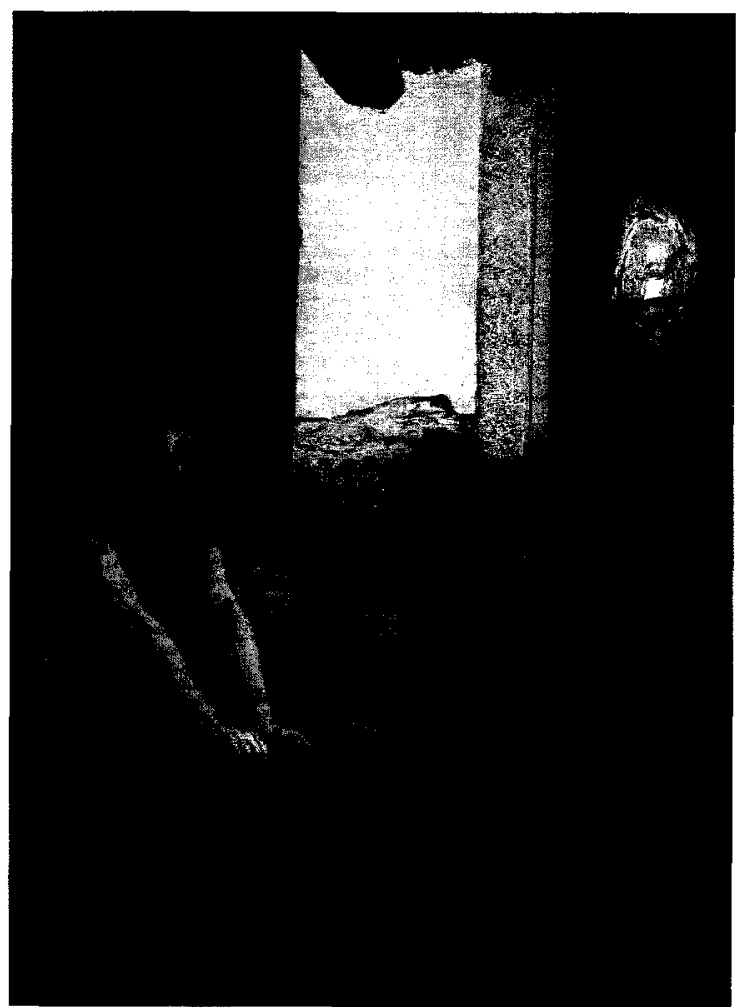

Figure 46. Max Klinger, A Love: Awakening, from Eine Liebe cycle, 1887-1903 (etching and engraving). 


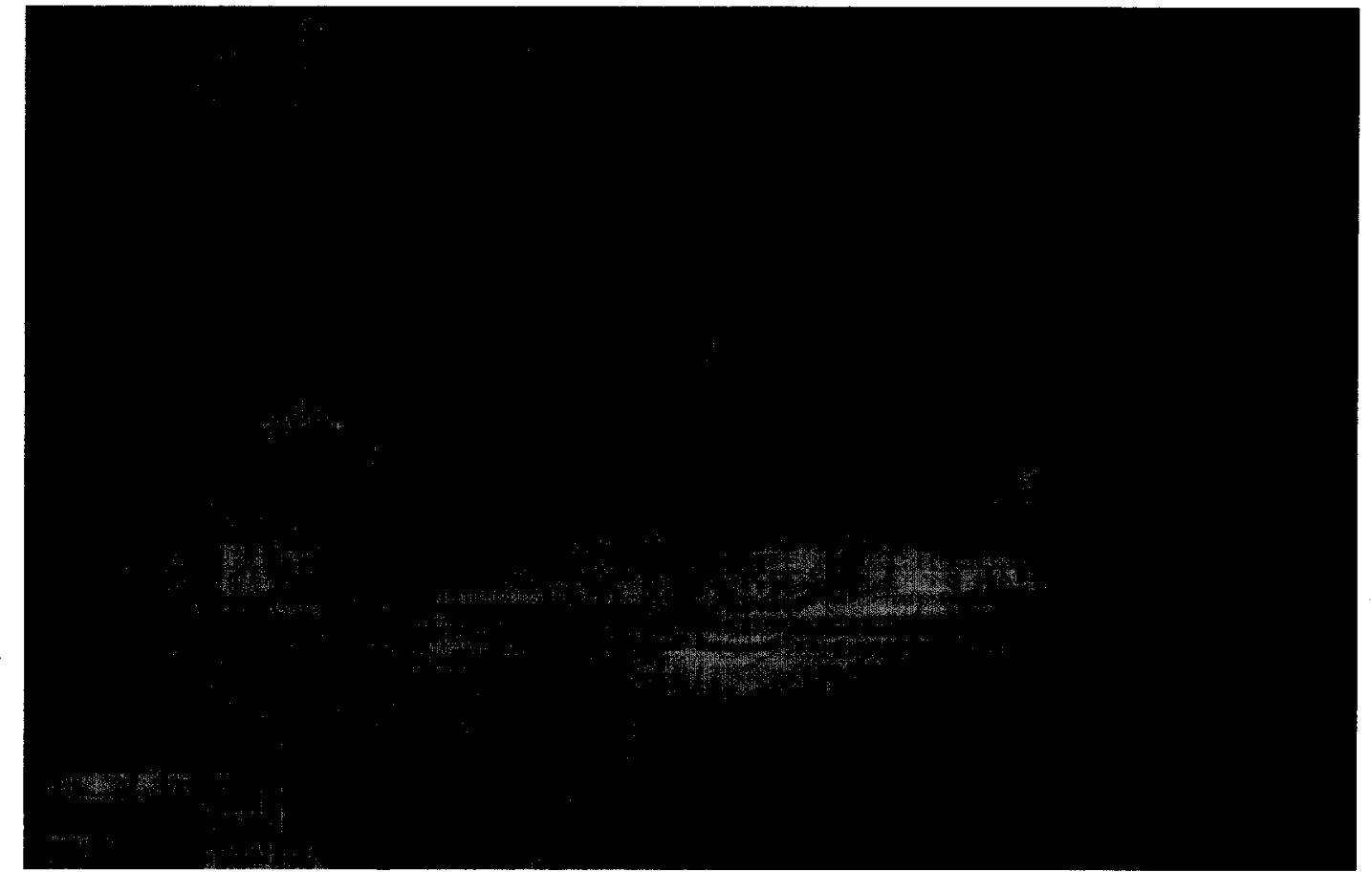

Figure 47. Max Klinger, A Love: Death, from Eine Liebe cycle, 1887-1903 (engraving and aquatint).

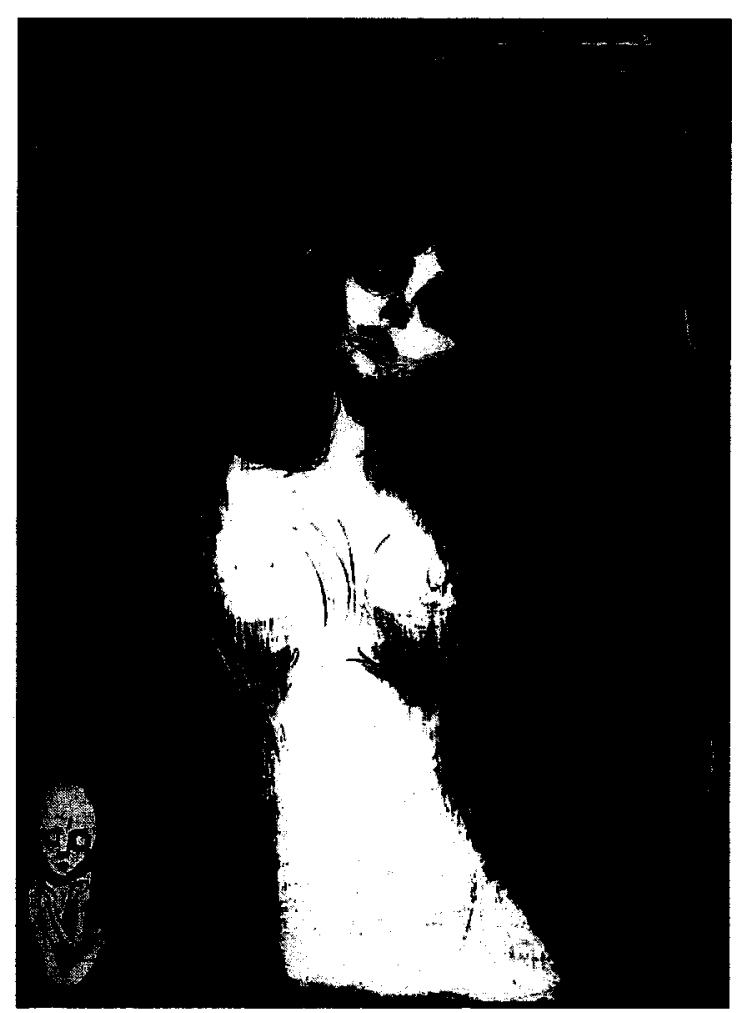

Figure 48. Edvard Munch, Madonna, c.1895-1902 (coloured lithograph). 


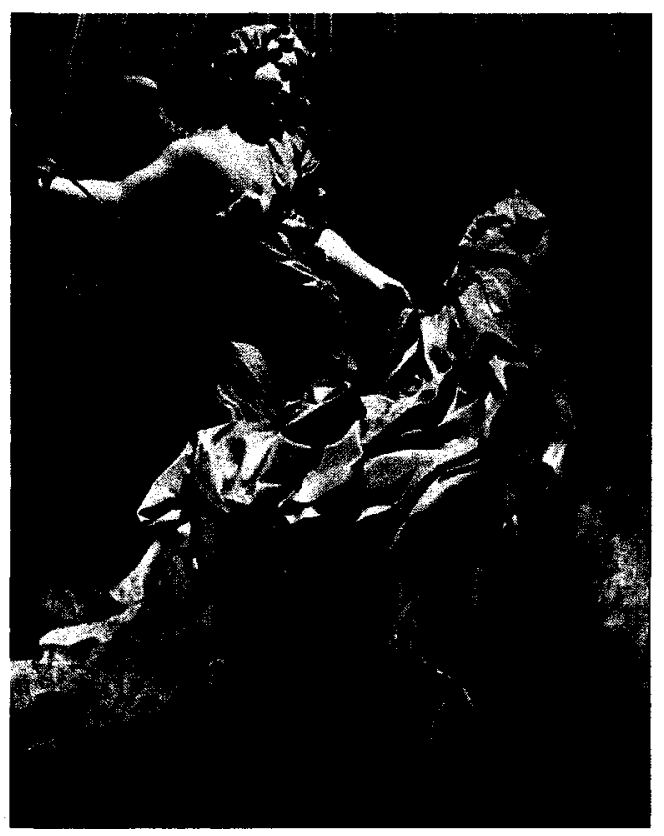

Figure 49. Giovanni Lorenzo Bernini, Ecstasy of Saint Teresa, 1652 (marble).

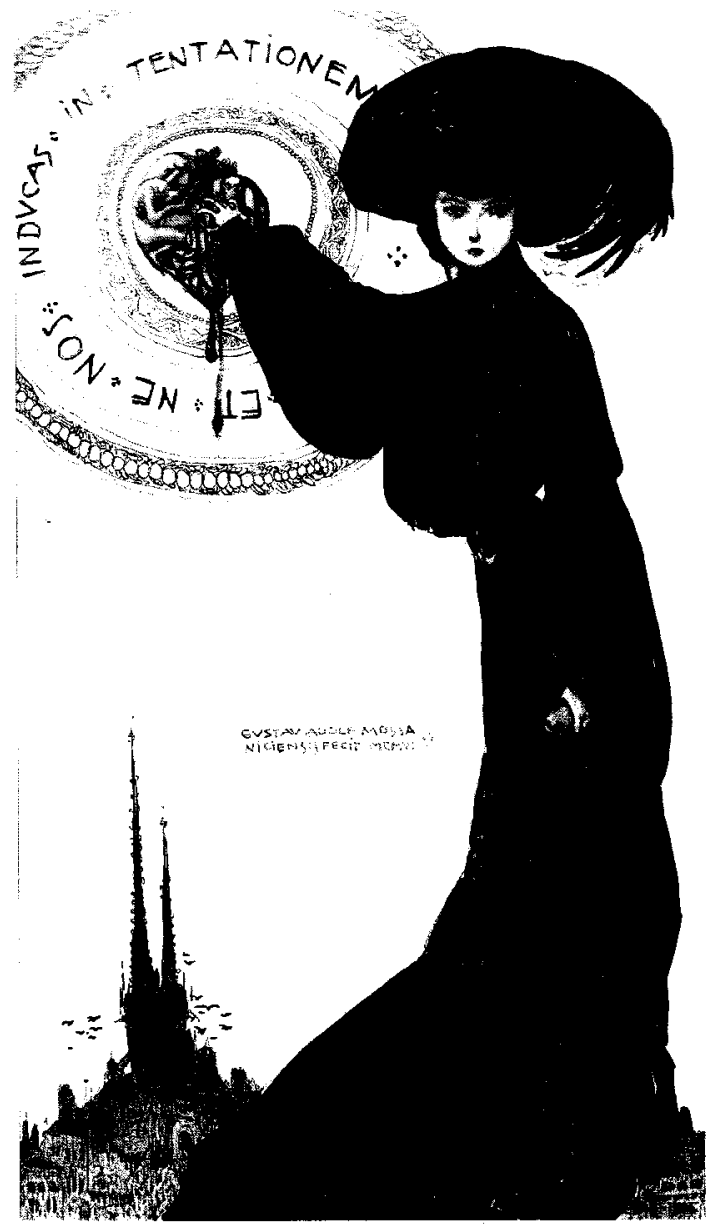

Figure 50. Gustav Mossa, Et Ne Nos Inducas in Tentationem, 1906 (watercolour). 


\section{Bibliography}

Adams, Laurie Schneider. Key Monuments of the Baroque. Boulder: Westview Press, 2000.

Aguhlon, Maurice. Marianne into Battle: Republican Imagery and Symbolism in France, 1789-1880. Cambridge and London: Cambridge University Press, 1981.

Appy, F. Pour la France: Sa repopulation et son relèvement. Nice, 1899.

Aristotle. History of Animals IV. Translated by D'Arcy Wentworth Thompson. Raleigh, N.C.: NetLibrary.

Aurevilly, Barbey de. Les Diaboliques. Translated by Ernest Boyd. New York: Knoff, 1925.

Bard, Christine, ed. Un siècle d'antiféminisme. Paris: Fayard, 1999.

Bataille, Georges. Erotism: Death and Sensuality. Translated by Mary Dalwood. New York: Walker, 1962.

Belan, Kyra. The Virgin in Art from Medieval to Modern. London: Sirrocco, 2005.

Boeckl, Christine. Images of Plague and Pestilence: Iconography and Iconology. Kirksville, MO: Truman State University Press, 2000.

Boguet, Henry. An Examen of Witches Drawn from Various Trials. Translated by Montague Summers. New York: Barnes \& Noble, 1971.

Chu, Petra ten-Doesschate. Nineteenth-Century European Art. New York: Harry N. Abrams, 2003.

Cirlot, J.E. A Dictionary of Symbols. Translated by Jack Sage. New York: Dover Publications, 2002.

Coombe, George. A System of Phrenology. Edinburgh: Anderson, 1825.

Cordulack, Shelley Wood. Edvard Munch and the Physiology of Symbolism. Fairleigh Dickinson University Press: London: Associated University Presses, 
2002.

Crary, Jonathan. Techniques of the Observer: On Vision and Modernity in the Nineteenth Century. Cambridge, Mass.: MIT Press, 1990.

Cullmann, Oscar, and F. J. Leenhardt. Essays on the Lord's Supper. Translated by J.G. Davies. Richmond: John Knox Press, 1958.

Darwin, Charles. The Descent of Man and Selection in Relation to Sex. London: Murray, 1871.

Daumier, Honoré. Intellectuelles (bas bleus) et femmes socialistes. Paris: Vilo, 1974.

Démar, Claire. "Ma loi d'avenir." In Textes sur l'affranchissement des femmes, 18321833, edited by Valentin Pelosse. Paris: Payot, 1976.

Dottin-Orsini, Mireille. "Portrait de femme: Gustave Moreau et Gustav Adolf Mossa." In Un siècle d'antiféminisme, edited by Christine Bard, 119-132. Paris: Fayard, 1999.

Douglas, Mary. Purity and Danger: An Analysis of Concepts of Pollution and Taboo. New York: Routledge, 1966.

Drumont, Edouard. La France Juive. Paris: Marpon, 1886.

Dumas, Anne. Book of Plants and Symbols. Paris: Editions du Chêne, 2000.

Feldman, David M. Birth Control in Jewish Law: Marital Relations, Contraception, and Abortion. New York: New York University Press, 1968.

Fischer, Jean-Louis. Monstres: histoire du corps et de ses défauts. Paris: Syros Alternatives, 1991.

Forneris, Jean. Gustav Adolf Mossa: l'cuuvre symboliste 1903-1918. Paris: Editions Paris-Musées, 1992.

Foucault, Michel. The Birth of the Clinic: An Archaeology of Medical Perception. Translated by Alan M. Sheridan Smith. New York: Vintage Books, 1973.

Foucault, Michel. Discipline and Punish: The Birth of the Prison. Translated by Alan M. Sheridan Smith. New York: Pantheon, 1977. 
Fowler, L.N. Marriage: Its Histories and Ceremonies; with a Phrenological and Physiological Exposition of the Functions and Qualifications for Happy Marriages. New York: Fowler \& Wells, 1854.

Fowler, O.S. Phrenology: A Practical Guide to Your Head. New York: Chelsea House, 1969.

Gaillard, Georges, ed. Rouergue Roman. La Pierre-qui-Vire: Zodiaque, 1963.

Gilman, Sander L. "Proust's Nose." Social Research 67 (Spring 2000): 61-79.

Gonnard, René. La depopulation en France. Lyon, 1898.

Grosz, Elizabeth. Volatile Bodies: Toward a Corporeal Feminism. Bloomington: Indiana University Press, 1994.

Gould, George M., and Walter L. Pyle. Anomalies and Curiosities of Medicine. New York: Julian Press, 1896.

Hall, James. Dictionary of Subjects and Symbols in Art. Boulder: Westview Press, 2008.

Hansen, Eric. Disaffection and Decadence: A Crisis in French Intellectual Thought, 1848-1898. Washington, D.C.: University Press of America, 1982.

Hanson, Ann Ellis. "Hippocrates: Diseases of Women I." Signs 1, no. 2 (Winter 1975): 567-584.

Hufeland, C.W. Some Account of Dr. Gall's New Theory of Physiognomy. London: Longman, 1807.

Hunt, David. Parents and Children in History: The Psychology of Family Life in Early Modern France. New York: Basic Books, 1970.

Hunt, Marie-Hélène. Monstrous Imagination. Cambridge, Mass.: Harvard University Press, 1993.

Huysmans, Joris-Karl. L'Art Moderne. Paris: G. Charpentier,1883.

Huysmans, Joris-Karl. Down There. Translated by Keene Wallace. New York: 
Dover Publications, 1973.

Jaucourt, Louis de. "Fausse Couche." In Encyclopédie méthodique. Vol. 145. Paris: Panckoucke, 1789.

Johnson, Paul. A History of the Jews. London: George Weidenfeld \& Nicolson, 1987.

Katz, Melissa R. "Regarding Mary: Women’s Lives Reflected in the Virgin's Image." In Divine Mirrors: The Virgin Mary in the Visual Arts, edited by Melissa Katz. New York: Oxford University Press, 2001.

Kemp, Martin. "A Perfect and Faithful Record: Mind and Body in Medical Photography before 1900." In Beauty of Another Order: Photography in Science, edited by Ann Thomas, 120-149. New Haven, CT: Yale University Press in association with the National Gallery of Canada, Ottawa, 1997.

Keown, J. Abortion, Doctors and the Law. Cambridge: Cambridge University Press, 1988.

Knight, Richard Payne, and Thomas Wright. Sexual Symbolism: A History of Phallic Worship. New York: Julian Press, 1957.

Kristeva, Julia. Powers of Horror: An Essay on Abjection. Translated by Leon Roudiez. New York: Colombia University Press, 1982.

Kukla, Rebecca. Mass Hysteria: Medicine, Culture and Mothers' Bodies. Lanham: Toronto: Rowman \& Littlefield, 2005.

Lafon, Sylvie, and Anne-Marie Clais. Gustav Adolf Mossa: La scène symboliste. Nice: Z'éditions, 1993.

Landes, Joan B. Visualizing the Nation: Gender, Representation, and Revolution in Eighteenth-Century France. Ithaca: Cornell University Press, 2001.

Lapouge, G. Vacher de, and Karen Offen. "Depopulation, Nationalism and Feminism in Fin-de-Siècle France." American Historical Review 89 (1984): 648-676.

Laqueur, Thomas Walter. Making Sex: Body and Gender from the Greeks to Freud. Cambridge, Mass.: Harvard University Press, 1990.

Larson, Barbara. The Dark Side of Nature: Science, Society, and the Fantastic in the 
Work of Odilon Redon. University Park, P.A.: Pennsylvania State University, 2005.

Larson, Barbara. "Evolution and Degeneration in the Early Works of Odilon Redon." Nineteenth-Century Art Worldwide 2, no.2 (Spring 2003), http://19thc-artworldwide.org/.

Latham, Melanie. Regulating Reproduction: A Century of Conflict in Britain and France. Manchester, UK.; New York: Manchester University Press, 2002.

Lavater, Johann Caspar. Essays on Physiognomy: For the Promotion of the Knowledge and the Love of Mankind. Translated by Thomas Holcroft. London: C. Whittingham, 1804.

Le Bon, Gustave. Les lois physiologiques de l'évolution des peuples. New York: Arno Press, 1974.

Levasseur, Emile. La population française. 3 vols. Paris: Rousseau, 1889-1892.

MacDonald, Helen. Human Remains: Dissection and its Histories. London: Yale University Press, 2006.

McClintock, Ann. "Family Feuds: Gender, Nationalism and Family." Feminist Review, 44 (Summer 1993): 62-79.

McCormick, Leander Hamilton. Characterology. Chicago: Rand McNally, 1920.

McLaren, Angus. Sexuality and Social Order: The Debate over the Fertility of Women and Workers in France 1770-1920. London: New York: Holmes \& Meier Publishers, 1983.

McTavish, Lianne. Childbirth and the Displays of Authority in Early Modern France. Burlington: Ashgate Publishing, 2005.

Meiss, Millard. Painting in Florence and Siena After the Black Death. New York: Harper, 1951.

Menon, Elizabeth K. Evil by Design: The Creation and Marketing of the Femme Fatale. Urbana: University of Illinois Press, 2006.

Michelet, Jules. L'Amour. Paris: Hachette, 1858. 
Michelet, Jules. La Femme. Paris: Hachette, 1860.

Michelet, Jules. La Sorcière. Vol. 1. Bruxelles A. Lacroix: Verboeckhoven,1863.

Morton, Marsha, "Impulses and Desires: Klinger's Darwinism in Nature and Society." Nineteenth-Century Art Worldwide 2, no.2 (Spring 2003), http://19thc-artworldwide.org/.

Mossa, Gustav. "Les Arts." In Centenaire du rattachement de Nice. Edited by Camille Cappatti, 121-128. Nice: Meyerbeer, 1960.

Mosse, George L. The Image of Man: The Creation of Modern Masculinity. New York: Oxford University Press, 1996.

Mosse, George L. Toward the Final Solution: A History of European Racism. New York: Harper \& Row, 1978.

Nordau, Max. Degeneration. Lincoln : University of Nebraska Press, 1993.

Oakley, Ann. The Captured Womb: A History of the Medical Care of Pregnant Women. New York: Blackwell Publishing, 1984.

Paré, Ambroise. On Monsters and Marvels. Translated by Janis L. Pallister. Chicago: University of Chicago Press, 1982.

Pedersen, Jean Elisabeth. Legislating the French Family: Feminism, Theater, and Republican Politics, 1870-1920. New Brunswick, N.J.: Rutgers University Press, 2003.

Pender, Stephen. "In the Bodyshop: Human Exhibition in Early Modern England." 'Defects': Engendering the Modern Body. Michigan: University of Michigan Press, 2000.

Plato. Timaeus. Translated by Desmond Lee. London: Penguin Books, 1977.

Rendall, Jane. The Origins of Modern Feminism: Women in Britain, France and the United States 1780-1860. Basingstoke: Macmillan, 1985.

Riddle, John. Eve's Herbs: A History of Contraception and Abortion in the West. Cambridge, Mass.: Harvard University Press, 1997. 
Robbins, Rossell Hope. Encyclopedia of Witchcraft and Demonology. New York: Crown Publishers, 1959.

Rousseau, Jean-Jacques. Emile. Translated by Barbara Foxley. London: New York: Aldine Press, 1963.

Saint-Simon, Henri comte de. La physiologie sociale. Paris: Presses universitaires de France, 1965.

Scarry, Elaine. The Body in Pain: The Making and Unmaking of the World. New York: Oxford University Press, 1985.

Schloesser, Stephen. "From Spiritual Naturalism to Psychical Naturalism: Catholic Decadence, Lutheran Munch, Madone Mystérique." In Edvard Munch: Psyche, Symbol and Expression, edited by Jeffery Howe, 75-110. Chestnut Hill, M.A.: McMullen Museum of Art, Boston College, 2001.

Silverman, Debora. Art Nouveau in Fin-de-Siècle France: Politics, Psychology, and Style. Berkeley: University of California Press, 1989.

Silverman, Debora. "Nature, Nobility, and Neurology: The Ideological Origins of Art Nouveau in France, 1889-1900." PhD diss., Princeton University, 1983.

Smith, Bonnie. Ladies of the Leisure Class: The Bourgeoisies of Northern France in the Nineteenth Century. New Jersey: Princeton University Press, 1981.

Soubiran, Jean-Roger. Gustav Adolf Mossa 1883-1971. Nice: Editions Ediriviera \& Alligator, 1985.

Spengler, Joseph J. France Faces Depopulation. Durham, N.C.: Duke University Press, 1979.

Sprenger, Jacobus, and Heinrich Kramer. Malleus Maleficarum: The Hammer of Witchcraft. Translated by Montague Summers. London: Folio Society, 1968.

Stafford, Barbara. Body Criticism: Imaging the Unseen in Enlightenment Art and Medicine. Cambridge, Mass.: MIT Press, 1991.

Taine, Hippolyte. Les origines de la France contemporaine. Vol. 1. Paris: Hachette, 1896. 
Thurston, Herbert, "Ostensorium (Monstrance)." In The Catholic Encyclopedia. Edited by Charles G. Herbermann et al. New York: Robert Appleton Company, 1907-12, http://www.newadvent.org/cathen/11344a.htm.

Tissot, Simon-André. L'Onanisme. New York: Collins \& Hannay, 1832.

Van der Toorn, Karel, Bob Becking, and Pieter W. van der Horst. Dictionary of Deities and Demons in the Bible. Grand Rapids, Mich.: Eerdmans, 1999.

Varnedoe, J. Kirk T. Graphic Works of Max Klinger. New York: Dover Publications, 1977.

Verdon, Timothy. Mary in Western Art. New York: Pope John Paul II Cultural Center, 2005.

Vloberg, Maurice. L'Eucharistie dans l'art. Grenoble: B. Arthaud, 1946.

Walker, Barbara. The Woman's Dictionary of Symbols and Sacred Objects. San Francisco: Harper \& Row, 1988.

Wilson, Adrian. The Making of Man-Midwifery: Childbirth in England 1660-1770. Cambridge, Mass.: Harvard University Press, 1995. 